TOTAL WATER WITHDRAWALS IN MISSISSIPPI, 1990

By Penny M. Johnson

U.S. GEOLOGICAL SURVEY

Open-File Report 93-375

Prepared in cooperation with the

MISSISSIPPI DEPARTMENT OF ENVIRONMENTAL QUALITY

Office of Land and Water Resources

Jackson, Mississippi

1994 
U.S. DEPARTMENT OF THE INTERIOR BRUCE BABBITT, Secretary

U.S. GEOLOGICAL SURVEY

Robert M. Hirsch, Acting Director

For additional information write to:

District Chief

U.S. Geological Survey Suite 710, Federal Building 100 West Capitol Street Jackson, Mississippi 39269
Copies of this report can be purchased from:

U.S. Geological Survey Earth Science Information Center Open-File Reports Section Box 25286, MS 517, Federal Center Denver, Colorado 80225 


\section{CONTENTS}

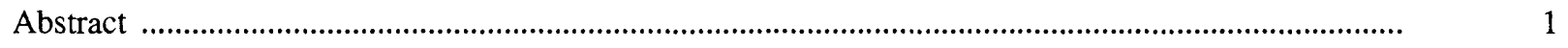

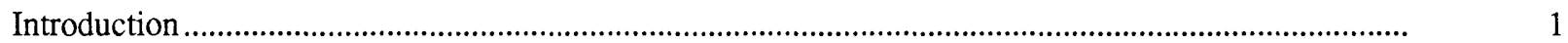

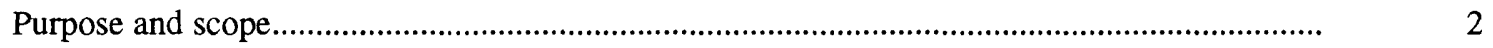

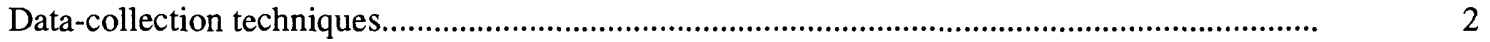

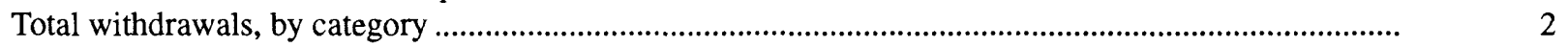

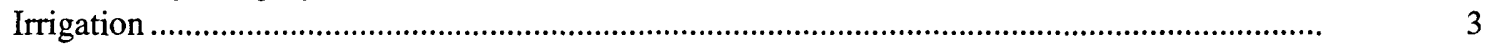

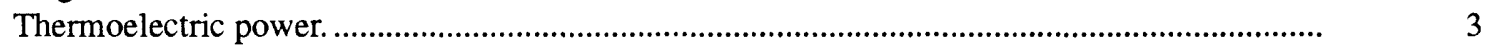

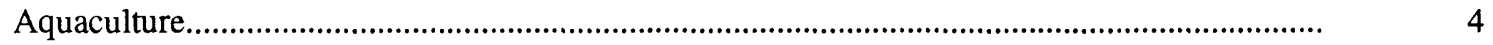

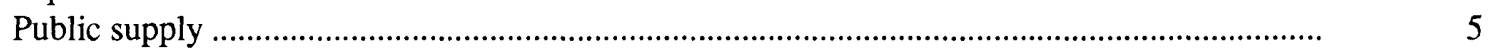

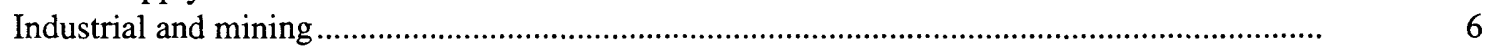

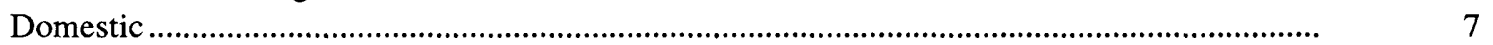

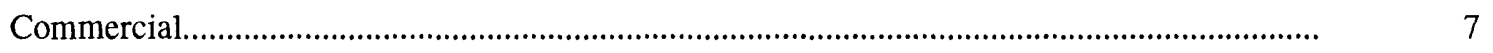

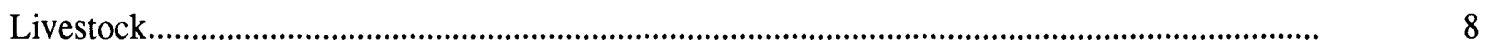

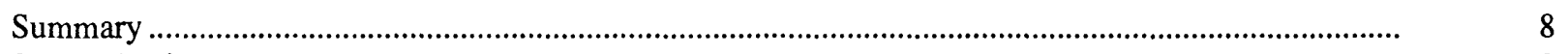

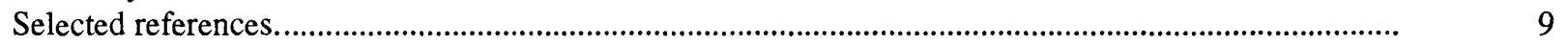

\section{ILLUSTRATIONS}

Figure 1. Pie charts showing total withdrawals in Mississippi, by category of use, $1990 \ldots \ldots \ldots \ldots \ldots \ldots . . . \ldots . . .11$

2. Diagrams showing total withdrawals for all offstream water-use categories in Mississippi, by county and source, 1990

3. Chart showing total withdrawals in Mississippi, by source, 1960-90

4. Chart showing total withdrawals for major categories in Mississippi, 1960-90..................... 14

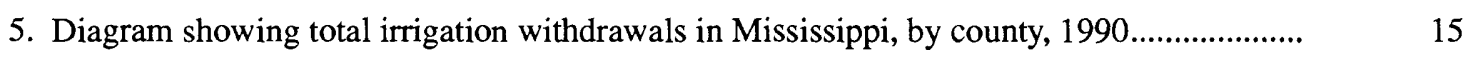

6. Chart showing total irrigation withdrawals in Mississippi, by source and acres irrigated, 1960-90

7. Diagram showing total thermoelectric power withdrawals in Mississippi, by county, 1990

8. Chart showing total thermoelectric power withdrawals in Mississippi, by source, 1960-90

9. Diagram showing total aquaculture withdrawals in Mississippi, by county, 1990

10. Chart showing total aquaculture withdrawals in Mississippi, by source, 1970-90................ 20

11. Diagram showing total public-supply withdrawals in Mississippi, by county, $1990 \ldots \ldots \ldots \ldots . . . . . \quad 21$

12. Chart showing total public-supply withdrawals in Mississippi, by source, 1960-90 ............ 22 


\section{ILLUSTRATIONS--Continued}

Figure 13. Diagram showing total industrial and mining withdrawals in Mississippi, by county, 1990

14. Chart showing total industrial and mining withdrawals in Mississippi, by source, $1960-90$

15. Diagram showing total domestic withdrawals in Mississippi, by county, 1990

16. Diagram showing total commercial withdrawals in Mississippi, by county, 1990 .

17. Diagram showing total livestock withdrawals in Mississippi, by county, 1990

\section{TABLES}

Table 1. Total withdrawals in Mississippi, by county, 1990

2. Irrigation withdrawals and acreage in Mississippi, by county, 1990 .

3. Irrigation acreage, application rates, and withdrawals in Mississippi, by crop type, $1985-90$

4. Thermoelectric power withdrawals in Mississippi, by county, 1990

5. Aquaculture acreage, application rates, and withdrawals in Mississippi, 1970-90.

6. Aquaculture withdrawals in Mississippi, by county, 1990

7. People per household in Mississippi, 1960-90

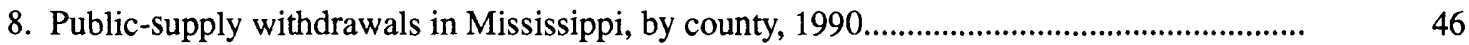

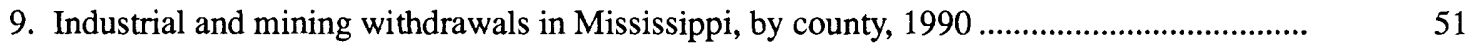

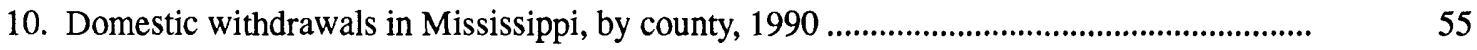

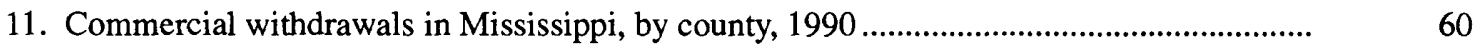

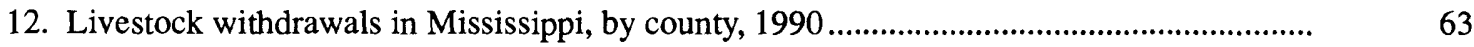


CONVERSION FACTORS AND ABBREVIATIONS

\begin{tabular}{rcl}
\hline Multiply & \multicolumn{1}{c}{ By } & To obtain \\
acre & 4,047 & square meter \\
foot $(\mathrm{ft})$ & 0.3048 & meter \\
foot per day $(\mathrm{ft} / \mathrm{d})$ & 0.3048 & meter per day \\
foot per year (ft/yr) & 0.3048 & meter per year \\
square foot $\left(\mathrm{ft}^{2}\right)$ & 0.09294 & square meter \\
mile (mi) & 1.609 & kilometer \\
gallon (gal) & 0.003785 & cubic meter \\
million gallons $(\mathrm{Mgal})$ & 3,785 & cubic meter \\
million gallons per day $(\mathrm{Mgal} / \mathrm{d})$ & 0.04381 & cubic meter per second \\
gigawatthour $(\mathrm{GWh})$ & 1,000 & megawatthour \\
\hline
\end{tabular}




\title{
Total Water Withdrawals in Mississippi, 1990
}

\author{
By Penny M. Johnson
}

\begin{abstract}
During 1990, the amount of water withdrawn from ground- and surface-water sources in Mississippi was about 3,600 Mgal/d (million gallons per day). Of this amount, 91 percent, or $3,300 \mathrm{Mgal} / \mathrm{d}$, was withdrawn from freshwater sources. Of the total freshwater withdrawals, about 82 percent, or $2,700 \mathrm{Mgal} / \mathrm{d}$, was withdrawn from ground-water sources.
\end{abstract}

Total water withdrawals in Mississippi in 1990 for eight categories of use were as follows: irrigation, 1,900 Mgal/d; thermoelectric power, $700 \mathrm{Mgal} / \mathrm{d}$; aquaculture, $400 \mathrm{Mgal} / \mathrm{d}$; public supply, $320 \mathrm{Mgal} / \mathrm{d}$; industrial and mining, $270 \mathrm{Mgal} / \mathrm{d}$; domestic, $33 \mathrm{Mgal} / \mathrm{d}$; commercial, 16 $\mathrm{Mgal} / \mathrm{d}$; and livestock, $16 \mathrm{Mgal} / \mathrm{d}$.

Overall, total withdrawals in Mississippi increased by 20 percent from 1985 to 1990 , although the total population decreased about 2 percent. During the same period, total freshwater withdrawals increased by about 17 percent. Total saline withdrawals increased by about 60 percent from 1985 due to an increase in saline withdrawals for thermoelectric power generation. Total fresh and saline surface-water withdrawals decreased by about 6 percent from 1985, due to a decrease in surface-water withdrawals for irrigation. Fresh ground-water withdrawals in Mississippi increased by about 33 percent, primarily due to an increase in irrigation.

Since 1960, total ground- and surface-water withdrawals increased 204 percent. Groundwater withdrawals increased 327 percent and surface-water withdrawals increased 70 percent for the same period. Irrigation had the greatest increase in withdrawals since 1960, with a 269 percent increase. Public supply had the second greatest, with a 178 percent increase.

\section{INTRODUCTION}

Although Mississippi has large quantities of ground and surface water that are available in nearly all parts of the State (Callahan and Barber, 1990b), increased demands for water have created a need for accurate, detailed information on current and historical water use. In recognition of this need, the U.S. Geological Survey (USGS), in cooperation with the Mississippi Department of Environmental Quality, Office of Land and Water Resources (OLWR; formerly the Mississippi State Board of Water Commissioners), began the Mississippi Water-Use Program in 1973. In 1978, the USGS initiated the National Water-Use Information Program to establish a nationwide water-use data base. Both the national program and the State program have similar goals: to collect, store, and disseminate consistent and accurate water-use information.

The Mississippi water-use program collects information on the following categories of water use: public supply, domestic, commercial, industrial, mining, thermoelectric power, livestock, irrigation, sewage treatment, and reservoir evaporation. This information is collected to meet the data needs of hydrologists and water managers at State and local agencies as well as the requirements of the national 
program. Detailed information on water use by cities, industries, and commercial establishments is stored in a site-specific data base.

\section{Purpose and Scope}

Every 5 years the site-specific data are added to the aggregate water-use data base for the National Water-Use Information Program. National estimates of water use have been compiled and published by the USGS every 5 years since 1955 (MacKichan, 1951, 1957; MacKichan and Kammerer, 1961; Murray, 1968; Murray and Reeves, 1972, 1977; and Solley and others, 1983, 1988, 1992). Estimates of the amount of water used in each county for fresh and saline ground and surface water for all water-use categories are stored in an aggregate water-use data base, along with the amount of wastewater discharged by sewage treatment plants. This report describes total withdrawals from surface- and ground-water sources in Mississippi in 1990. It is the fourth in a series of reports on water use in Mississippi; the previous reports were for 1975 (Callahan, 1976), 1980 (Callahan, 1983), and 1985 (Callahan and Barber, 1990a). These reports are designed to coincide with the national reports, with some exceptions. There are eight national categories of water use described in the report "Estimated Use of Water in the United States in 1990": public supply, domestic, commercial, industrial, mining, thermoelectric power, livestock, and irrigation (Solley and others, 1992). This report for Mississippi discusses eight categories listed in order, beginning with the category with the largest total withdrawals: irrigation; thermoelectric power; aquaculture; public supply; industrial and mining; domestic; commercial; and livestock. The mining category is included in the industrial category, and the livestock category is separated into the categories of aquaculture and livestock.

\section{Data-Collection Techniques}

Continuing efforts are made to improve data collection techniques within the national and State water-use programs. As techniques improve, more reliable water-use data are obtained. As part of the data-collection process for 1990, in May 1991, the OLWR distributed a two-page water-use questionnaire to the 50 largest public suppliers in the State and a one-page water-use questionnaire to the 50 largest "other users" in the State. The "other users" questionnaire was sent to thermoelectric power plants, industries, and some commercial establishments. These 100 users were selected based on total permitted withdrawals for each facility. The questionnaires requested the 1990 monthly withdrawals for all permitted water wells or surface intakes. Other data-collection techniques and sources of data for each water-use category are described in detail with each category.

\section{TOTAL WITHDRAWALS, BY CATEGORY}

During 1990, total withdrawals from ground- and surface-water sources in Mississippi were about $3,600 \mathrm{Mgal} / \mathrm{d}$ (fig. 1). The largest withdrawals were concentrated in the Mississippi River alluvial plain of northwestern Mississippi (commonly referred to as the "Delta"; fig. 2). Bolivar County had the largest withdrawals, with about $460 \mathrm{Mgal} / \mathrm{d}$, followed by Washington County, with about $380 \mathrm{Mgal} / \mathrm{d}$ (table 1). Total withdrawals increased about $600 \mathrm{Mgal} / \mathrm{d}$ (about 20 percent) from 1985 to 1990 (fig. 3), although the total population of Mississippi decreased about 2 percent (U.S. Bureau of the Census, 1991). Total freshwater withdrawals, about $3,300 \mathrm{Mgal} / \mathrm{d}$, increased 17 percent from 1985 , with about 80 percent, or $2,700 \mathrm{Mgal} / \mathrm{d}$, withdrawn from ground-water sources. Total freshwater withdrawals from ground-water sources increased 33 percent from 1985 to 1990, primarily due to an increase in irrigation. Total freshwater 
withdrawals from surface-water sources decreased about 22 percent, to about $650 \mathrm{Mgal} / \mathrm{d}$ during the 5-year period, with the largest withdrawals occurring in the counties with large thermoelectric power withdrawals (fig. 2; table 4). Total saline withdrawals were about $320 \mathrm{Mgal} / \mathrm{d}$, an increase of 60 percent from 1985, due to an increase in saline withdrawals for thermoelectric power generation. Total fresh and saline surface-water withdrawals decreased by 6 percent from 1985, due to a decrease in irrigation surface-water withdrawals (fig. 3).

Since 1960 , total withdrawals increased 204 percent. Total ground-water withdrawals have increased 327 percent, and total surface-water withdrawals have increased 70 percent (fig. 3). Withdrawals for irrigation increased 269 percent for the same period, followed by withdrawals for public supply, 178 percent (fig. 4).

\section{Irrigation}

Irrigation water use, the largest category of withdrawals in Mississippi, includes all water artificially applied to farm and horticultural crops, such as rice, cotton, and soybeans. Water-use data for irrigation are obtained from several sources. Information on the number of acres irrigated, types of irrigation system used, and application rates was obtained from the Mississippi Agricultural Statistics Service (Hugh McWilliams, oral and written commun., 1991), the Mississippi Cooperative Extension Service (Jim Thomas, oral and written commun., 1991), and the Yazoo Mississippi Delta Joint Water Management District (Dean Pennington, oral commun., 1991). A coefficient of 10 percent was added, by county, to the total ground- and surface-water irrigation withdrawals to compensate for conveyance losses.

Irrigation withdrawals were estimated to be about $1,900 \mathrm{Mgal} / \mathrm{d}$ for 1990 (table 2). Of the total irrigated acreage, 38 percent was irrigated by spray methods (including center pivot, traveling gun, trickle, and drip systems) and 62 percent was irrigated by flooding, furrow, and ditch methods. About 95 percent of these withdrawals was in the Delta (fig. 5). Irrigation withdrawals accounted for about 52 percent of all water withdrawn in Mississippi and 66 percent of all ground-water withdrawals in the State (fig. 1).

Withdrawals for irrigating rice accounted for about 50 percent of the total withdrawals for irrigation. About $950 \mathrm{Mgal} / \mathrm{d}$ of water was used to irrigate 260,000 acres of rice during 1990 . Withdrawals for rice irrigation increased 19 percent since 1985 (table 3). Soybean irrigation used about $570 \mathrm{Mgal} / \mathrm{d}$ on about 500,000 acres, and cotton irrigation used about $350 \mathrm{Mgal} / \mathrm{d}$ on about 390,000 acres (table 3).

Total withdrawals for irrigation have steadily increased since 1965 (fig. 6). Since 1960, total withdrawals for irrigation have increased 269 percent. Total withdrawals for irrigation increased 34 percent from 1985 to 1990, whereas total irrigated acreage increased 52 percent (fig. 6). Irrigated acreage has been increasing at a faster rate than withdrawals. Factors that might be causing this are lower application rates for rice and the increase in other irrigated crops that do not use as much water per acre as rice (table 3 ).

\section{Thermoelectric Power}

The thermoelectric power category, the second largest category of withdrawals in Mississippi, includes water used in the generation of electric power with fossil fuel or nuclear energy. Cooling water accounts for most of the water used in this category, with lesser amounts of water used for boiler water, 
Table 3. Irrigation acreage, application rates, and withdrawals in Mississippi, by crop type, 1985-90 [Figures may not add to totals because of independent rounding]

\begin{tabular}{|c|c|c|c|c|c|c|}
\hline \multirow[b]{2}{*}{ Crop type } & \multicolumn{3}{|c|}{1985} & \multicolumn{3}{|c|}{1990} \\
\hline & Acreage & $\begin{array}{l}\text { Application } \\
\text { rate, } \\
\text { in feet per } \\
\text { acre }\end{array}$ & $\begin{array}{l}\text { Withdrawais, } \\
\text { in Mgal/d }\end{array}$ & Acreage & $\begin{array}{c}\text { Application } \\
\text { rate, } \\
\text { in feet per acre }\end{array}$ & $\begin{array}{l}\text { Withdrawals, } \\
\text { In Mgal/d }\end{array}$ \\
\hline Rice & 192,180 & 4.64 & 795.50 & 259,505 & 4.10 & 949.17 \\
\hline Soybeans & 367,614 & 1.30 & 426.33 & 495,156 & 1.30 & 574.25 \\
\hline Cotton & 193,623 & 1.00 & $1,72.73$ & 388,494 & 1.00 & 346.57 \\
\hline $\begin{array}{l}\text { Corn, sorghum, and } \\
\text { other vegetables }\end{array}$ & $18,741.50$ & 0.50 & 8.36 & 31,986 & 0.50 & 14.27 \\
\hline Fruits and nuts & 1,072 & 0.083 & 0.08 & 4,869 & 0.083 & 0.36 \\
\hline Total & 773,231 & & $1,403.00^{\mathrm{a}}$ & $1,180,010$ & & $1,884.62$ \\
\hline
\end{tabular}

a. Revised from Callahan and Barber, $1990^{\mathrm{a}}$

sanitary purposes, and fire protection. Information on fresh and saline withdrawals was obtained from the OLWR “other users" questionnaire. All 15 power-generation plants operating in Mississippi were included in the questionnaire. Fourteen of these plants are fossil-fueled, and one is nuclear-powered.

During 1990, about $700 \mathrm{Mgal} / \mathrm{d}$ of fresh and saline water was withdrawn for thermoelectric power generation, or about 20 percent of the total withdrawals in Mississippi (fig. 1; table 4). Of this amount, saline water accounted for about 46 percent or $320 \mathrm{Mgal} / \mathrm{d}$ of the total thermoelectric power withdrawals in the State. Surface water accounted for 94 percent of all thermoelectric power withdrawals, or about $660 \mathrm{Mgal} / \mathrm{d}$. Harrison County had the largest surface-water withdrawals for thermoelectric power generation in the State, and Warren County had the second largest (fig. 7; table 4). Thermoelectric power generation accounted for 68 percent of total surface-water withdrawals in the State (fig. 1).

Water withdrawn for thermoelectric power generation during 1990 increased 5 percent since 1985. Since 1960, withdrawals increased 154 percent (fig. 8). A significant decrease in withdrawals occurred between 1980 and 1985 primarily because the two largest fossil-fueled plants withdrew less fresh surface water and generated less power in 1985 than in 1980. However, power generation steadily increased since 1960 because the nuclear power plant in Claiborne County began operation in 1985 (fig. 8). Surface-water withdrawals for thermoelectric power generation decreased because the nuclear power plant withdrew ground water instead of surface water for cooling purposes.

\section{Aquaculture}

Aquaculture water use, the third largest category of withdrawals in Mississippi, is defined as water use associated with the production of fish in captivity (catfish farming), excluding fish hatcheries. In Mississippi, catfish are grown predominantly in man-made ponds that lose water through exfiltration, 
overflow, evaporation, and periodic drainage. About 96 percent of all catfish farming in Mississippi takes place in the Delta, where all the water is supplied from ground-water sources because of its availability, quality, and uniform temperature. In other areas of the State, ground-water withdrawals are about 85 percent of the total withdrawals for catfish farming (Dean Pennington, oral commun., 1991).

Total freshwater withdrawals were estimated by multiplying an application rate by the total pond acreage in a county. Information on pond acreage was obtained from the Mississippi Cooperative Extension Service (M.W. Brunson, oral and written commun., 1991). The average application rate for 1990 was 4.67 feet per acre per year (Dean Pennington, oral commun., 1991) (table 5).

During 1990, about 95,000 pond acres were used for catfish production (table 5). Total withdrawals for aquaculture were estimated to be about $400 \mathrm{Mgal} / \mathrm{d}$ for 1990 , or about 11 percent of the total withdrawals for 1990 (fig. 1; table 6). Humphreys County had the largest withdrawals with 120 Mgal/d, with Sunflower County the second largest with $95 \mathrm{Mgal} / \mathrm{d}$ (fig. 9). Since 1985, catfish-pond acreage in Mississippi increased 29 percent, whereas total withdrawals for aquaculture increased about 8 percent (table 5). Withdrawals have steadily increased since 1975 (fig. 10). Since 1970, acreage has increased 249 percent, whereas withdrawals increased only 116 percent, due to a decrease in the application rate (table 5).

Table 5. Aquaculture acreage, application rates, and withdrawals in Mississippi, 1970-90

\begin{tabular}{cccc}
\hline Year & Acreage & $\begin{array}{c}\text { Appllcation } \\
\text { rate, } \\
\text { in feet per acre }\end{array}$ & $\begin{array}{c}\text { Total withdrawals, } \\
\text { in Mgal/d }\end{array}$ \\
\hline 1970 & 27,201 & 7.50 & 182.82 \\
1975 & 23,158 & 7.50 & 155.63 \\
1980 & 39,000 & 7.50 & 283.90 \\
1985 & 73,600 & 5.05 & $365.58^{\mathrm{a}}$ \\
1990 & 94,900 & 4.67 & 395.18 \\
\hline
\end{tabular}

a. Revised from Callahan and Barber, $1990^{\mathrm{a}}$

\section{Public Supply}

Public supply refers to water withdrawn by public and private water suppliers and delivered to multiple users for domestic, commercial, industrial, and thermoelectric power uses. Public supply includes public and private water systems that furnish water to at least 25 people, or that have a minimum of 15 service connections.

Data on public-supply withdrawals were obtained from several sources. Of the 50 public suppliers receiving the OLWR questionnaire, 21 responded with 1990 withdrawal data. Records of the Mississippi State Department of Health, Division of Water Supply (Bill Wall, oral and written commun., 
1991), and 1985 facility and withdrawal information from the USGS site-specific data base were used to complete the estimate of 1990 withdrawals.

Withdrawals were estimated by one of several methods, depending on the information available. Most public suppliers have records of how much water they sell, or how many connections they serve. They may have an estimate of the total population they serve. In cases where the amount of water sold is known, the amount of water withdrawn is estimated by applying a loss factor (assumed to be 30 percent unless other information is available) to the amount sold. The loss factor accounts for water lost during treatment and for leaks in the distribution system. If only the number of connections was known, the number of customers was estimated, after subtracting industrial and commercial connections, by using an estimate of the number of people per household for each county (U.S. Bureau of the Census, 1991). The average number of people per household for Mississippi was 2.55 during 1990 (table 7). This number decreased since 1960 when the average was 4.00 people per household (table 7 ). If only the number of customers was known, the withdrawal was estimated by multiplying the number of customers by an estimated use of 60 gallons per day per person.

Table 7. People per household in Mississippi, 1960-90

\begin{tabular}{cc}
\hline Year & People per household \\
\hline 1960 & 4.00 \\
1965 & 4.00 \\
1970 & 3.50 \\
1975 & 3.50 \\
1980 & 3.50 \\
1985 & 3.20 \\
1990 & 2.55 \\
\hline
\end{tabular}

Public-supply withdrawals were estimated to be about $320 \mathrm{Mgal} / \mathrm{d}$ for 1990 , or about 9 percent of the total withdrawals in Mississippi (fig. 1; table 8). Ground water was the source for about 88 percent of these withdrawals for a total of $280 \mathrm{Mgal} / \mathrm{d}$. Three public suppliers withdrew surface water for public-supply use in 1990: Jackson, Meridian, and Columbus, for a total of about $38 \mathrm{Mgal} / \mathrm{d}$ or about 12 percent of the total public-supply withdrawals (fig. 11). Hinds County had the largest withdrawals with 39 $\mathrm{Mgal} / \mathrm{d}$, with DeSoto County the second largest with $21 \mathrm{Mgal} / \mathrm{d}$ (fig. 11). During 1990, 911 public suppliers, including 173 new public suppliers since 1985, withdrew ground or surface water. The total public-supplied withdrawals in 1990 increased 3 percent from 1985 (fig. 12). Since 1960, public-supplied withdrawals increased 178 percent (fig. 12).

\section{Industrial and Mining}

Industrial and mining water use includes water for such purposes as processing, washing, and cooling in facilities that manufacture products, and water for the extraction of naturally occurring materials, dewatering, milling, and other preparations that are part of mining activities. Major water-using industries and mining operations in Mississippi are producers of chemical and allied 
products, paper and allied products, petroleum refining, agriculture chemicals and fertilizers, and sand, clay and gravel mining. Industries that withdraw their own water for manufacturing processes often obtain sanitary and drinking water from a public supplier.

Information on industries was obtained from the OLWR "other users" questionnaire and from the Mississippi water-use data base. Twenty industries responded to the questionnaire with withdrawal data. Mining withdrawal amounts were estimated from 1985 data and from 1990 estimated State totals for each commodity (Doss White, U.S. Bureau of Mines, oral and written commun., 1991).

Industrial and mining users withdrew an estimated $270 \mathrm{Mgal} / \mathrm{d}$, or about 8 percent of the total withdrawals during 1990 (fig. 1; table 9). Of this amount, about 54 percent was from ground-water sources, and 46 percent was from surface-water sources. The largest withdrawals were in Jackson County with 59 $\mathrm{Mgal} / \mathrm{d}$ and Adams County with $43 \mathrm{Mgal} / \mathrm{d}$ (fig. 13). Industrial and mining withdrawals increased 15 percent since 1985, with surface-water withdrawals increasing by 23 percent (fig. 14). Since 1960 , industrial and mining withdrawals increased 60 percent (fig.14). Industrial and mining is the third-largest category of surface-water withdrawals (13 percent) in Mississippi (fig. 1).

\section{Domestic}

Domestic water use includes water for normal household purposes, such as drinking, food preparation, bathing, washing clothes and dishes, flushing toilets, and watering lawns and gardens. Most water for domestic use is supplied by public suppliers. Self-supplied water for domestic use usually is withdrawn from wells.

Self-supplied domestic users (usually rural homeowners) rarely meter their withdrawals, and withdrawals were estimated based on the self-supplied population. The self-supplied population for 1990 was estimated by subtracting the estimated population served by public suppliers within the county from the total population of that county. Domestic withdrawals were then calculated by multiplying the total self-supplied population of a county by 50 gallons per day per person.

Domestic withdrawals were estimated to be about $33 \mathrm{Mgal} / \mathrm{d}$ for 1990 , with the largest withdrawals in Harrison County with $3.3 \mathrm{Mgal} / \mathrm{d}$ and Hinds County with $2.0 \mathrm{Mgal} / \mathrm{d}$ (fig. 15; table 10). Domestic withdrawals increased about 106 percent since 1985. The estimated self-supplied population increased from 14 percent of the total population in 1985 to 26 percent in 1990 . However, the increase in self-supplied population and domestic withdrawals is due to the different methods used to calculate these figures in 1990. Because domestic and commercial withdrawals are each less than 1 percent of the total withdrawals for the State, they are combined in figure 1. Since 1960, domestic withdrawals decreased 9 percent.

\section{Commercial}

Commercial water use includes water for motels, hotels, restaurants, office buildings, other commercial facilities, and civilian and military institutions. Most commercial users receive their water from a public supplier. Commercial withdrawal data were obtained from the OLWR "other users" questionnaire and from 1985 data. Withdrawal data from five commercial users that responded to the questionnaire were supplemented with 1985 withdrawal data. 
Total commercial withdrawals for Mississippi during 1990 were estimated to be about 16 $\mathrm{Mgal} / \mathrm{d}$. The largest withdrawals were $2.1 \mathrm{Mgal} / \mathrm{d}$ in Forrest County and $2.0 \mathrm{Mgal} / \mathrm{d}$ in Oktibbeha County (fig. 16; table 11). Ground water was the only source of water used for commercial use.

\section{Livestock}

Livestock water use includes water for livestock, feed lots, dairies, production of poultry and eggs, and other on-farm needs. Water-use estimates for livestock were made by multiplying the number of each type of animal in a county by an estimate of use per animal. Livestock populations were obtained from the Mississippi Department of Agriculture and Commerce (Hugh McWilliams, oral and written commun., 1991), and poultry populations were obtained from Mississippi State University, Poultry Science Department (R.L. Haynes, oral and written commun., 1991). Coefficients for water use per animal were obtained from two sources. Livestock water use per animal was estimated by using the same coefficients used for 1985: dairy cattle, $20 \mathrm{gal} / \mathrm{d}$; other cattle, $10 \mathrm{gal} / \mathrm{d}$; and hogs, $3 \mathrm{gal} / \mathrm{d}$. Poultry water use per animal was estimated to be $0.004 \mathrm{gal} / \mathrm{d}$ (R.L. Haynes, oral commun., 1991).

Total withdrawals for livestock use were estimated to be about $16 \mathrm{Mgal} / \mathrm{d}$ for 1990 . The largest withdrawals were $0.68 \mathrm{Mgal} / \mathrm{d}$ in Scott County and $0.51 \mathrm{Mgal} / \mathrm{d}$ in Jones County (fig. 17; table 12). Ground water was the estimated source for about 40 percent of the livestock withdrawals. Total withdrawals for livestock use decreased 4 percent from 1985 to 1990 . Since 1960, livestock withdrawals decreased 40 percent, due to a gradual decline in the numbers of cattle and hogs for the same period.

\section{SUMMARY}

Total withdrawals in Mississippi during 1990 were estimated to be 3,600 Mgal/d, an increase of 20 percent from 1985, although the total population in the State decreased by about 2 percent during the same period. Freshwater withdrawals were estimated to be $3,300 \mathrm{Mgal} / \mathrm{d}$, an increase of 17 percent from 1985. Ground-water withdrawals accounted for about 74 percent of the total withdrawals in the State, or about $2,700 \mathrm{Mgal} / \mathrm{d}$. This amount is about 33 percent greater than the 1985 total ground-water withdrawals, primarily due to an increase in irrigation. Surface-water withdrawals were estimated to be about $960 \mathrm{Mgal} / \mathrm{d}$, or about 6 percent less than during 1985 due to a decrease in irrigation surface-water withdrawals. Saline surface-water withdrawals increased about 60 percent from 1985 , primarily due to an increase in saline thermoelectric power withdrawals.

Total withdrawals increased 204 percent since 1960, with ground-water withdrawals increasing 327 percent, and surface-water withdrawals increasing 70 percent over the same period. Since 1960 , irrigation withdrawals had the most significant increase, 269 percent, followed by a 178 percent increase in public-supply withdrawals.

Total withdrawals in Mississippi in 1990 for eight categories of use were as follows: irrigation, $1,900 \mathrm{Mgal} / \mathrm{d}$; thermoelectric power, $700 \mathrm{Mgal} / \mathrm{d}$; aquaculture, $400 \mathrm{Mgal} / \mathrm{d}$; public supply, $320 \mathrm{Mgal} / \mathrm{d}$; industrial and mining, $270 \mathrm{Mgal} / \mathrm{d}$; domestic, $33 \mathrm{Mgal} / \mathrm{d}$; commercial, $16 \mathrm{Mgal} / \mathrm{d}$; and livestock, $16 \mathrm{Mgal} / \mathrm{d}$. 


\section{SELECTED REFERENCES}

Callahan, J.A., 1976, Water use in Mississippi, 1975: U.S. Geological Survey Water-Resources Investigations Report $76-125,1$ sheet.

1983, Water use in Mississippi, 1980: U.S. Geological Survey Open-File Report 83-224, 1 sheet.

Callahan, J.A., and Barber, N.L., 1989, Water-use data collection program in Mississippi, in Proceedings of the 19th Mississippi Water Resources Conference, March 1989, Jackson, Mississippi: Water Resources Research Institute, Mississippi State, Miss., p. 53-57.

1990a, Freshwater use in Mississippi, 1985: U.S. Geological Survey Water-Resources Investigations Report $88-4229,1$ sheet.

1990b, Mississippi water supply and use, in U.S. Geological Survey, National Water Summary, 1988-89--Water supply and use: U.S. Geological Survey Water-Supply Paper 2350, p. 321-328.

MacKichan, K.A., 1951, Estimated water use in the United States, 1950: U.S. Geological Survey Circular 115, 13 p. 1957, Estimated water use in the United States, 1955: U.S. Geological Survey Circular 398, 18 p.

MacKichan, K.A., and Kammerer, J.C., 1961, Estimated use of water in the United States, 1960: U.S. Geological Survey Circular 456, 26 p.

Murray, C.R., 1968, Estimated use of water in the United States, 1965: U.S. Geological Survey Circular 556, 53 p.

Murray, C.R., and Reeves, E.B., 1972, Estimated use of water in the United States, 1970: U.S. Geological Survey Circular 676, $37 \mathrm{p}$.

1977, Estimated use of water in the United States, 1975: U.S. Geological Survey Circular 765, 37 p.

Johnson, P.M., 1993, Freshwater withdrawals in Mississippi, 1990, in Proceedings of the 23rd Mississippi Water Resources Conference, April 1993, Jackson, Mississippi: Water Resources Research Institute, Mississippi State, Miss., p. 125-130.

Solley, W.B., Chase, E.B., and Mann, W.B., IV, 1983, Estimated use of water in the United States in 1990: U.S. Geological Survey Circular 1001, 56 p.

Solley, W.B., Merk, C.F., and Pierce, R.R., 1988, Estimated use of water in the United States in 1985: U.S. Geological Survey Circular 1004, 82 p.

Solley, W.B., Pierce, R.R., and Perlman, H.A., 1992, Estimated use of water in the United States in 1990: U.S. Geological Survey Circular 1081, 76 p.

U.S. Bureau of the Census, 1991, Census of population and housing, 1990: Public Law 94-171 Data for Mississippi [machine-readable data files], prepared by the Bureau of the Census-Washington, D.C. 


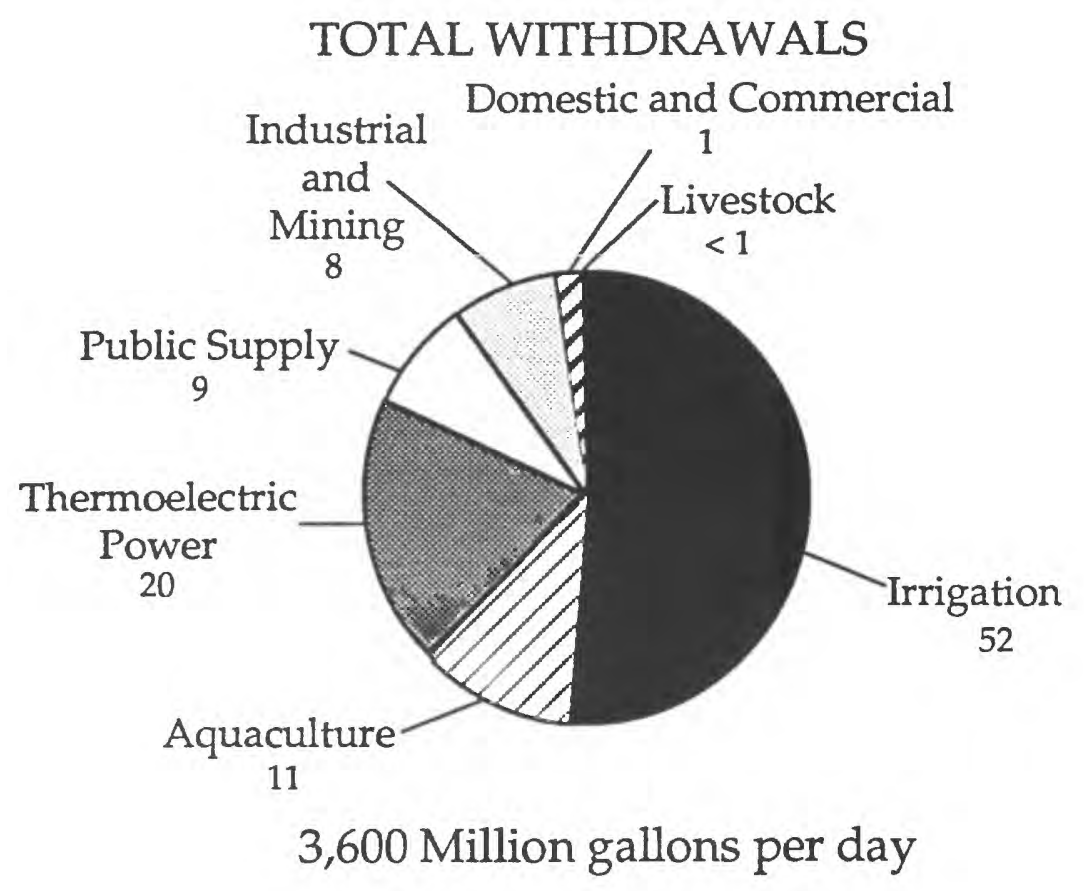

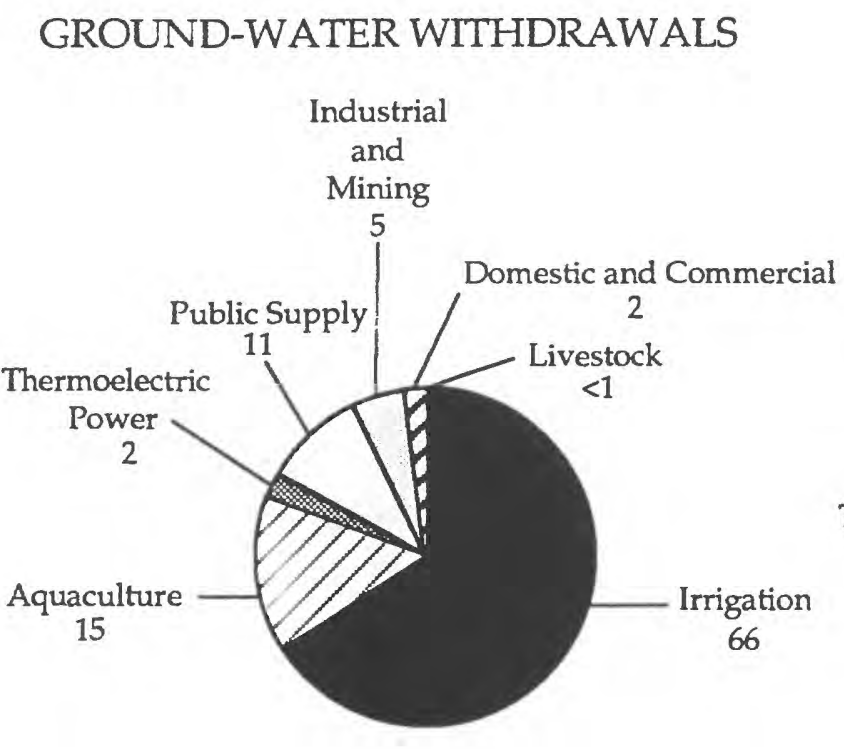

2,700 Million gallons per day
SURFACE-WATER WITHDRAWALS

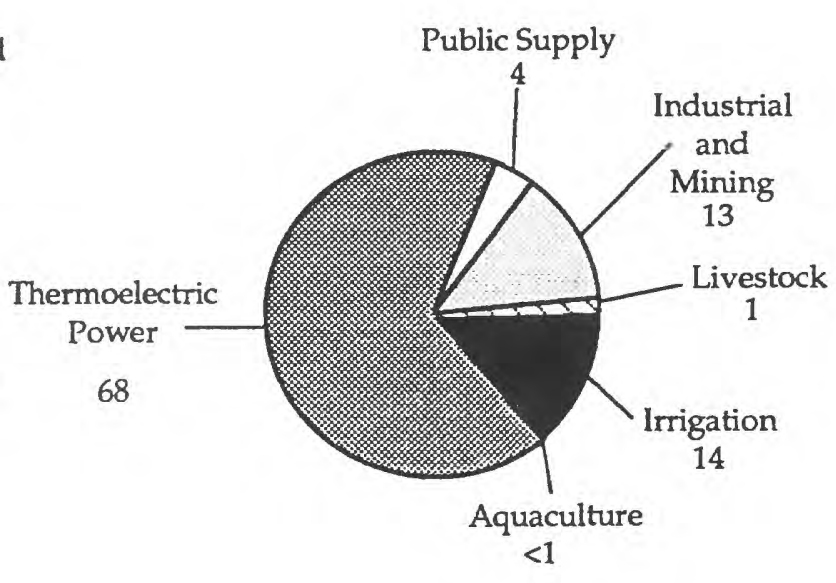

960 Million gallons per day

Figure 1.--Total withdrawals in Mississippi, by category of use, 1990. (Numbers are in percent and may total to more than 100 due to rounding.) 
TOTAL WITHDRAWALS

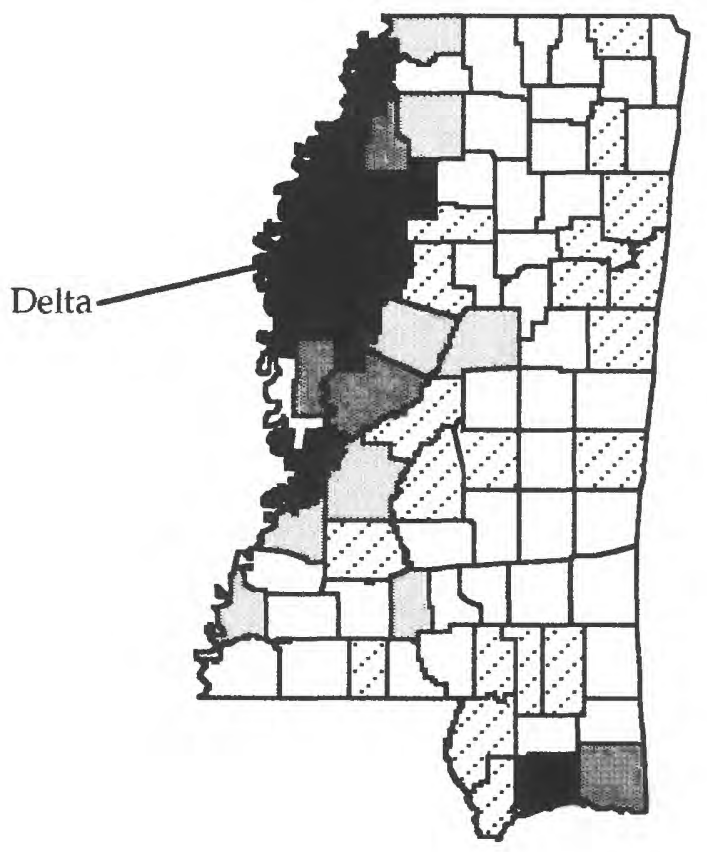

EXPLANATION

Withdrawals, in million

gallons per day

$\begin{array}{cc}\square \quad & 0-5 \\ \square \quad 5-25 \\ \square \quad 25-50 \\ \quad 50-100 \\ 100-500\end{array}$
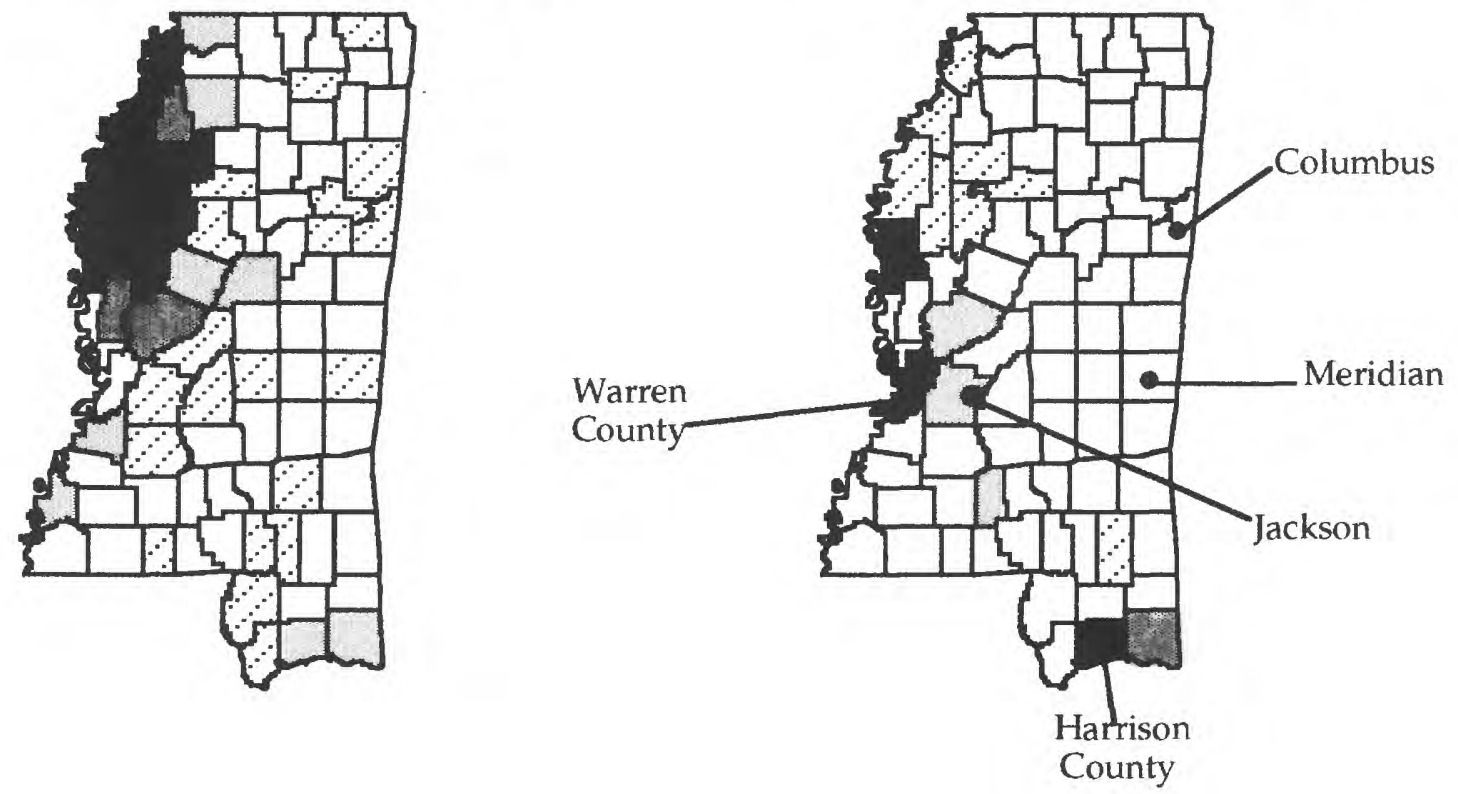

Figure 2.--Total withdrawals for all offstream water-use categories in Mississippi, by county and source, 1990. 


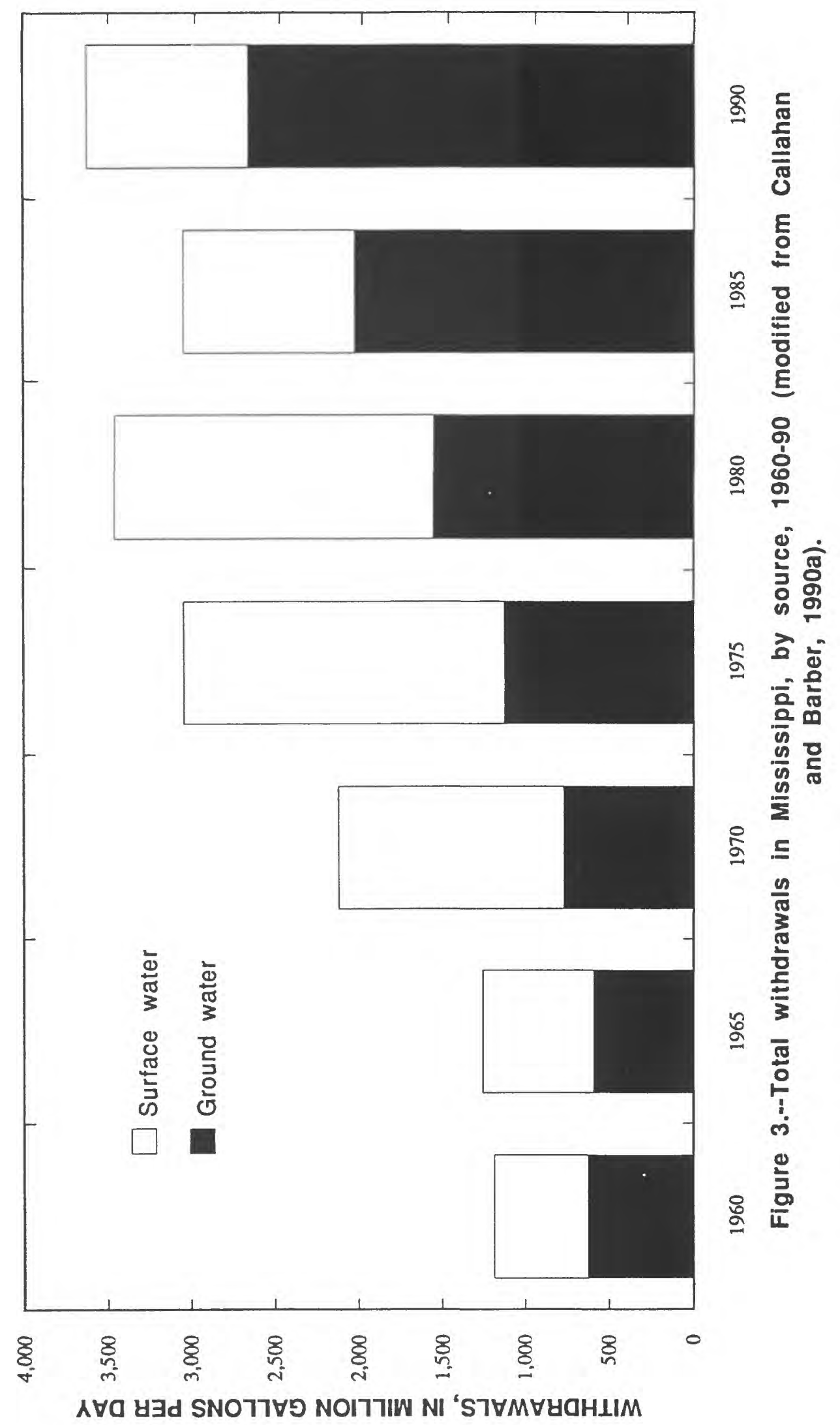




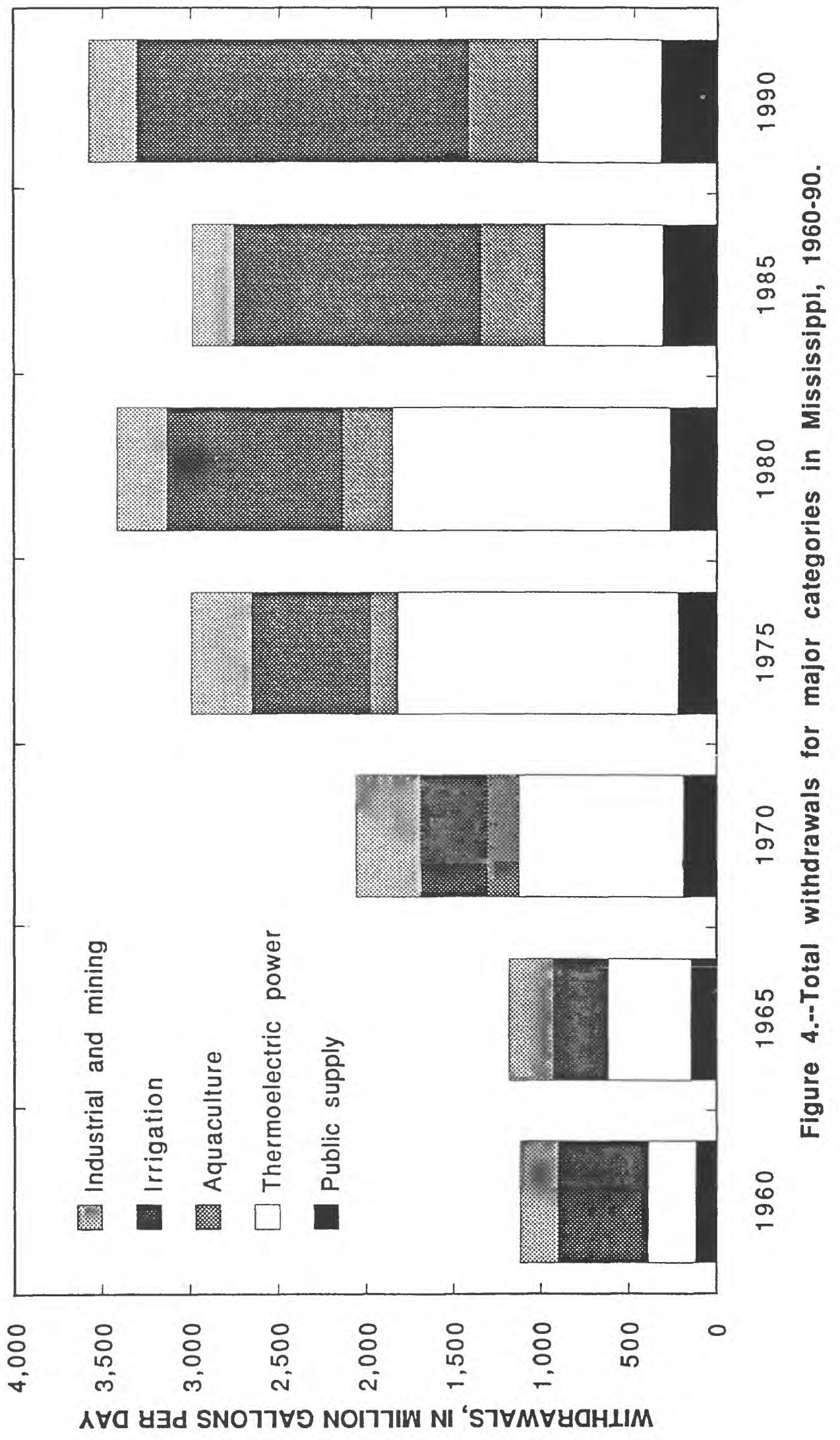




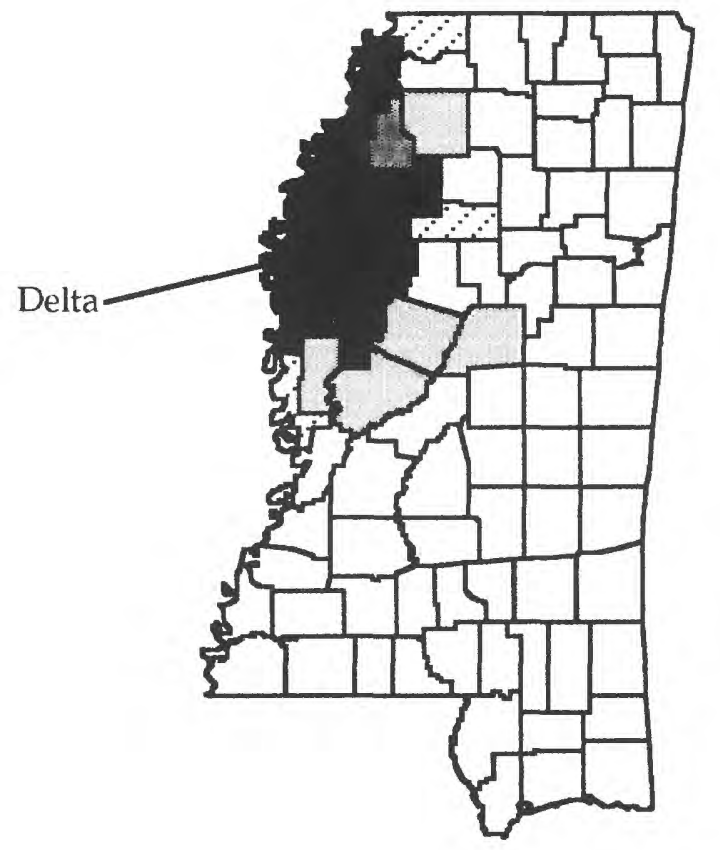

\section{EXPLANATION}

Withdrawals, in million gallons per day

$\square \quad 0-5$

Q $5-25$

प $25-50$

(100 $50-100$

$100-500$

Figure 5.--Total irrigation withdrawals in Mississippi, by county, 1990 . 


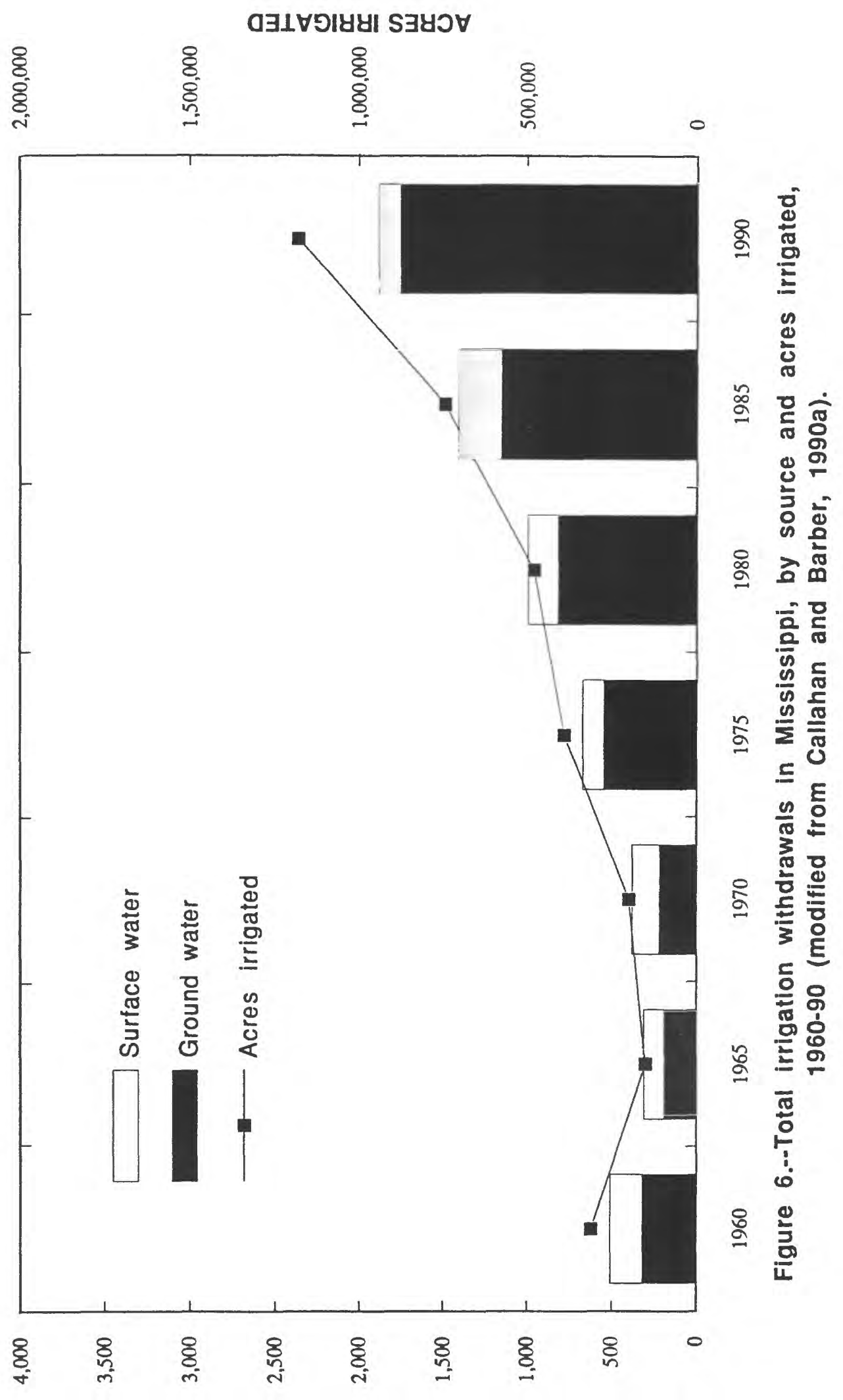

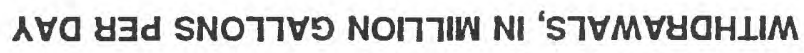




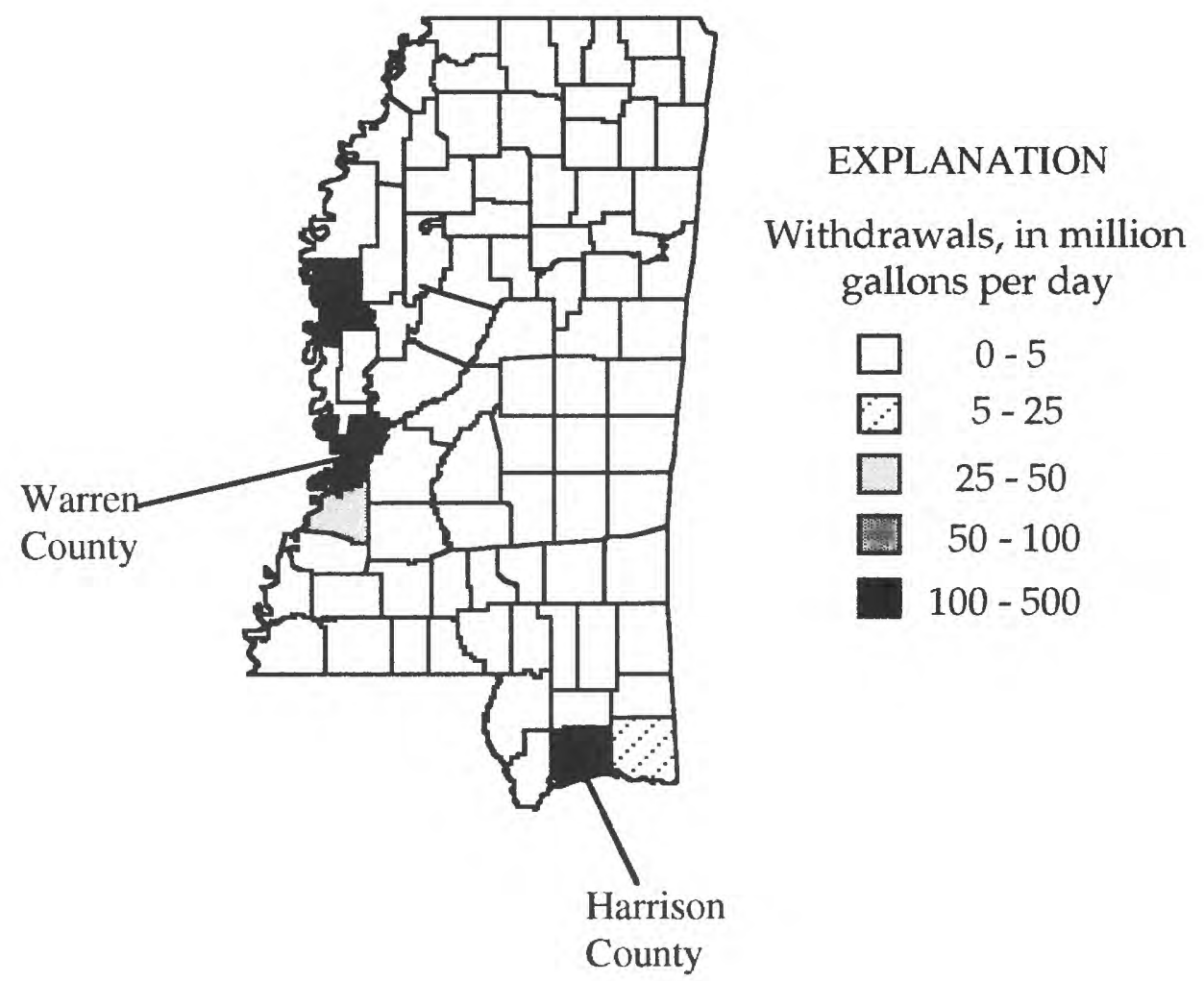

Figure 7.--Total thermoelectric power withdrawals in Mississippi, by county, 1990. 


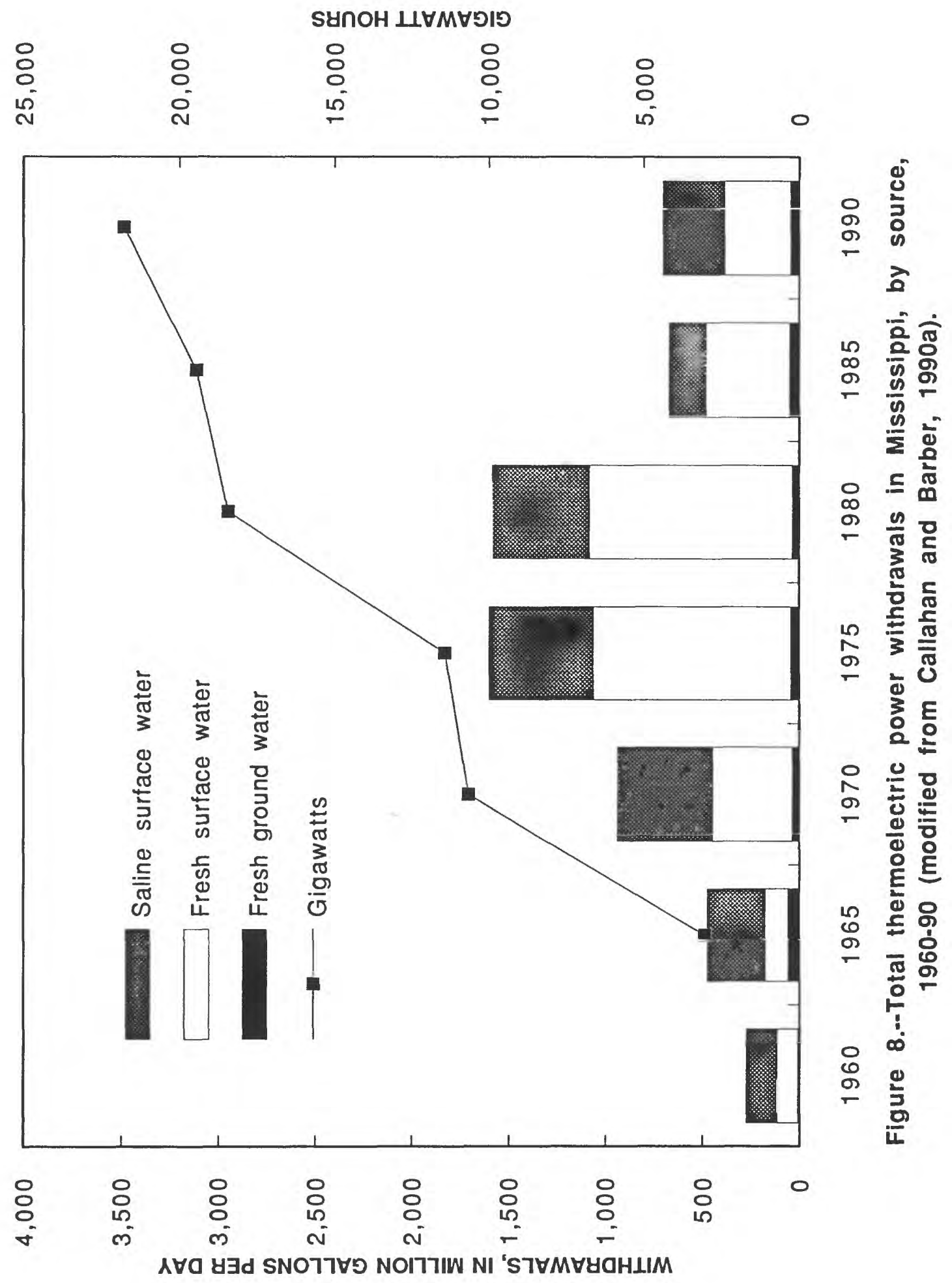




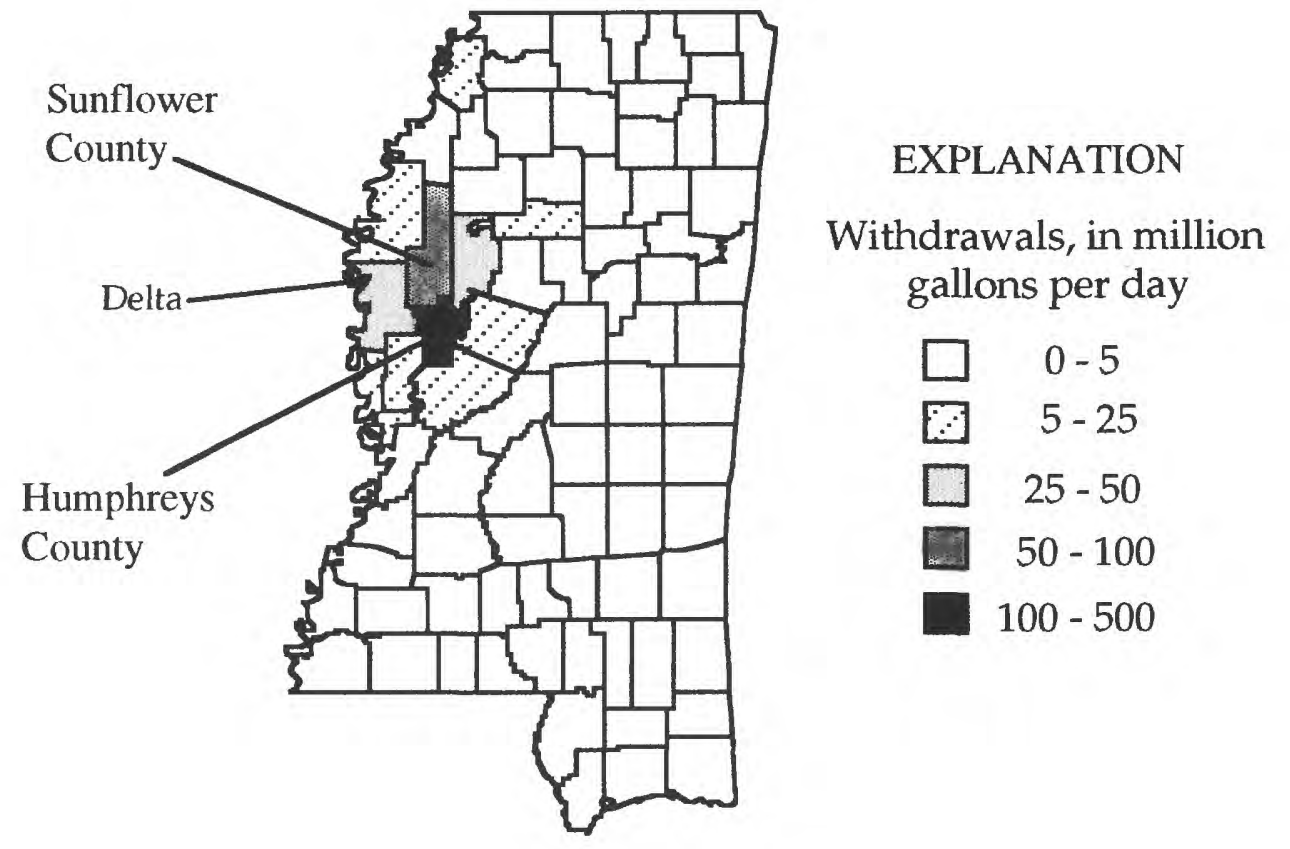

Figure 9.--Total aquaculture withdrawals in Mississippi, by county, 1990. 


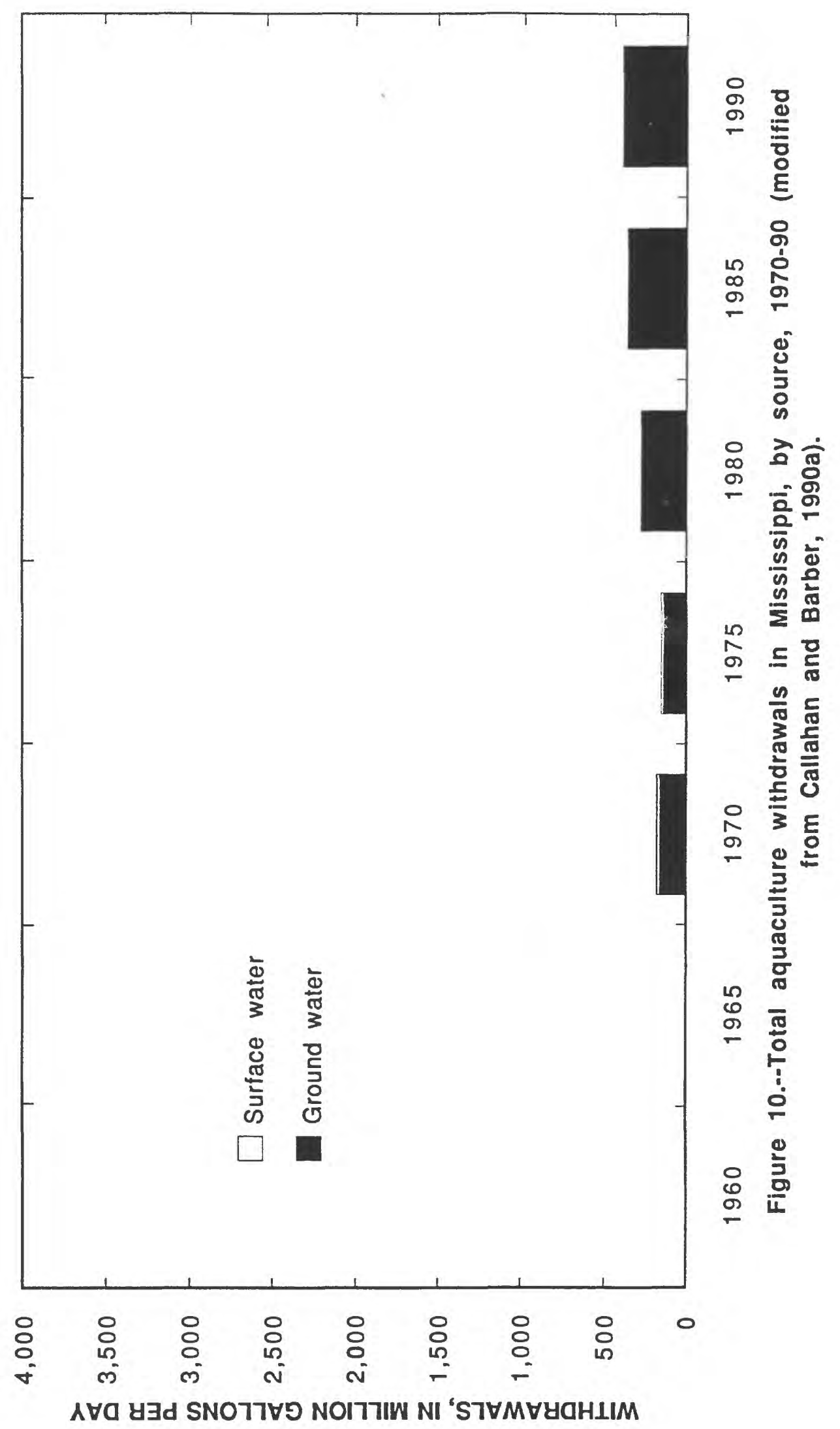




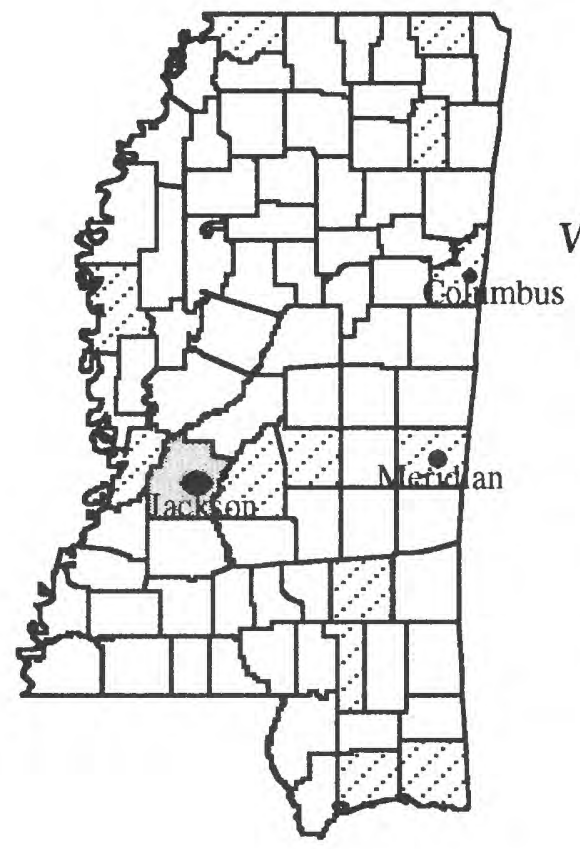

\section{EXPLANATION}

Withdrawals, in million gallons per day

$\square \quad 0-5$

[ $5-25$

$\square \quad 25-50$

50-100

100-500

Figure 11.--Total public-supply withdrawal in Mississippi, by county, 1990. 


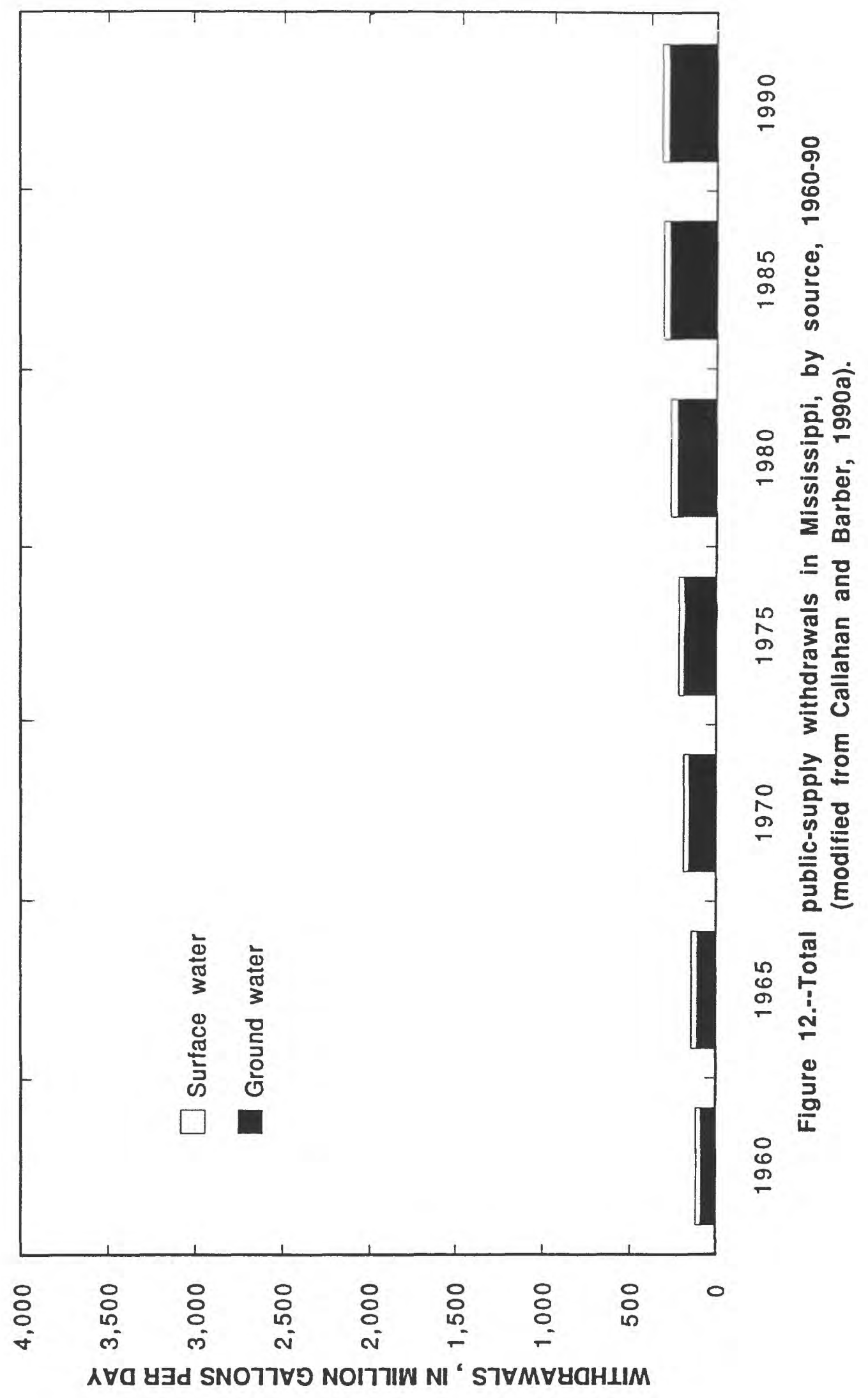




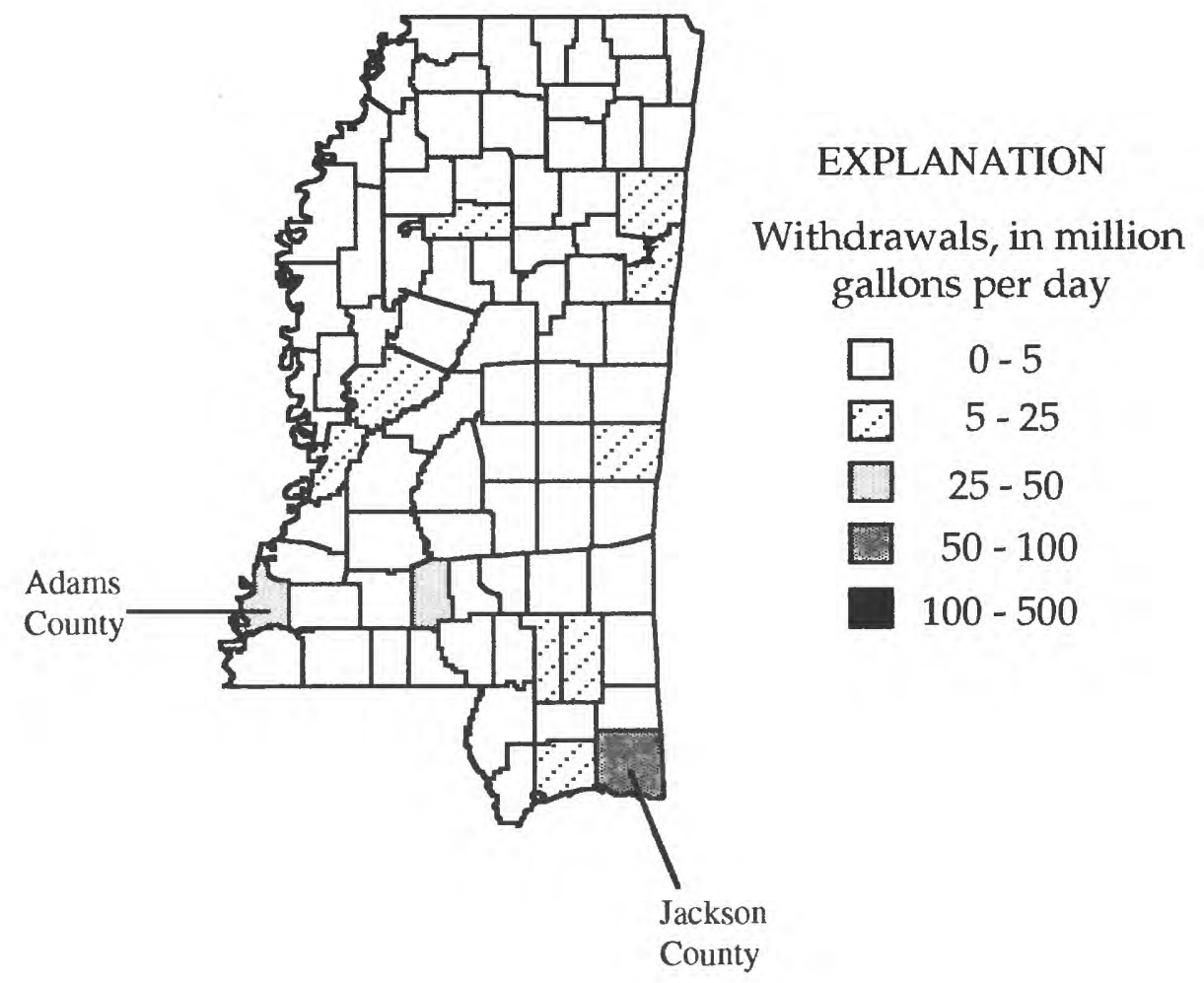

Figure 13.--Total industrial and mining withdrawals in Mississippi, by county, 1990. 


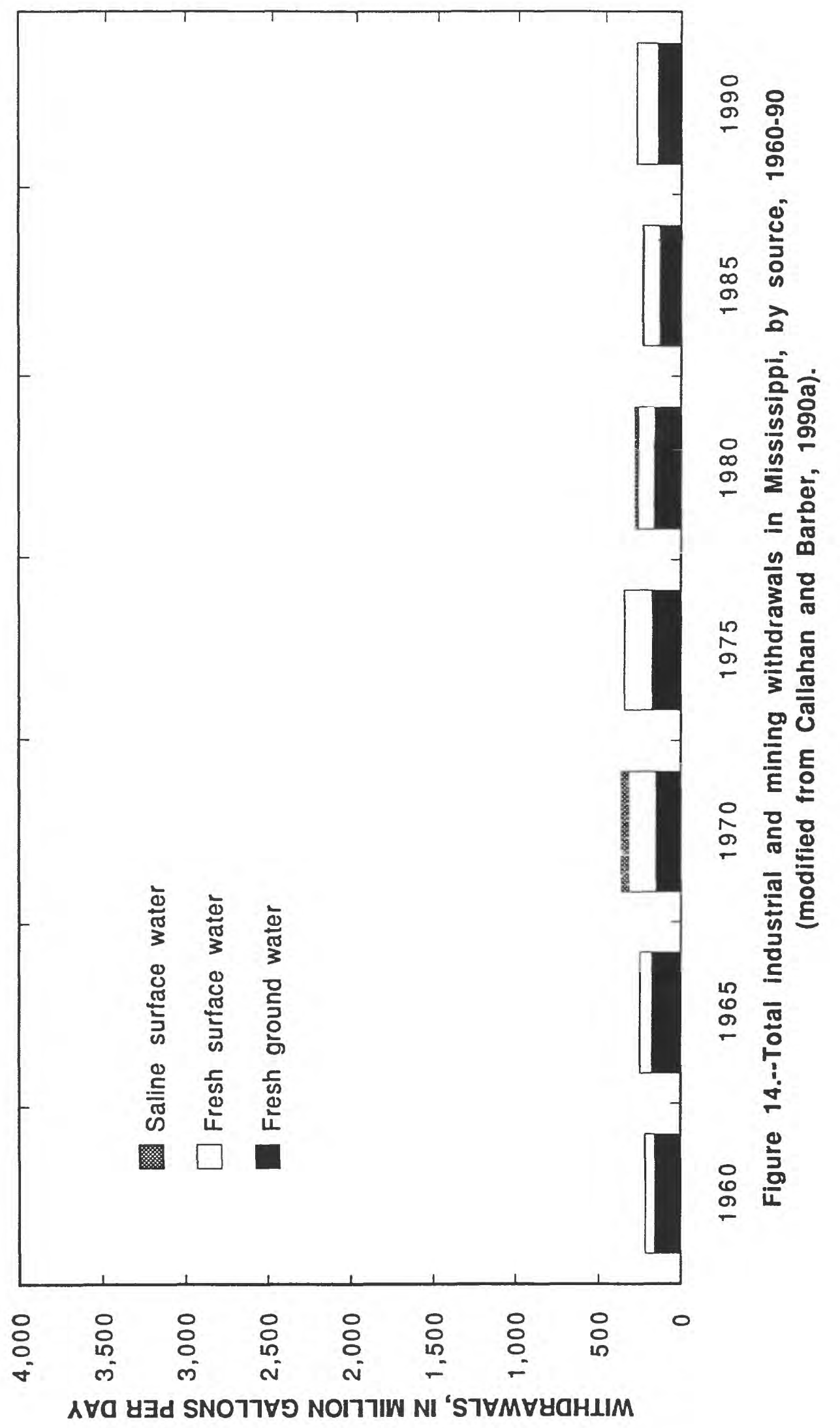




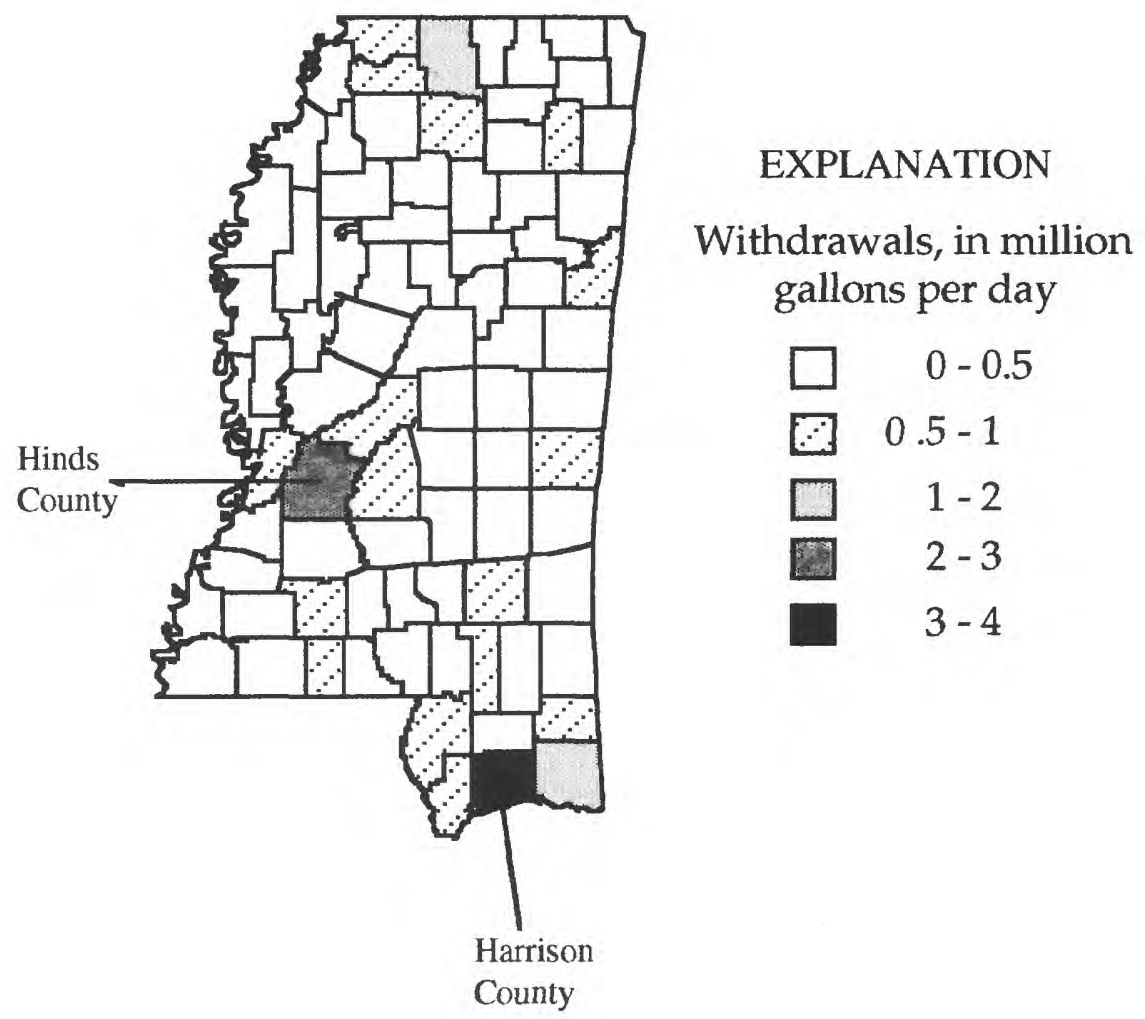

Figure 15.--Total domestic withdrawals in Mississippi, by county, 1990 . 


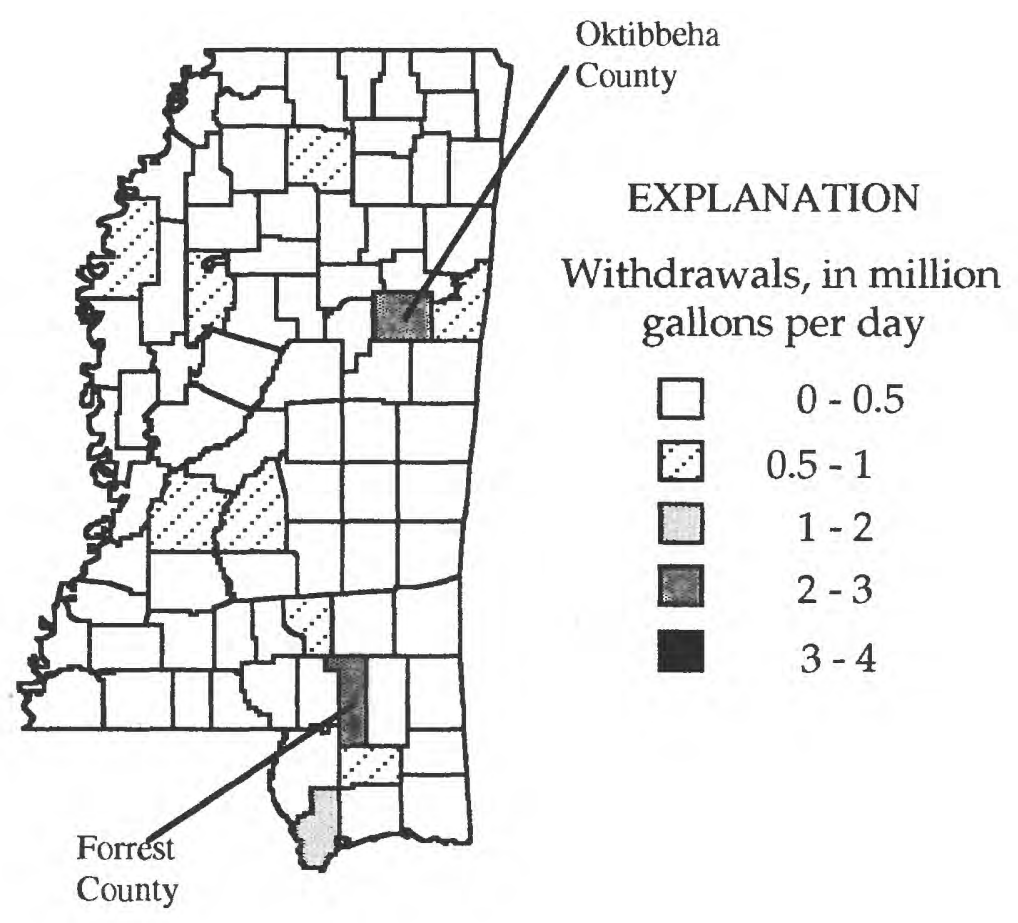

Figure 16.--Total commercial withdrawals in Mississippi, by county, 1990. 


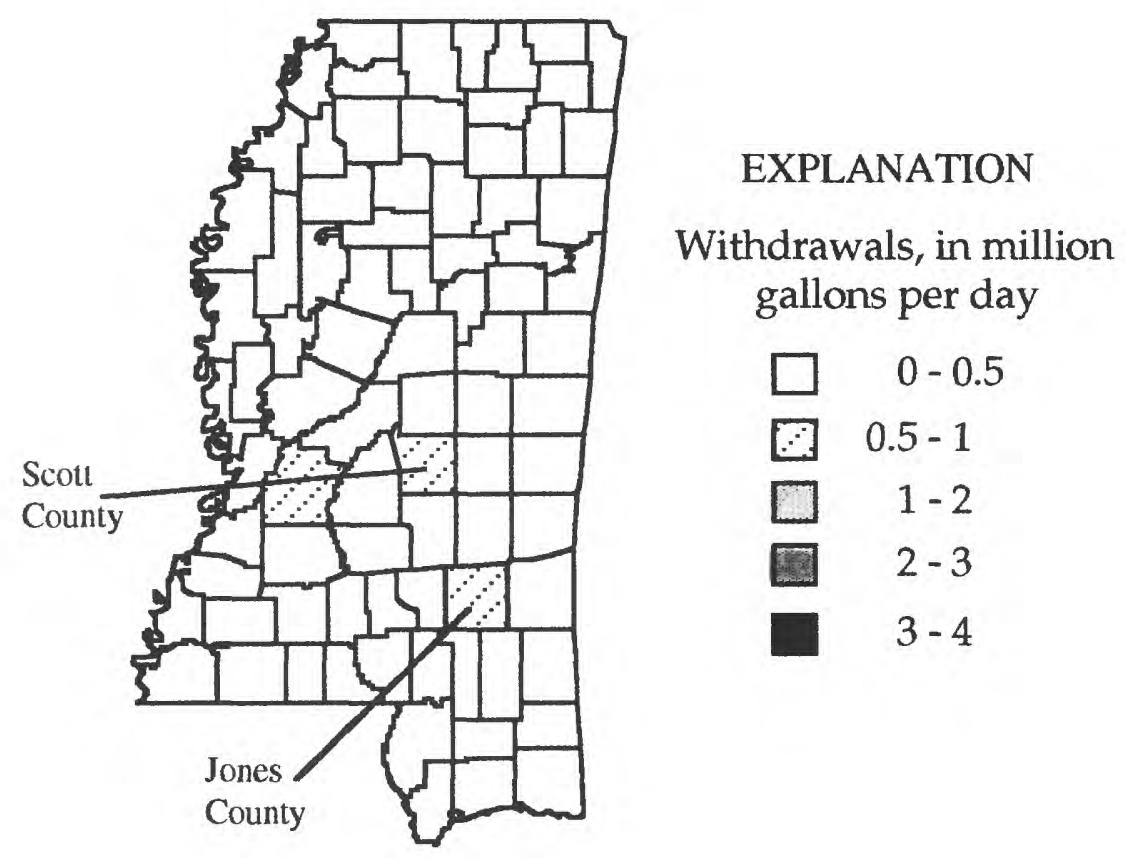

Figure 17.--Total livestock withdrawals in Mississippi, by county, 1990. 


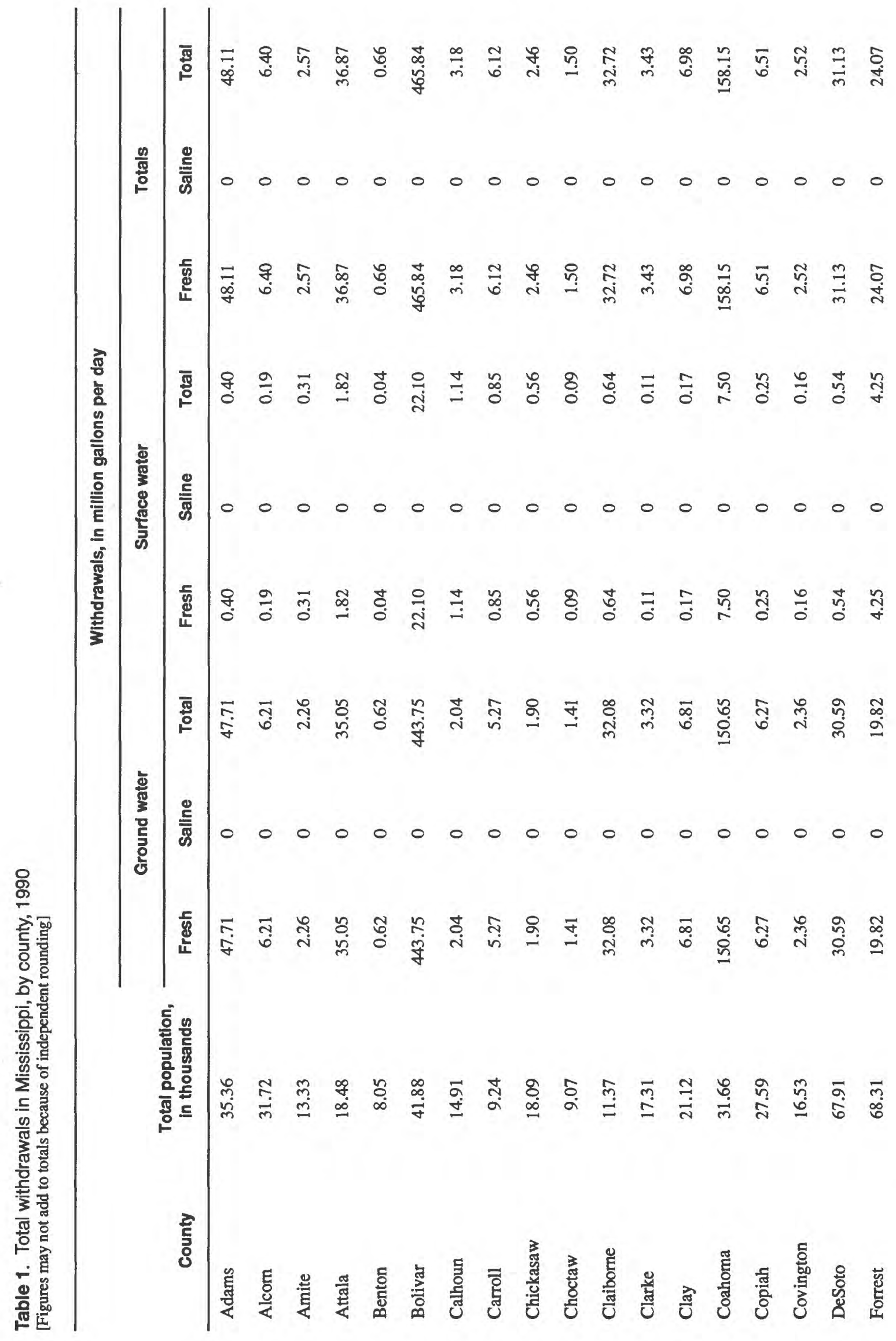




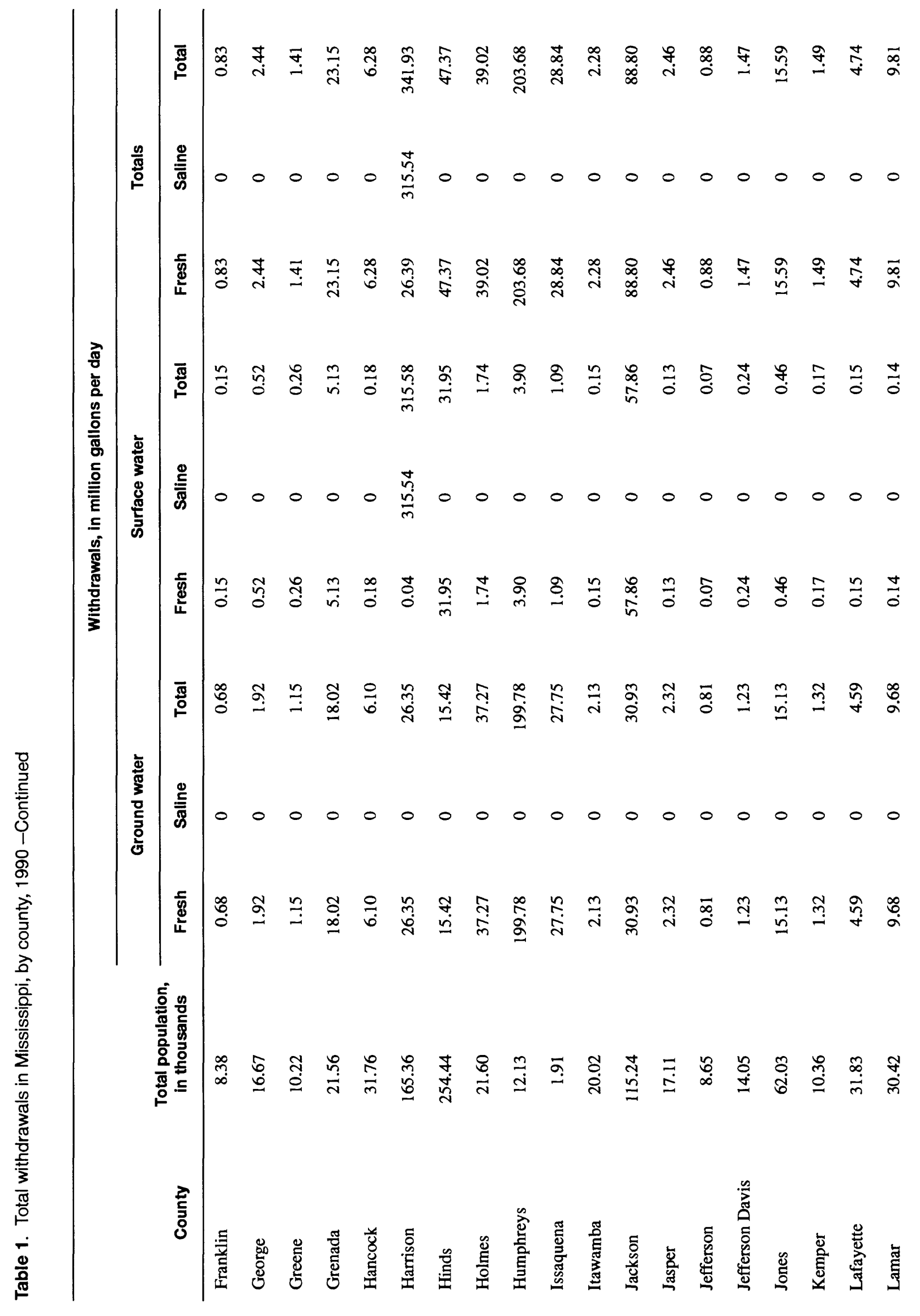




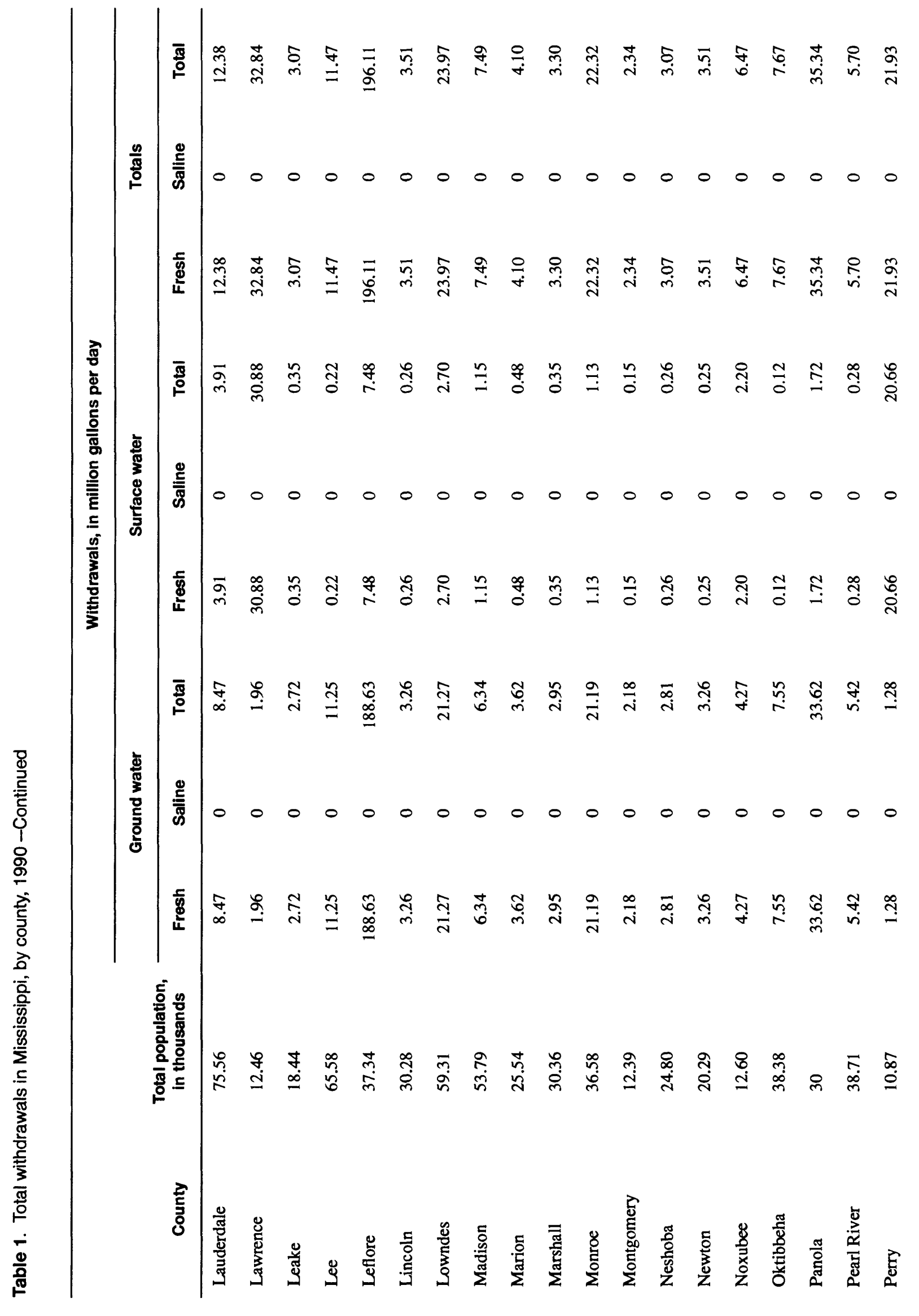




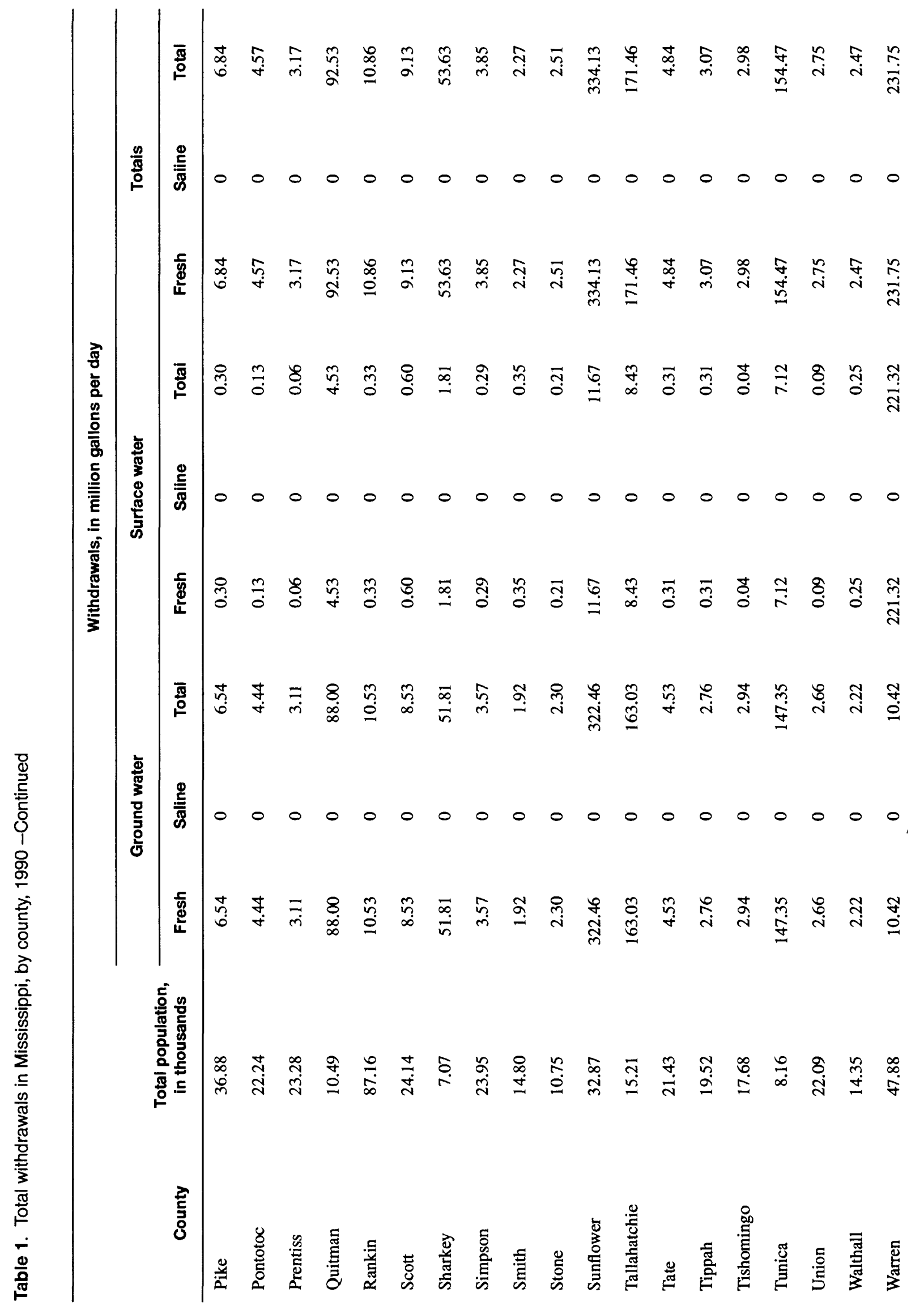




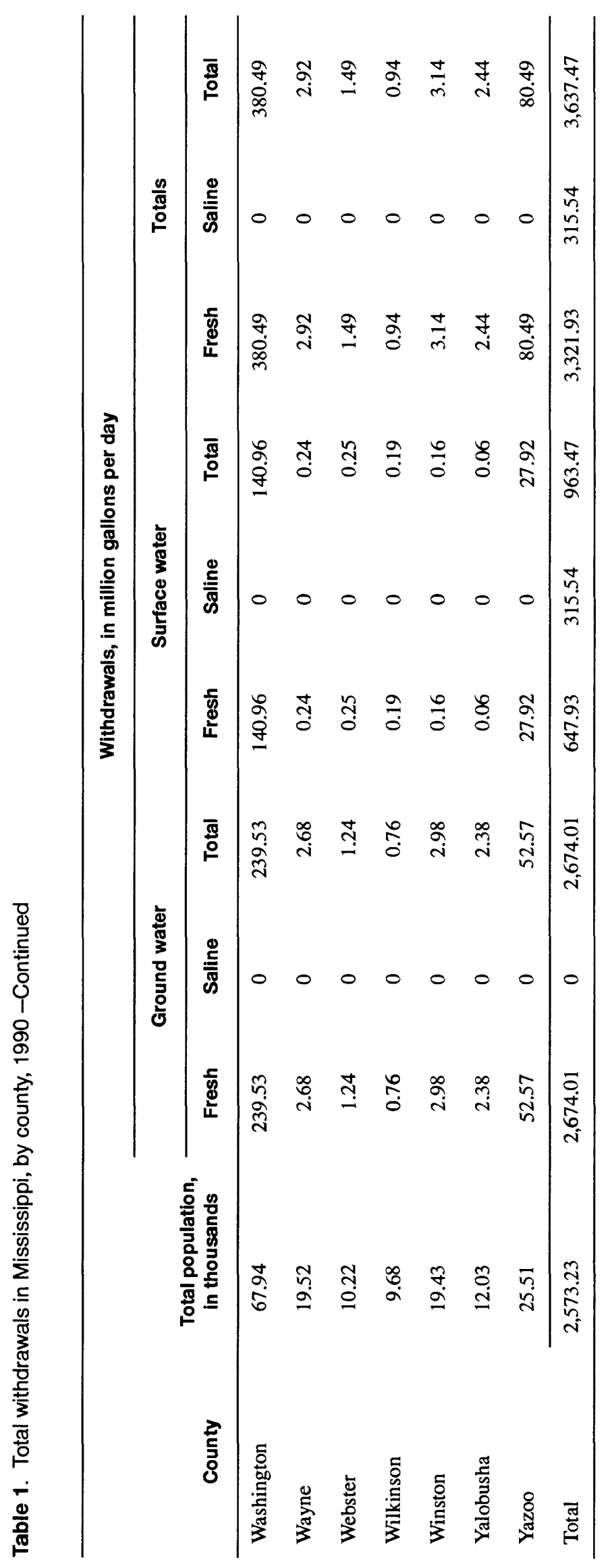




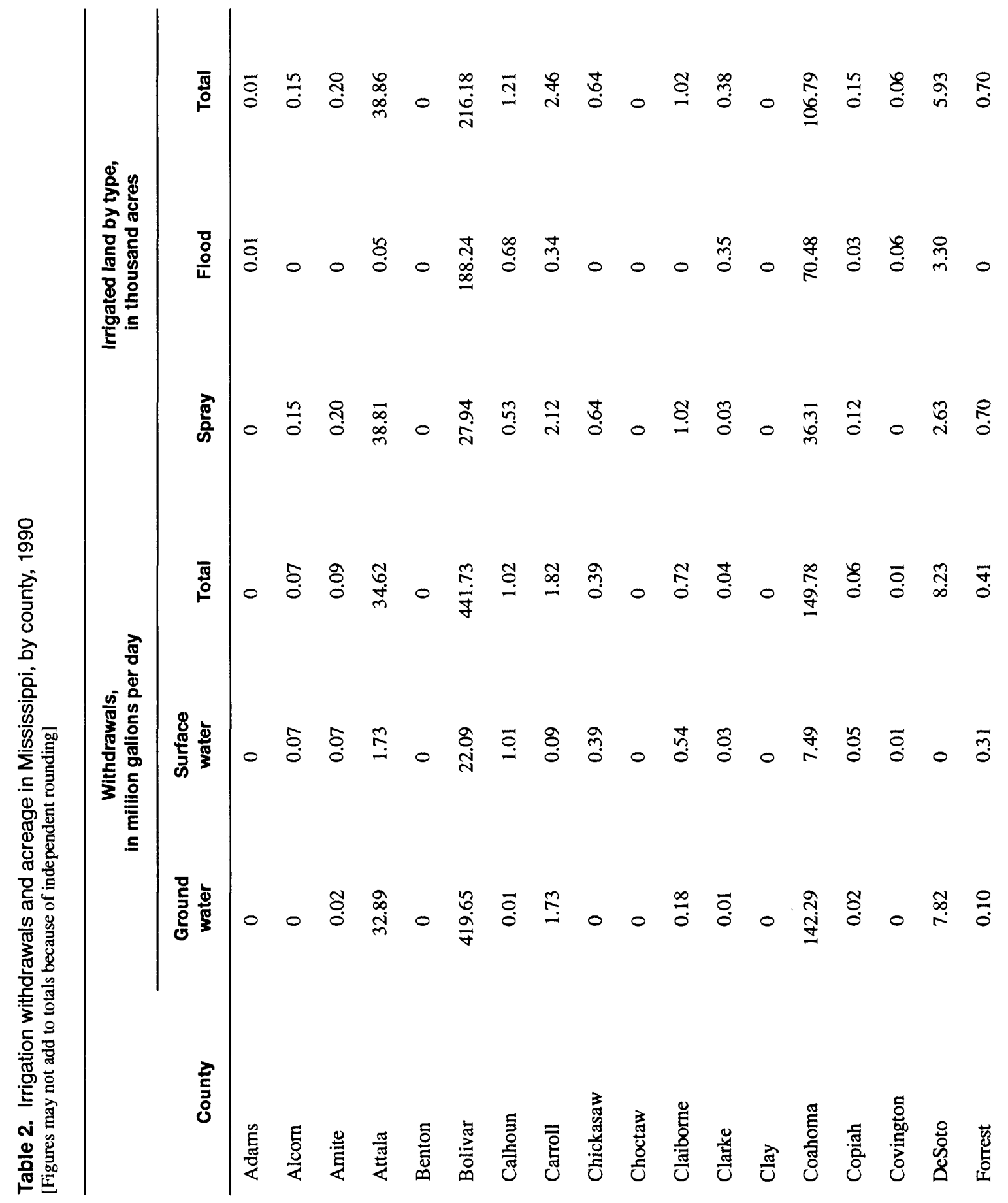




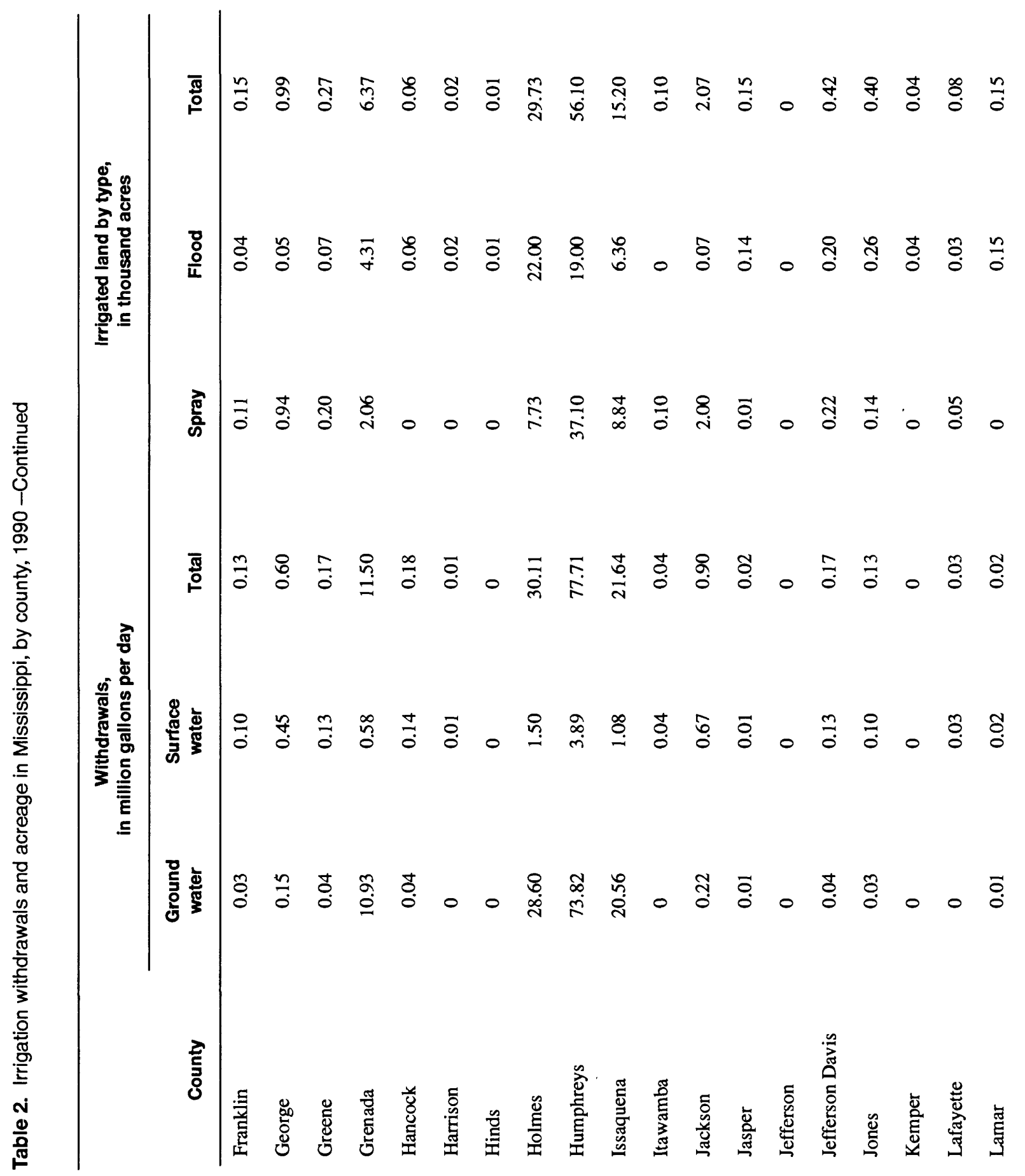




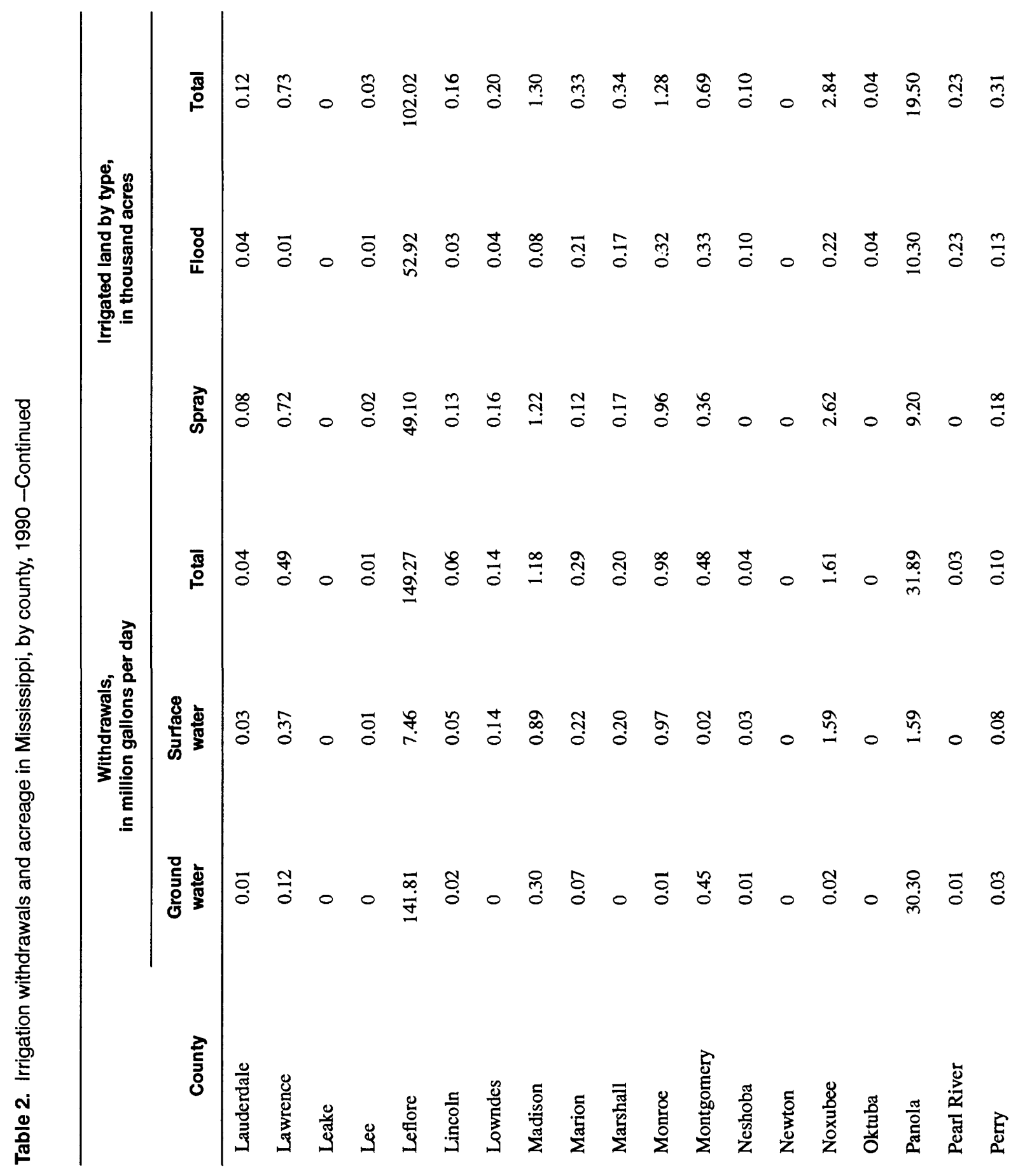




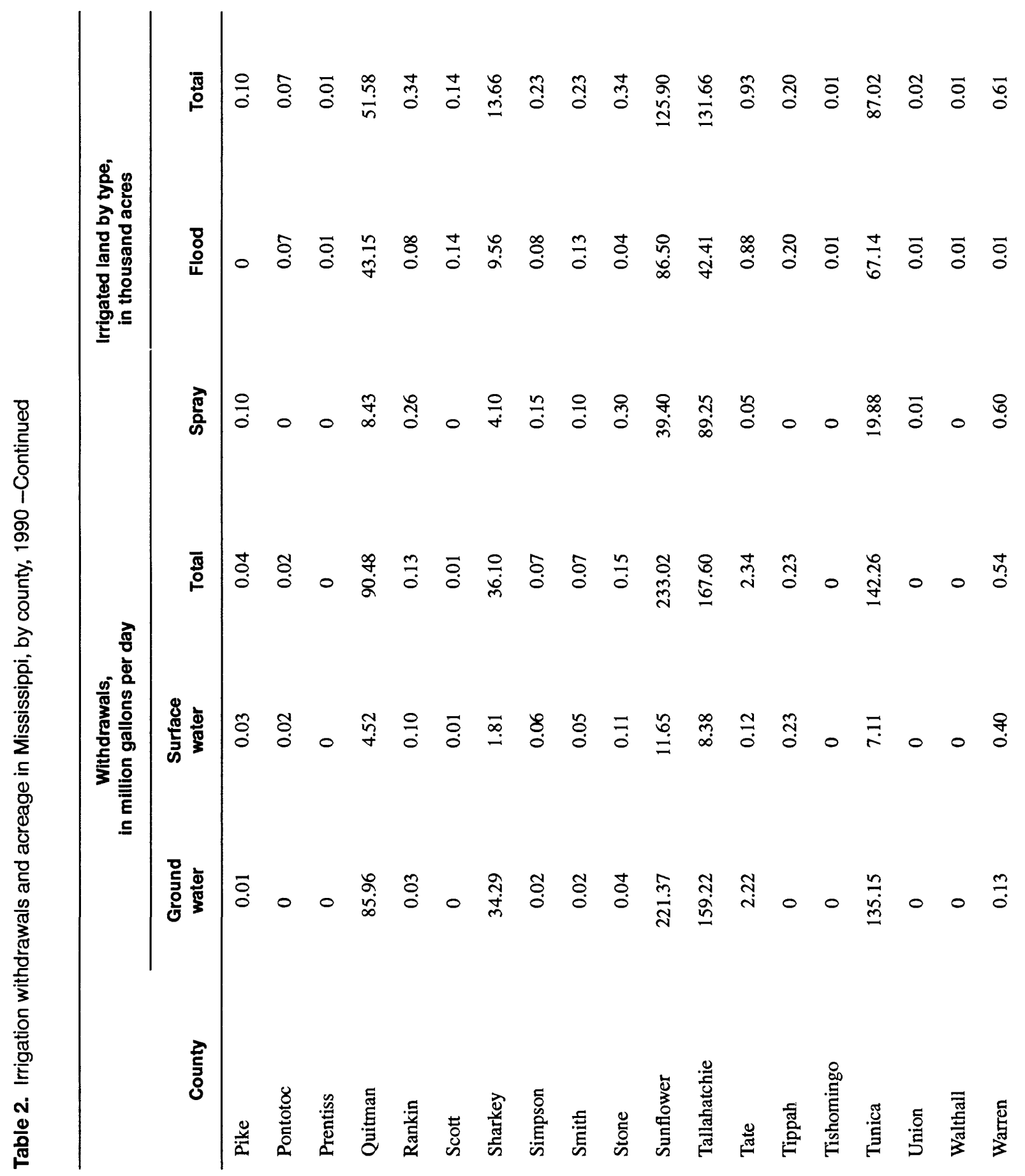




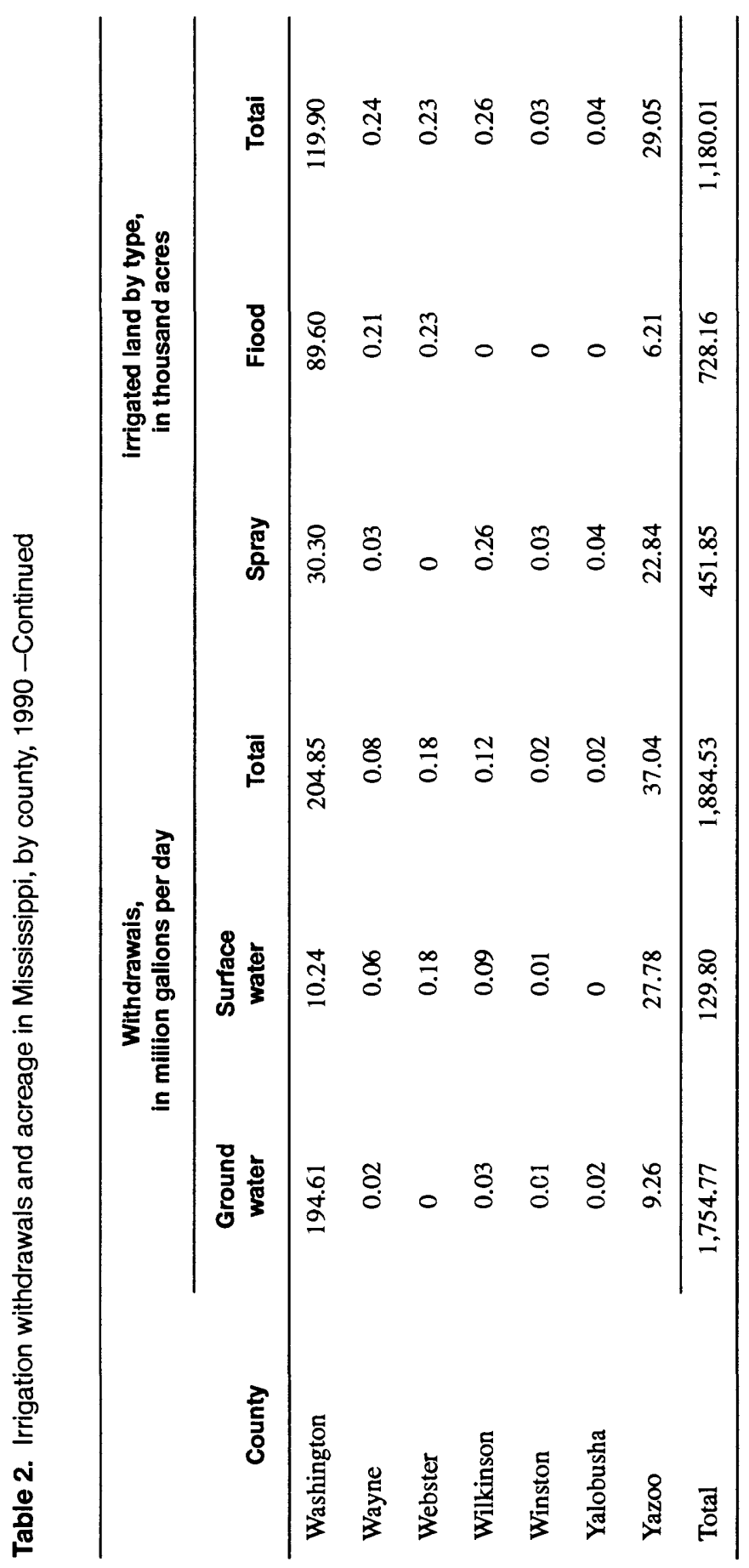




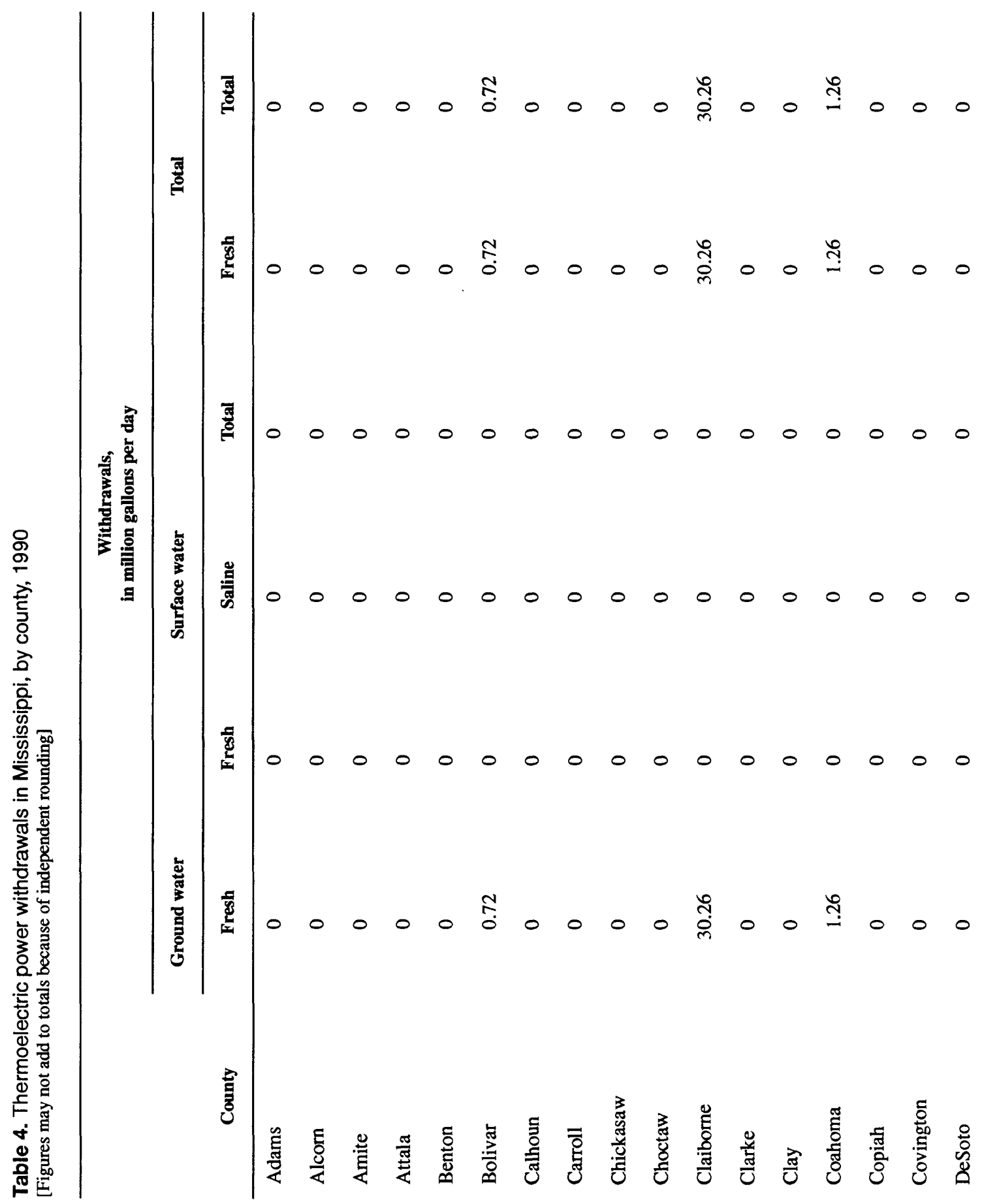




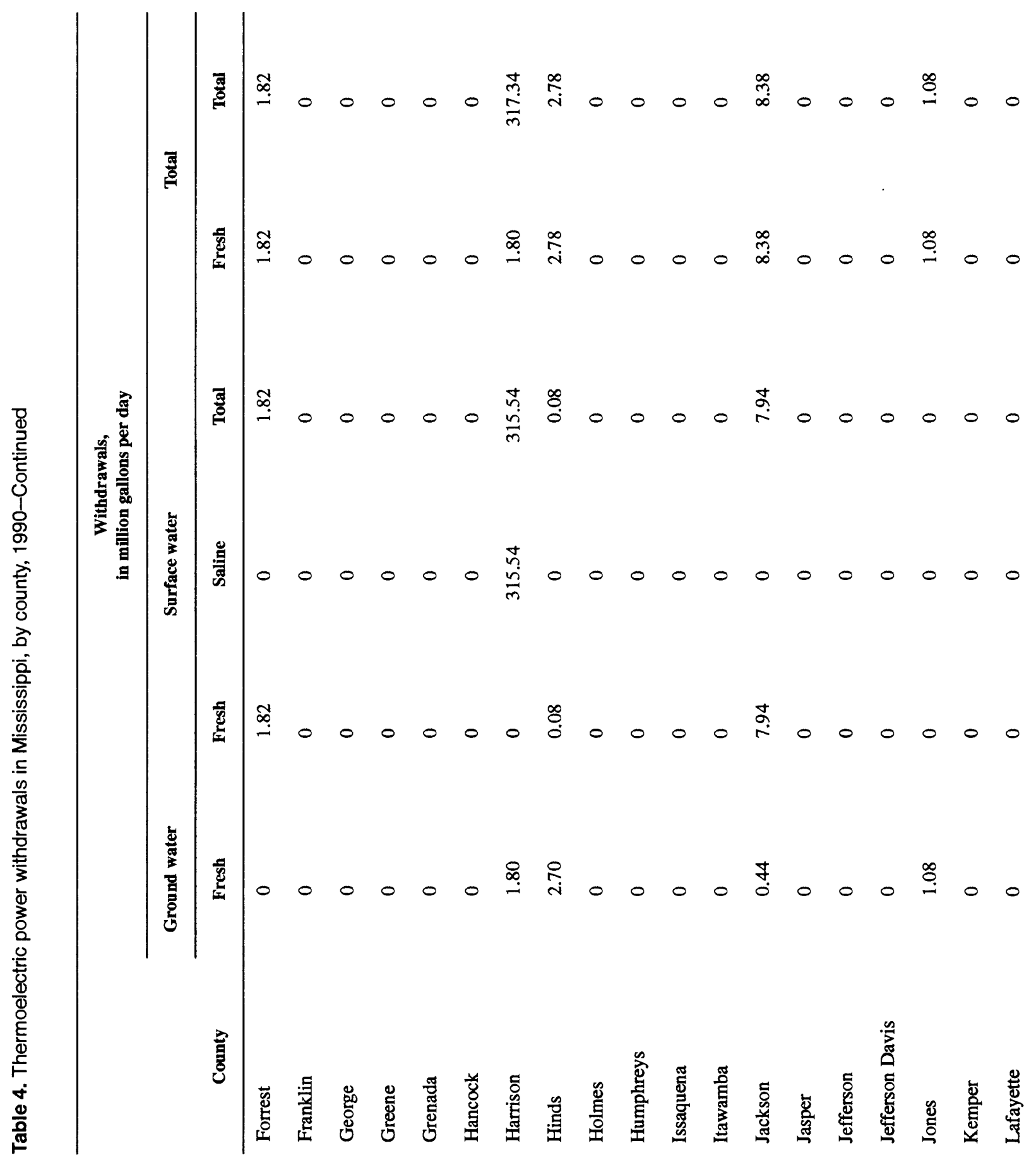




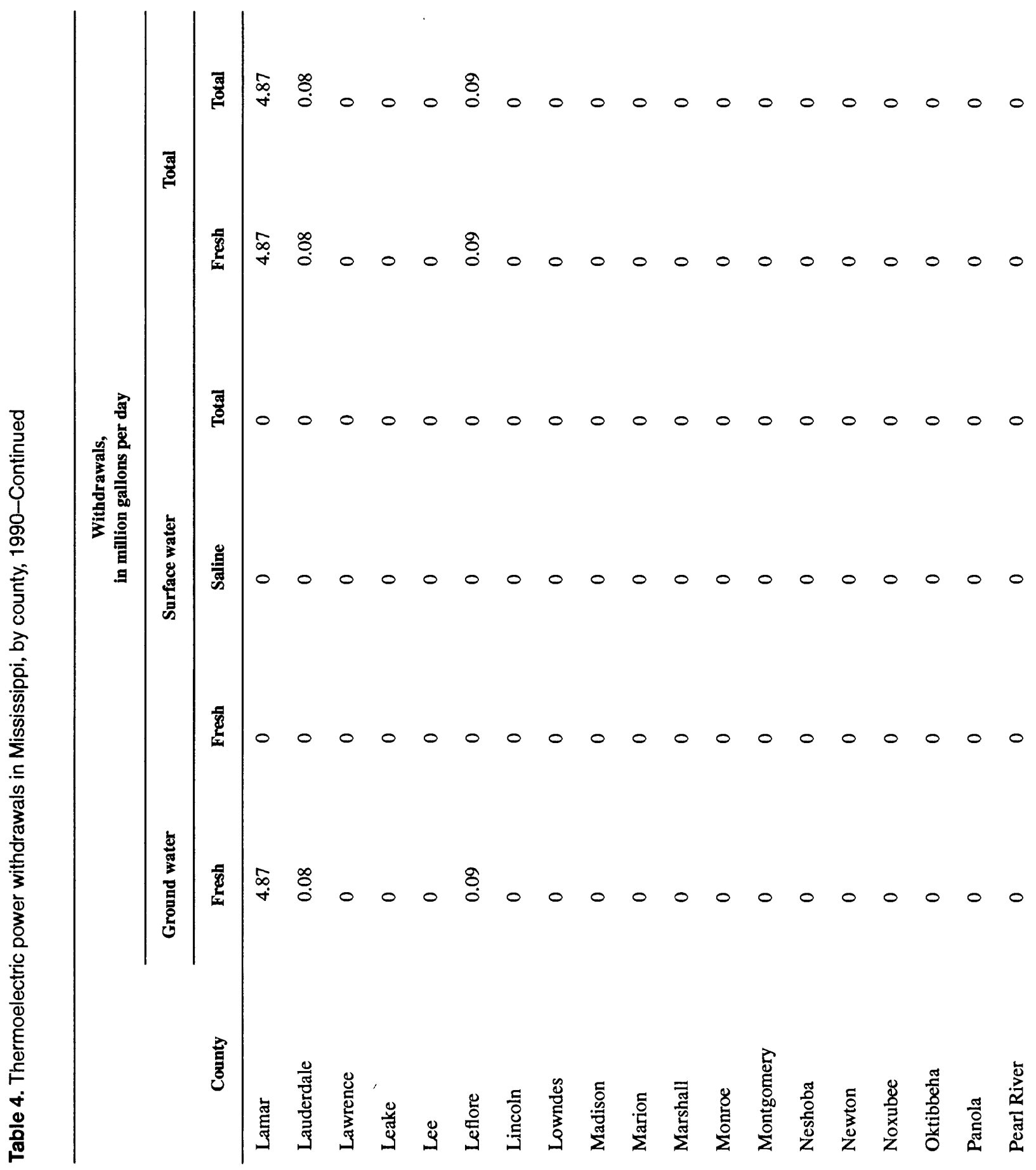




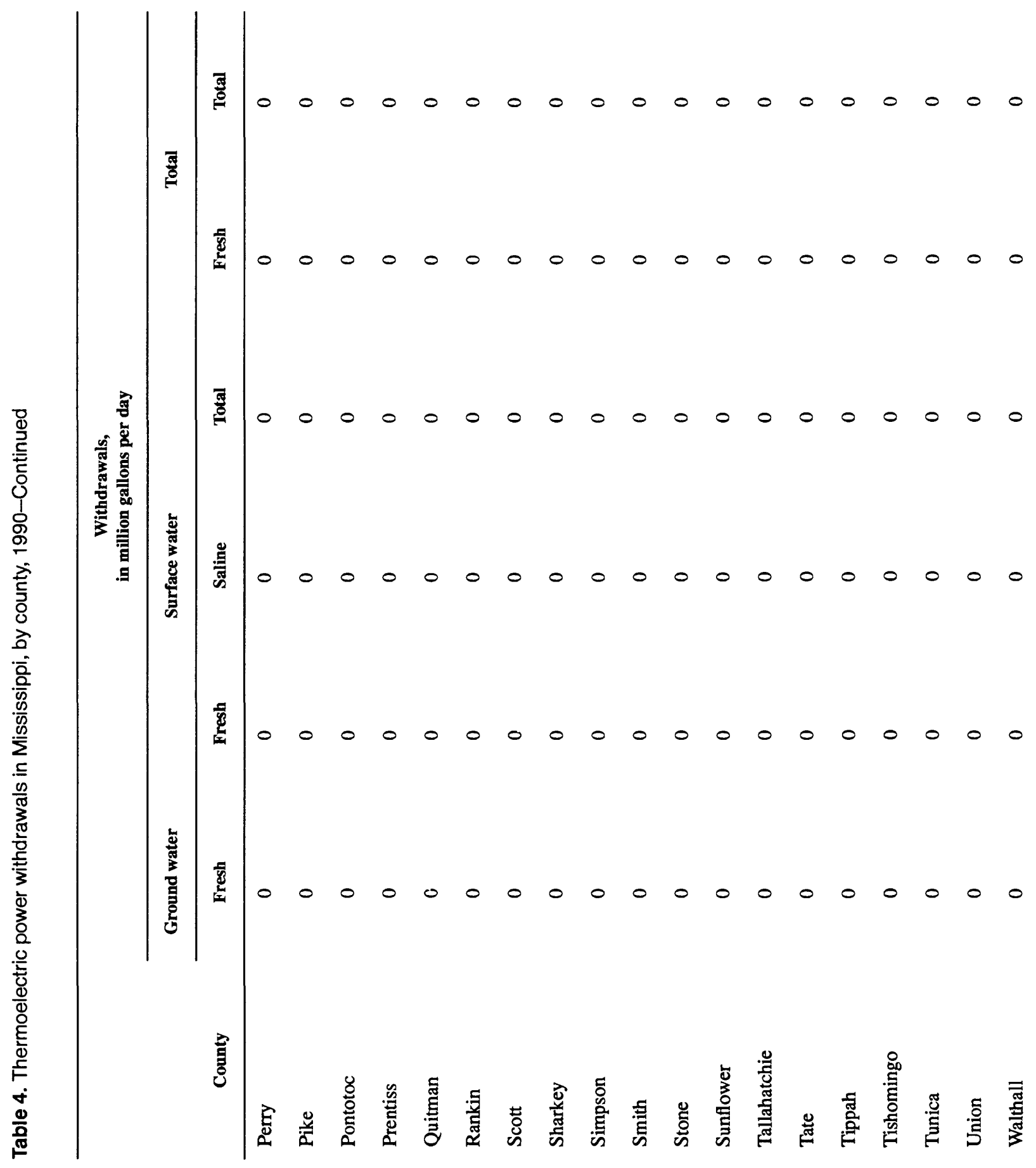




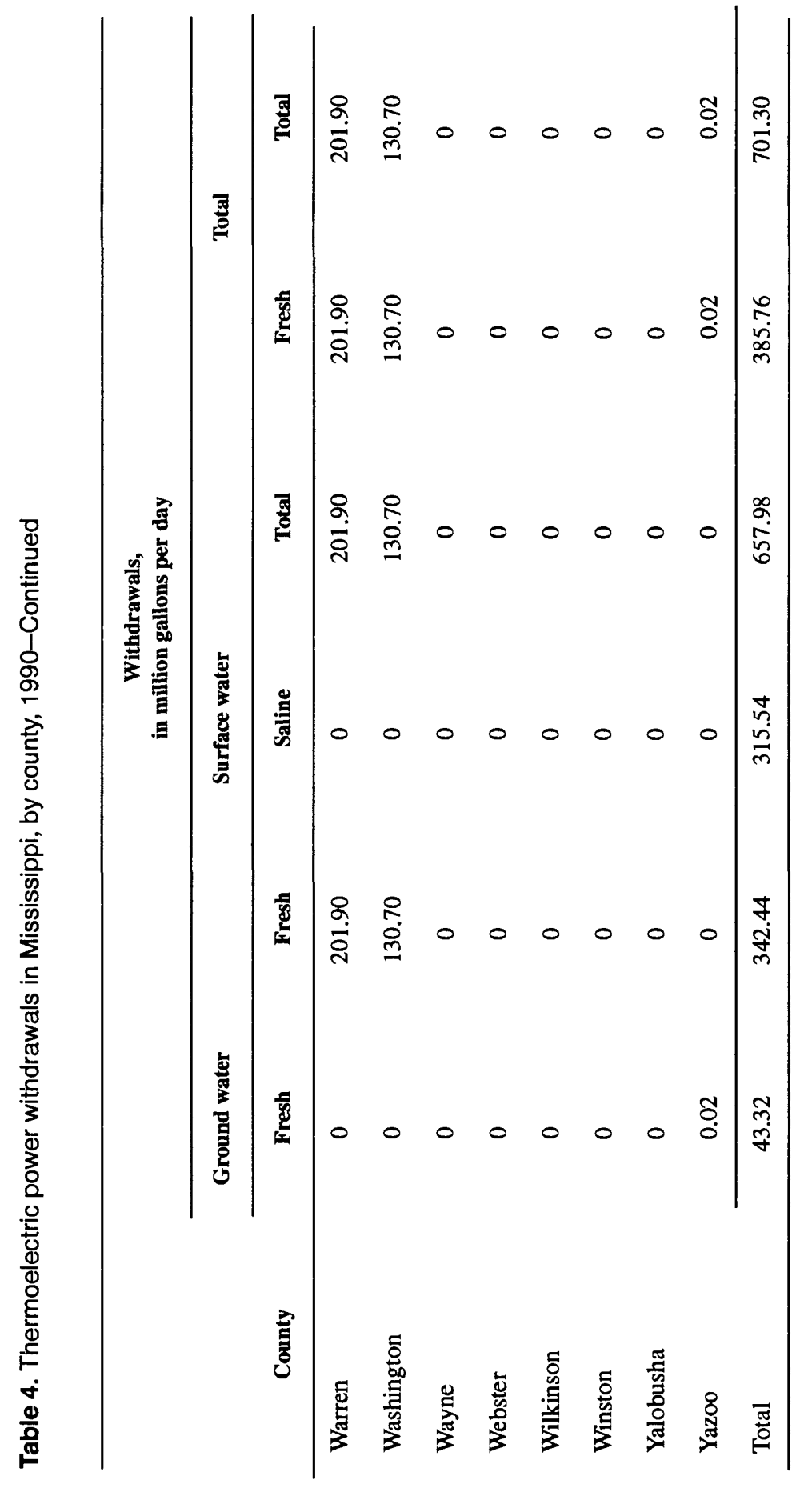


Table 6. Aquaculture withdrawals in Mississippi, by county, 1990

[Figures may not add to totals because of independent rounding]

\begin{tabular}{|c|c|c|c|}
\hline \multirow[b]{2}{*}{ County } & \multicolumn{3}{|c|}{$\begin{array}{c}\text { Withdrawals, } \\
\text { In million gallons per day }\end{array}$} \\
\hline & $\begin{array}{l}\text { Ground } \\
\text { water }\end{array}$ & $\begin{array}{l}\text { Surface } \\
\text { water }\end{array}$ & Tota \\
\hline Adams & 0 & 0 & 0 \\
\hline Alcorn & 0.40 & 0.07 & 0.47 \\
\hline Amite & 0.14 & 0.02 & 0.16 \\
\hline Attala & 0.02 & 0 & 0.02 \\
\hline Benton & 0 & 0 & 0 \\
\hline Bolivar & 13.96 & 0 & 13.96 \\
\hline Calhoun & 0.24 & 0.04 & 0.28 \\
\hline Carroll & 2.77 & 0.48 & 3.25 \\
\hline Chickasaw & 0.07 & 0.01 & 0.08 \\
\hline Choctaw & 0.16 & 0.03 & 0.19 \\
\hline Claiborne & 0 & 0 & 0 \\
\hline Clarke & 0.02 & 0 & 0.02 \\
\hline Clay & 0.07 & 0.01 & 0.08 \\
\hline Coahoma & 0.35 & 0 & 0.35 \\
\hline Copiah & 0 & 0 & 0 \\
\hline Covington & 0.10 & 0.02 & 0.12 \\
\hline DeSoto & 0 & 0 & 0 \\
\hline Forrest & 0.35 & 0.06 & 0.41 \\
\hline Franklin & 0 & 0 & 0 \\
\hline George & 0.08 & 0.02 & 0.10 \\
\hline Greene & 0.28 & 0.05 & 0.33 \\
\hline Grenada & 1.19 & 0 & 1.19 \\
\hline Hancock & 0 & 0 & 0 \\
\hline Harrison & 0 & 0 & 0 \\
\hline Hinds & 0 & 0 & 0 \\
\hline Holmes & 5.87 & 0 & 5.87 \\
\hline Humphreys & 124.23 & 0 & 124.23 \\
\hline
\end{tabular}


Table 6. Aquaculture withdrawals in Mississippi, by county, 1990-Continued

\begin{tabular}{|c|c|c|c|}
\hline \multirow[b]{2}{*}{ County } & \multicolumn{3}{|c|}{$\begin{array}{l}\text { Withdrawals, } \\
\text { in million gallons per day }\end{array}$} \\
\hline & $\begin{array}{l}\text { Ground } \\
\text { water }\end{array}$ & $\begin{array}{c}\text { Surface } \\
\text { water }\end{array}$ & Total \\
\hline Issaquena & 7.05 & 0 & 7.05 \\
\hline Itawamba & 0.08 & 0.02 & 0.10 \\
\hline Jackson & 0 & 0 & 0 \\
\hline Jasper & 0.07 & 0.01 & 0.08 \\
\hline Jefferson & 0 & 0 & 0 \\
\hline Jefferson Davis & 0 & 0 & 0 \\
\hline Jones & 0.30 & 0.05 & 0.35 \\
\hline Kemper & 0.27 & 0.05 & 0.32 \\
\hline Lafayette & 0 & 0 & 0 \\
\hline Lamar & 0.04 & 0.01 & 0.05 \\
\hline Lauderdale & 0 & 0 & 0 \\
\hline Lawrence & 0.35 & 0.06 & 0.41 \\
\hline Leake & 0.71 & 0.13 & 0.84 \\
\hline Lee & 0.43 & 0.08 & 0.51 \\
\hline Leflore & 44.11 & 0 & 44.11 \\
\hline Lincoln & 0 & 0 & 0 \\
\hline Lowndes & 0.23 & 0.04 & 0.27 \\
\hline Madison & 0.60 & 0.11 & 0.71 \\
\hline Marion & 0.57 & 0.10 & 0.67 \\
\hline Marshall & 0 & 0 & 0 \\
\hline Monroe & 0.09 & 0.02 & 0.11 \\
\hline Montgomery & 0.25 & 0.04 & 0.29 \\
\hline Neshoba & 0.03 & 0.01 & 0.04 \\
\hline Newton & 0.23 & 0.04 & 0.27 \\
\hline Noxubee & 2.47 & 0.43 & 2.90 \\
\hline Oktibbeha & 0 & 0 & 0 \\
\hline Panola & 0 & 0 & 0 \\
\hline Pearl River & 0.02 & 0 & 0.02 \\
\hline Perry & 0.09 & 0.02 & 0.11 \\
\hline
\end{tabular}


Table 6. Aquaculture withdrawals in Mississippi, by county, 1990--Continued

\begin{tabular}{|c|c|c|c|}
\hline \multirow[b]{2}{*}{ County } & \multicolumn{3}{|c|}{$\begin{array}{l}\text { Withdrawals, } \\
\text { In million gallons per day }\end{array}$} \\
\hline & $\begin{array}{l}\text { Ground } \\
\text { water }\end{array}$ & $\begin{array}{l}\text { Surface } \\
\text { water }\end{array}$ & Total \\
\hline Pike & 0.34 & 0.06 & 0.40 \\
\hline Pontotoc & 0.07 & 0.01 & 0.08 \\
\hline Prentiss & 0 & 0 & 0 \\
\hline Quitman & 0.71 & 0 & 0.71 \\
\hline Rankin & 0.20 & 0.03 & 0.23 \\
\hline Scott & 1.03 & 0.18 & 1.21 \\
\hline Sharkey & 16.82 & 0 & 16.82 \\
\hline Simpson & 0 & 0 & 0 \\
\hline Smith & 0.04 & 0.01 & 0.05 \\
\hline Stone & 0.21 & 0.04 & 0.25 \\
\hline Sunflower & 95.02 & 0 & 95.02 \\
\hline Tallahatchie & 2.45 & 0 & 2.45 \\
\hline Tate & 0.05 & 0.01 & 0.06 \\
\hline Tippah & 0 & 0 & 0 \\
\hline Tishomingo & 0 & 0 & 0 \\
\hline Tunica & 11.35 & 0 & 11.35 \\
\hline Union & 0.04 & 0.01 & 0.05 \\
\hline Walthall & 0.07 & 0.01 & 0.08 \\
\hline Warren & 0 & 0 & 0 \\
\hline Washington & 33.10 & 0 & 33.10 \\
\hline Wayne & 0.10 & 0.02 & 0.12 \\
\hline Webster & 0.05 & 0.01 & 0.06 \\
\hline Wilkinson & 0 & 0 & 0 \\
\hline Winston & 0.14 & 0.02 & 0.16 \\
\hline Yalobusha & 0 & 0 & 0 \\
\hline Yazoo & 22.66 & 0 & 22.66 \\
\hline Total & 392.74 & 2.44 & 395.18 \\
\hline
\end{tabular}




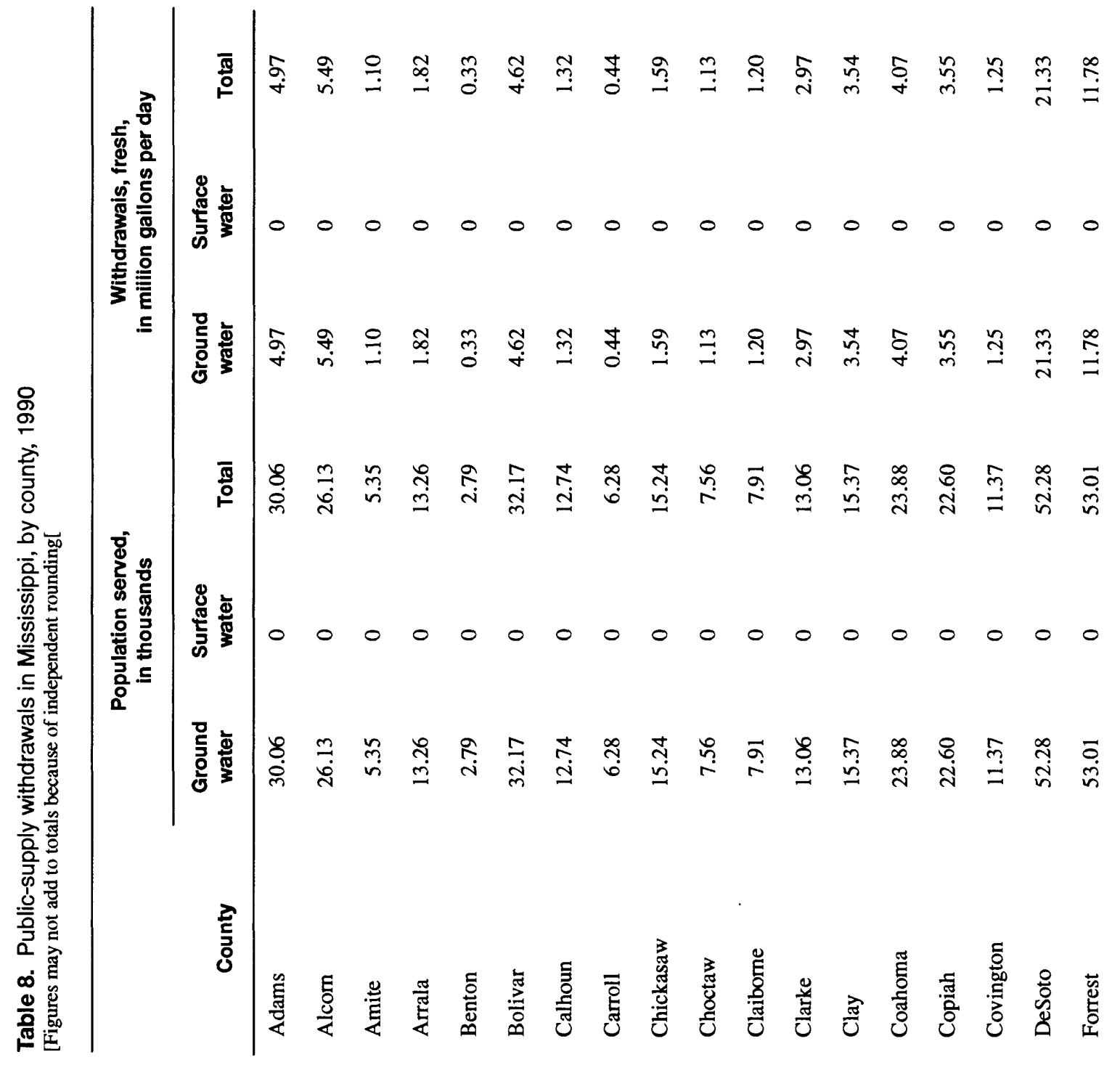




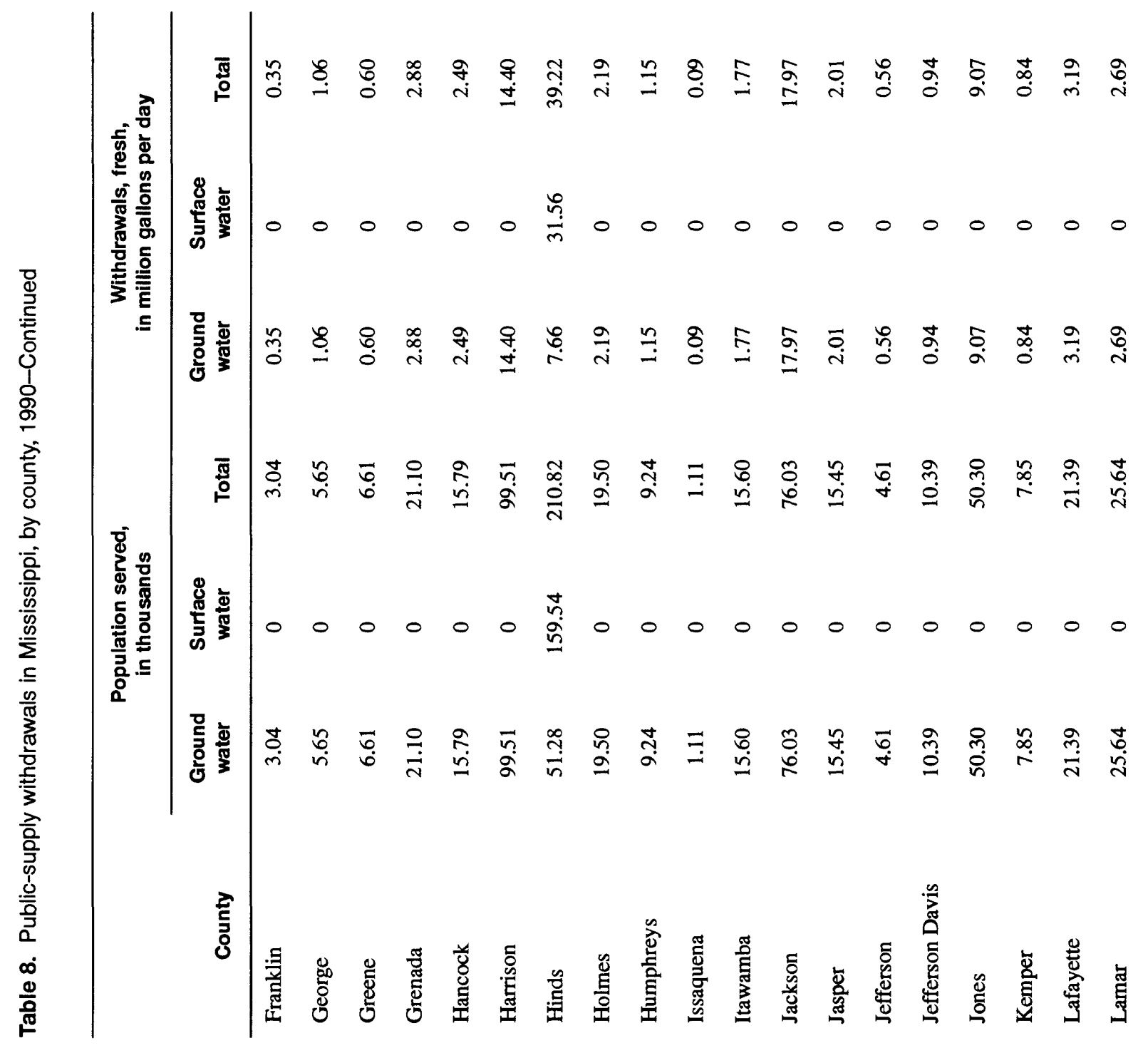




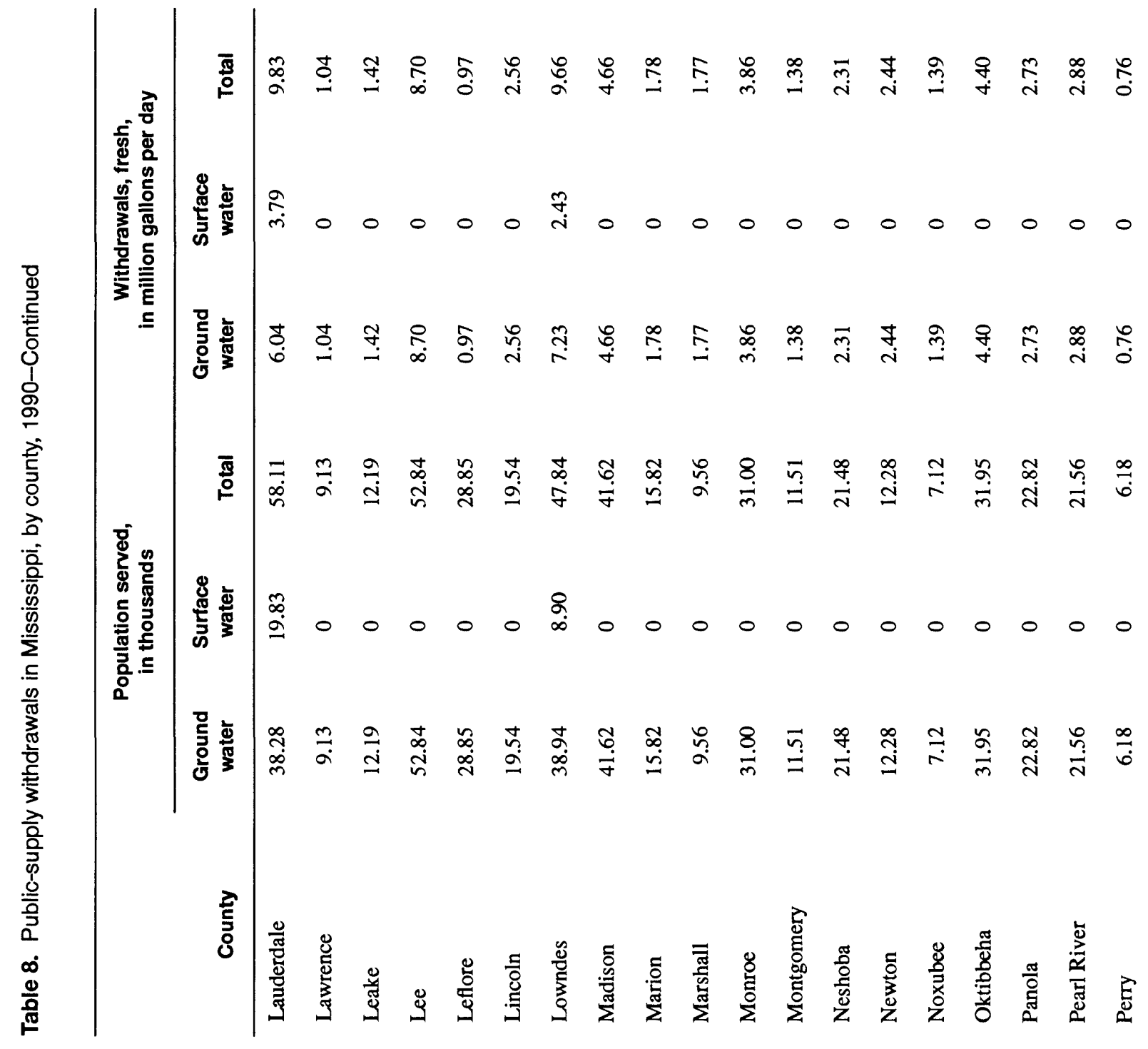




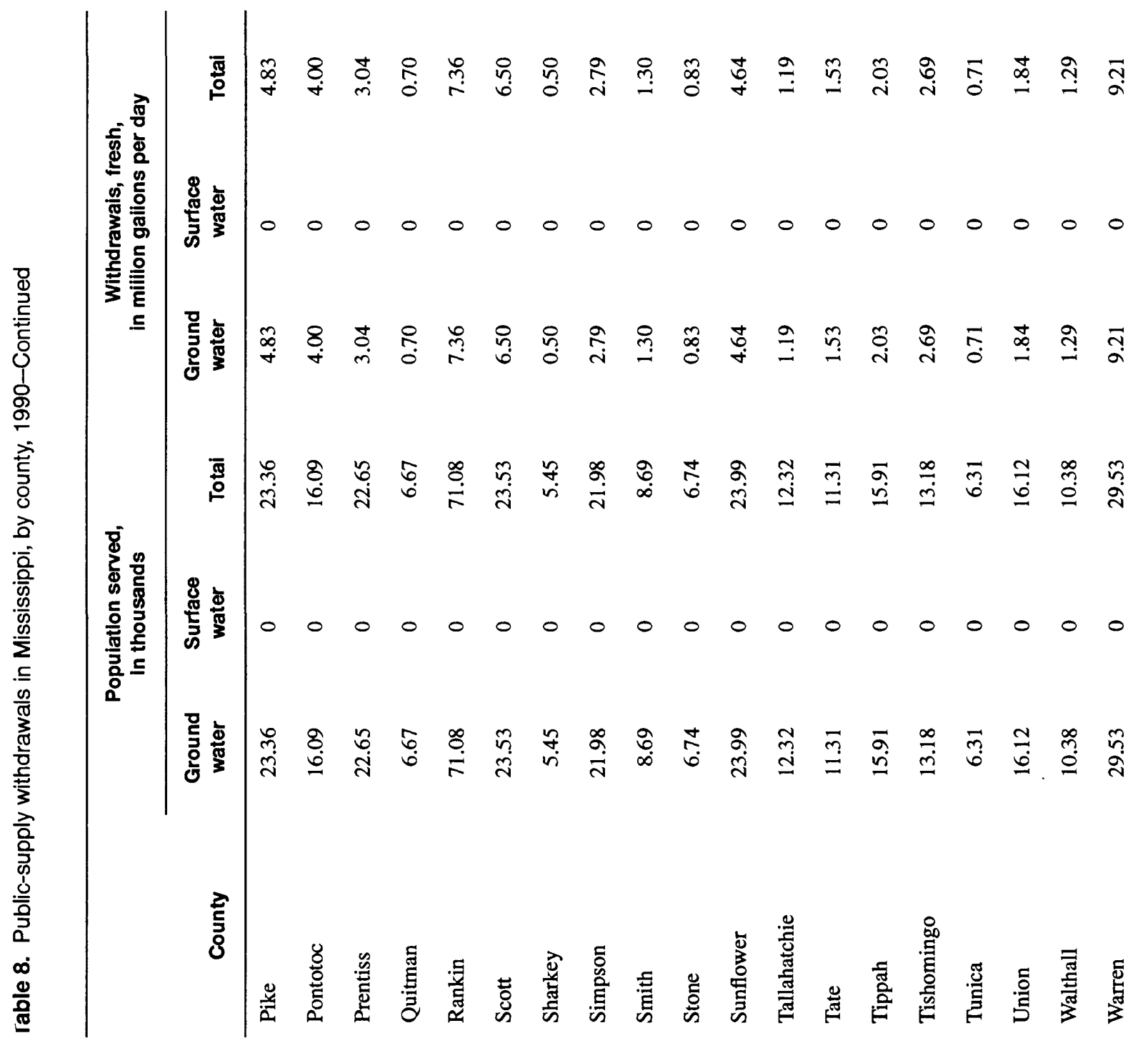




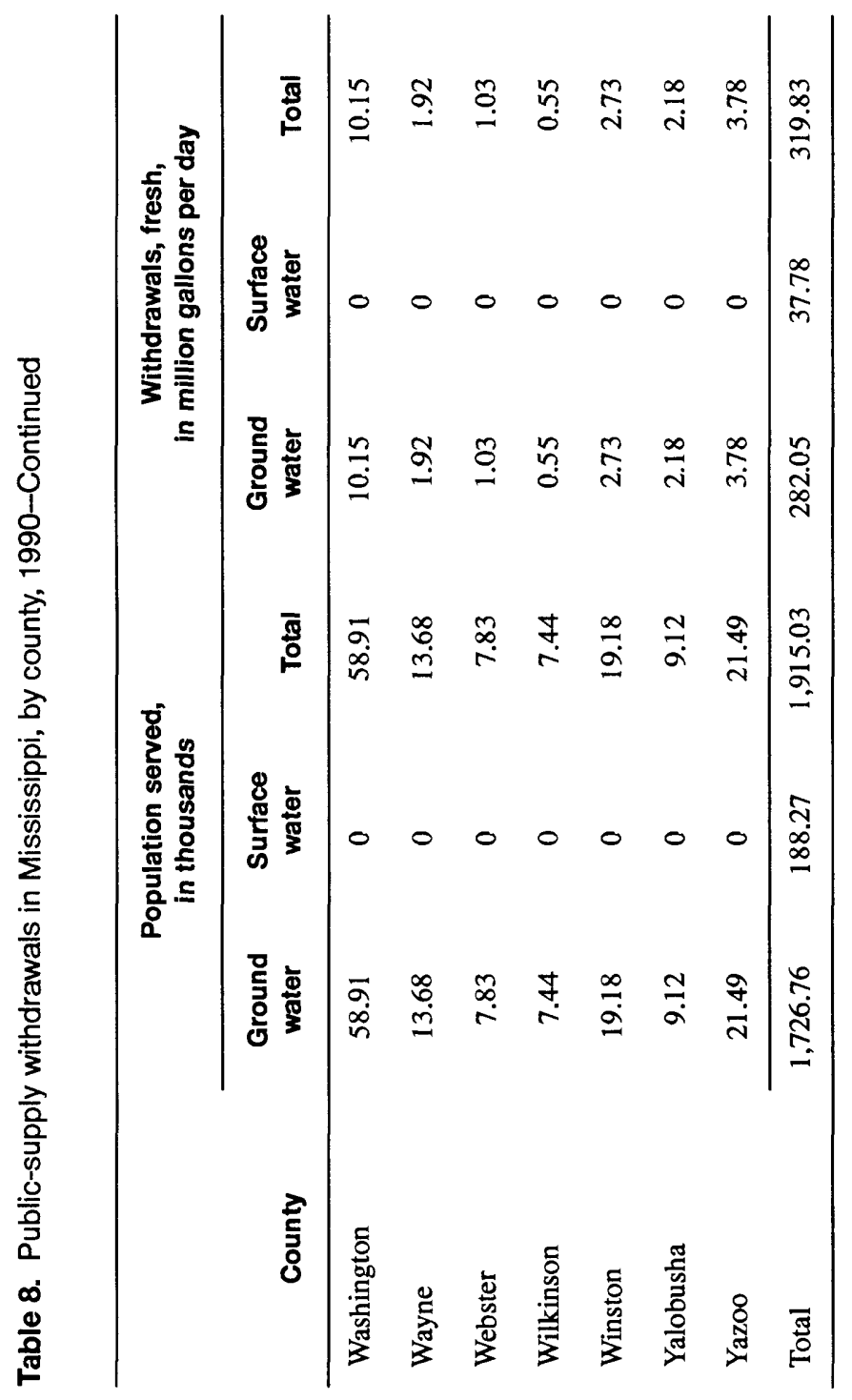


Table 9. Industrial and mining withdrawals in Mississippi, by county, 1990 [Figures may not add to totals because of independent rounding]

\begin{tabular}{|c|c|c|c|}
\hline \multirow[b]{3}{*}{ County } & \multicolumn{3}{|c|}{$\begin{array}{l}\text { Wlthdrawals, } \\
\text { in million gallons per day }\end{array}$} \\
\hline & \multicolumn{2}{|c|}{ Fresh } & \multirow[b]{2}{*}{ Total } \\
\hline & $\begin{array}{l}\text { Ground } \\
\text { water }\end{array}$ & $\begin{array}{c}\text { Surface } \\
\text { water }\end{array}$ & \\
\hline Adams & 42.45 & 0.37 & 42.82 \\
\hline Alcorn & 0 & 0 & 0 \\
\hline Amite & 0.45 & 0 & 0.45 \\
\hline Attala & 0 & 0 & 0 \\
\hline Benton & 0 & 0 & 0 \\
\hline Bolivar & 3.41 & 0 & 3.41 \\
\hline Calhoun & 0.30 & 0 & 0.30 \\
\hline Carroll & 0 & 0 & 0 \\
\hline Chickasaw & 0 & 0 & 0 \\
\hline Choctaw & 0 & 0 & 0 \\
\hline Claiborne & 0.03 & 0 & 0.03 \\
\hline Clarke & 0.06 & 0 & 0.06 \\
\hline Clay & 2.80 & 0 & 2.80 \\
\hline Coahoma & 2.04 & 0 & 2.04 \\
\hline Copiah & 2.31 & 0 & 2.31 \\
\hline Covington & 0.02 & 0 & 0.02 \\
\hline DeSoto & 0.58 & 0 & 0.58 \\
\hline Forrest & 4.67 & 2.00 & 6.67 \\
\hline Franklin & 0 & 0 & 0 \\
\hline George & 0.04 & 0 & 0.04 \\
\hline Greene & 0 & 0 & 0 \\
\hline Grenada & 2.94 & 4.48 & 7.42 \\
\hline Hancock & 1.04 & 0 & 1.04 \\
\hline Harrison & 6.40 & 0 & 6.40 \\
\hline Hinds & 1.70 & 0.01 & 1.71 \\
\hline Holmes & 0.43 & 0.13 & 0.56 \\
\hline
\end{tabular}


Table 9. Industrial and mining withdrawals in Mississippi, by county, 1990-Continued

\begin{tabular}{|c|c|c|c|}
\hline \multirow[b]{3}{*}{ County } & \multicolumn{3}{|c|}{$\begin{array}{l}\text { Withdrawals, } \\
\text { In million gallons per day }\end{array}$} \\
\hline & \multicolumn{2}{|c|}{ Fresh } & \multirow[b]{2}{*}{ Total } \\
\hline & $\begin{array}{l}\text { Ground } \\
\text { water }\end{array}$ & $\begin{array}{l}\text { Surface } \\
\text { water }\end{array}$ & \\
\hline Humphreys & 0.41 & 0 & 0.41 \\
\hline Issaquena & 0 & 0 & 0 \\
\hline Itawamba & 0 & 0 & 0 \\
\hline Jackson & 10.09 & 49.22 & 59.31 \\
\hline Jasper & 0.09 & 0 & 0.09 \\
\hline Jefferson & 0 & 0 & 0 \\
\hline Jefferson Davis & 0 & 0 & 0 \\
\hline Jones & 3.54 & 0 & 3.54 \\
\hline Kemper & 0 & 0 & 0 \\
\hline Lafayette & 0.01 & 0.04 & 0.05 \\
\hline Lamar & 1.70 & 0 & 1.70 \\
\hline Lauderdale & 0.91 & 0 & 0.91 \\
\hline Lawrence & 0.23 & 30.38 & 30.61 \\
\hline Leake & 0.13 & 0 & 0.13 \\
\hline Lee & 1.39 & 0 & 1.39 \\
\hline Leflore & 0.62 & 0 & 0.62 \\
\hline Lincoln & 0 & 0 & 0 \\
\hline Lowndes & 12.34 & 0 & 12.34 \\
\hline Madison & 0 & 0 & 0 \\
\hline Marion & 0.60 & 0 & 0.60 \\
\hline Marshall & 0.04 & 0 & 0.04 \\
\hline Monroe & 16.84 & 0 & 16.84 \\
\hline Montgomery & 0 & 0 & 0 \\
\hline Neshoba & 0.14 & 0 & 0.14 \\
\hline Newton & 0.05 & 0 & 0.05 \\
\hline Noxubee & 0 & 0 & 0 \\
\hline Oktibbeha & 0.72 & 0 & 0.72 \\
\hline Panola & 0.14 & 0 & 0.14 \\
\hline
\end{tabular}


Table 9. Industrial and mining withdrawals in Mississippi, by county, 1990-Continued

\begin{tabular}{|c|c|c|c|}
\hline \multirow[b]{3}{*}{ County } & \multicolumn{3}{|c|}{$\begin{array}{c}\text { Withdrawals, } \\
\text { in miliiion gailons per day }\end{array}$} \\
\hline & \multicolumn{2}{|c|}{ Fresh } & \multirow[b]{2}{*}{ Totai } \\
\hline & $\begin{array}{l}\text { Ground } \\
\text { water }\end{array}$ & $\begin{array}{c}\text { Surface } \\
\text { water }\end{array}$ & \\
\hline Pearl River & 1.47 & 0 & 1.47 \\
\hline Perry & 0.13 & 20.50 & 20.63 \\
\hline Pike & 0.28 & 0 & 0.28 \\
\hline Pontotoc & 0 & 0 & 0 \\
\hline Prentiss & 0 & 0 & 0 \\
\hline Quitman & 0.43 & 0 & 0.43 \\
\hline Rankin & 1.22 & 0 & 1.22 \\
\hline Scott & 0.70 & 0 & 0.70 \\
\hline Sharkey & 0.08 & 0 & 0.08 \\
\hline Simpson & 0.30 & 0 & 0.30 \\
\hline Smith & 0.07 & 0 & 0.07 \\
\hline Stone & 0.40 & 0 & 0.40 \\
\hline Sinflower & 0.71 & 0 & 0.71 \\
\hline Tallahatchie & 0 & 0 & 0 \\
\hline Tate & 0.10 & 0 & 0.10 \\
\hline Tippah & 0.40 & 0 & 0.40 \\
\hline Tishomingo & 0 & 0 & 0 \\
\hline Tunica & 0.04 & 0 & 0.04 \\
\hline Union & 0.40 & 0 & 0.40 \\
\hline Walthall & 0.11 & 0 & 0.11 \\
\hline Warren & 0.13 & 18.97 & 19.10 \\
\hline Washington & 1.09 & 0 & 1.09 \\
\hline Wayne & 0.19 & 0 & 0.19 \\
\hline Webster & 0 & 0 & 0 \\
\hline Wilkinson & 0 & 0 & 0 \\
\hline Winston & 0 & 0 & 0 \\
\hline
\end{tabular}


Table 9. Industrial and mining withdrawals in Mississippi, by county, 1990-Continued

\begin{tabular}{lccc}
\hline & \multicolumn{3}{c}{$\begin{array}{c}\text { Withdrawals, } \\
\text { in million gallons per day }\end{array}$} \\
\cline { 2 - 4 } \multicolumn{1}{c}{ County } & \multicolumn{3}{c}{ Fresh } \\
\cline { 2 - 4 } \multicolumn{1}{c}{$\begin{array}{c}\text { Ground } \\
\text { water }\end{array}$} & $\begin{array}{c}\text { Surface } \\
\text { water }\end{array}$ & Total \\
\hline Yalobusha & 0 & 0 & 0 \\
Yazoo & 16.56 & 0 & 16.56 \\
Total & 146.47 & 126.10 & 272.57 \\
\hline
\end{tabular}




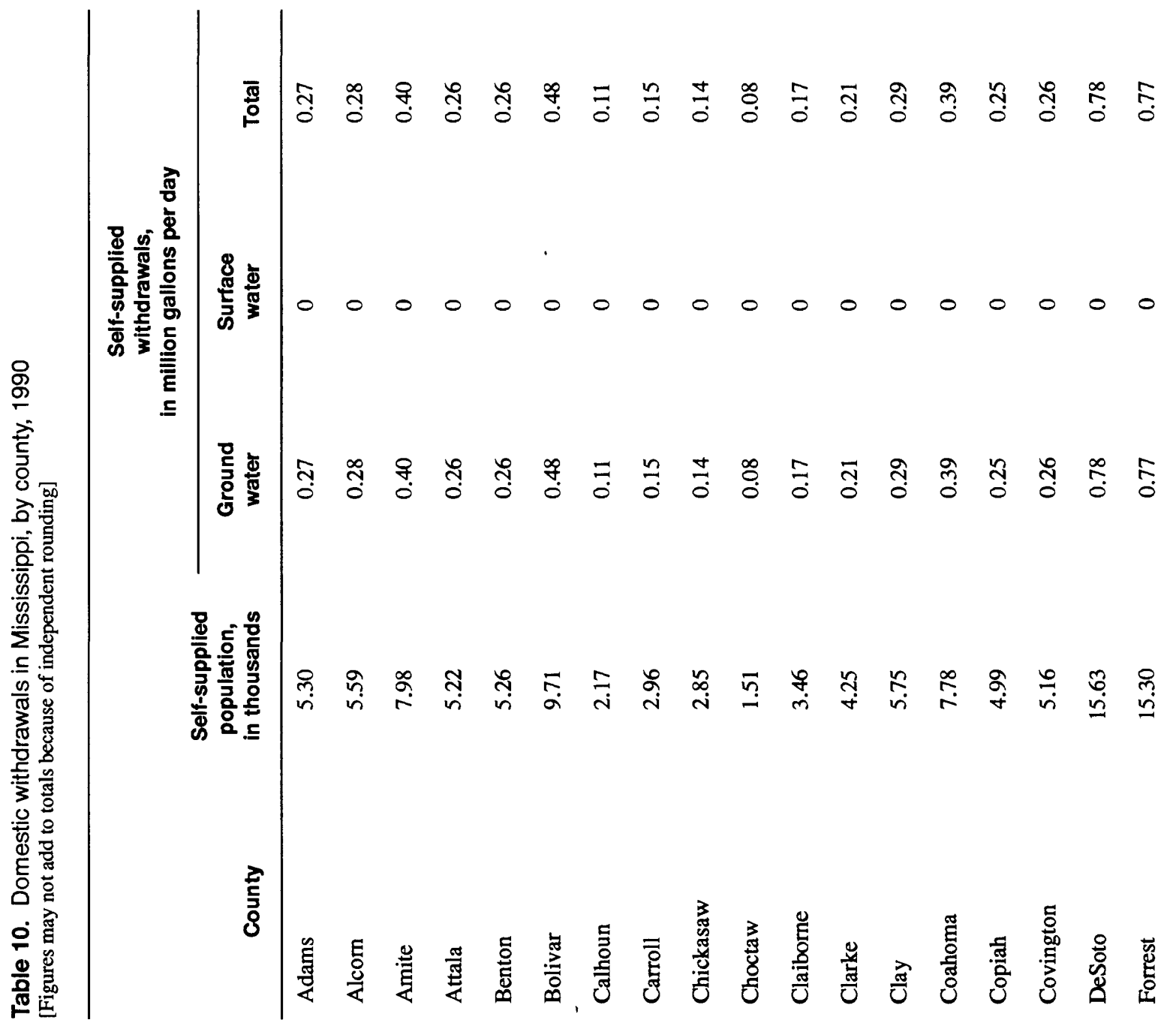




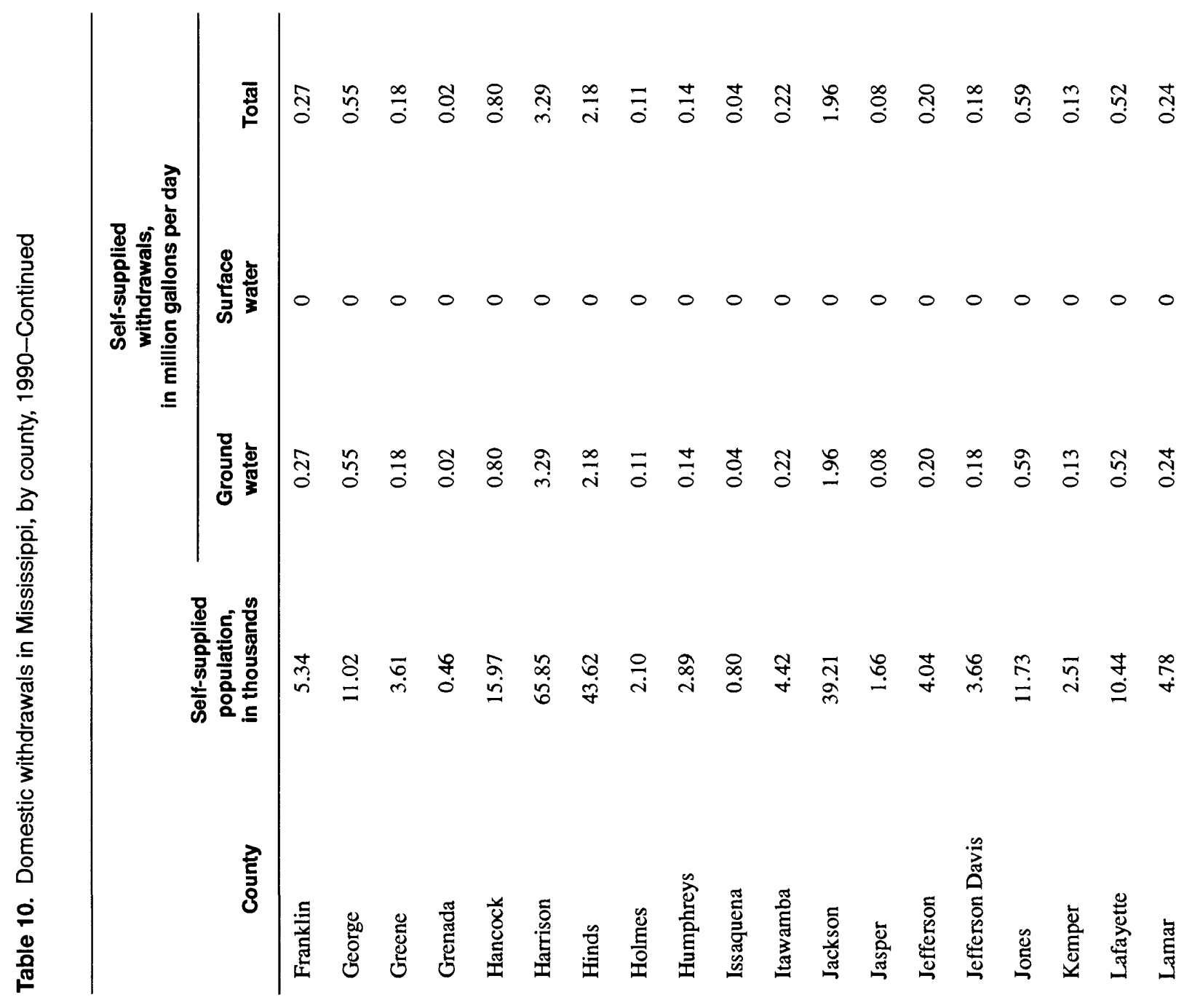




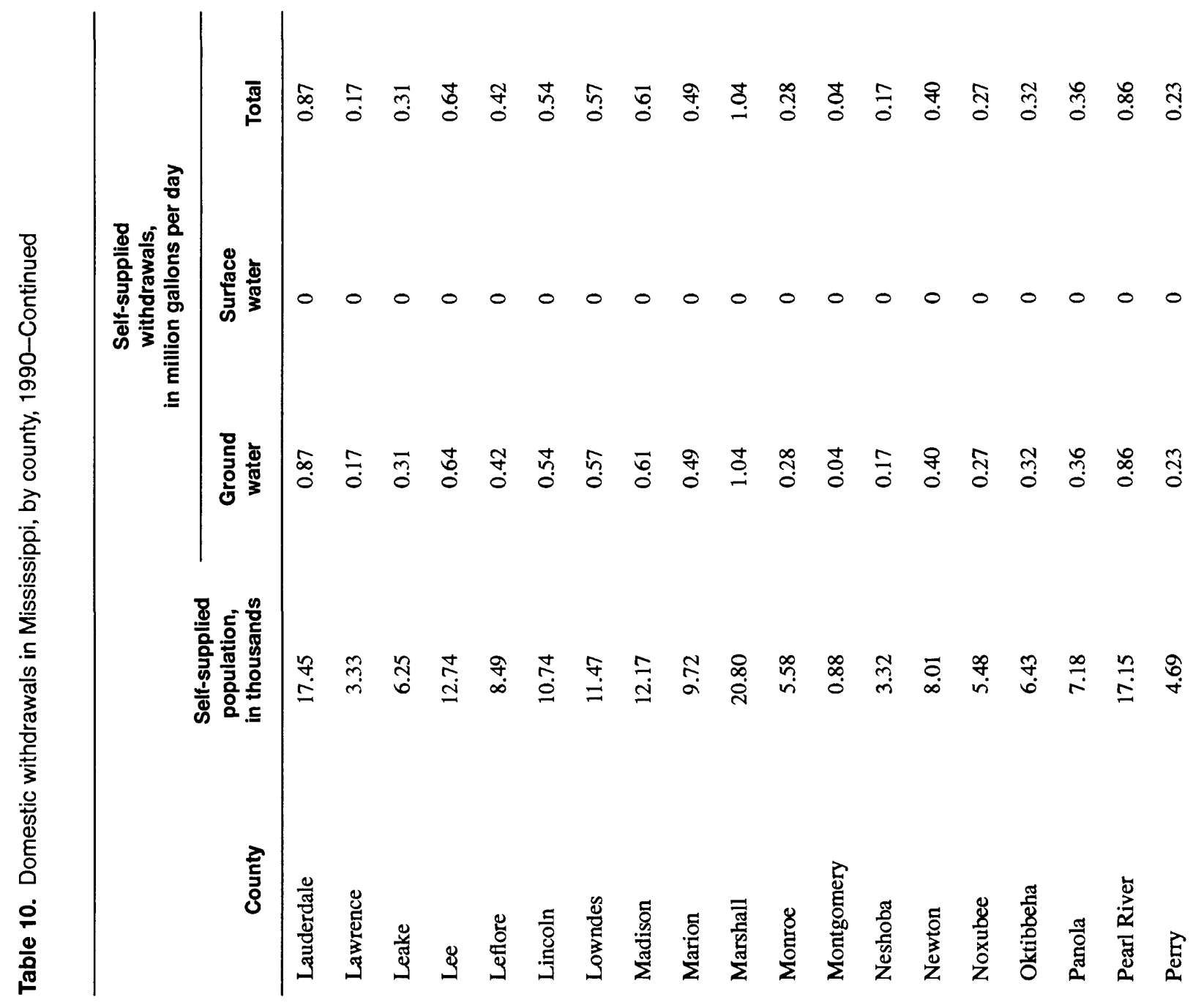




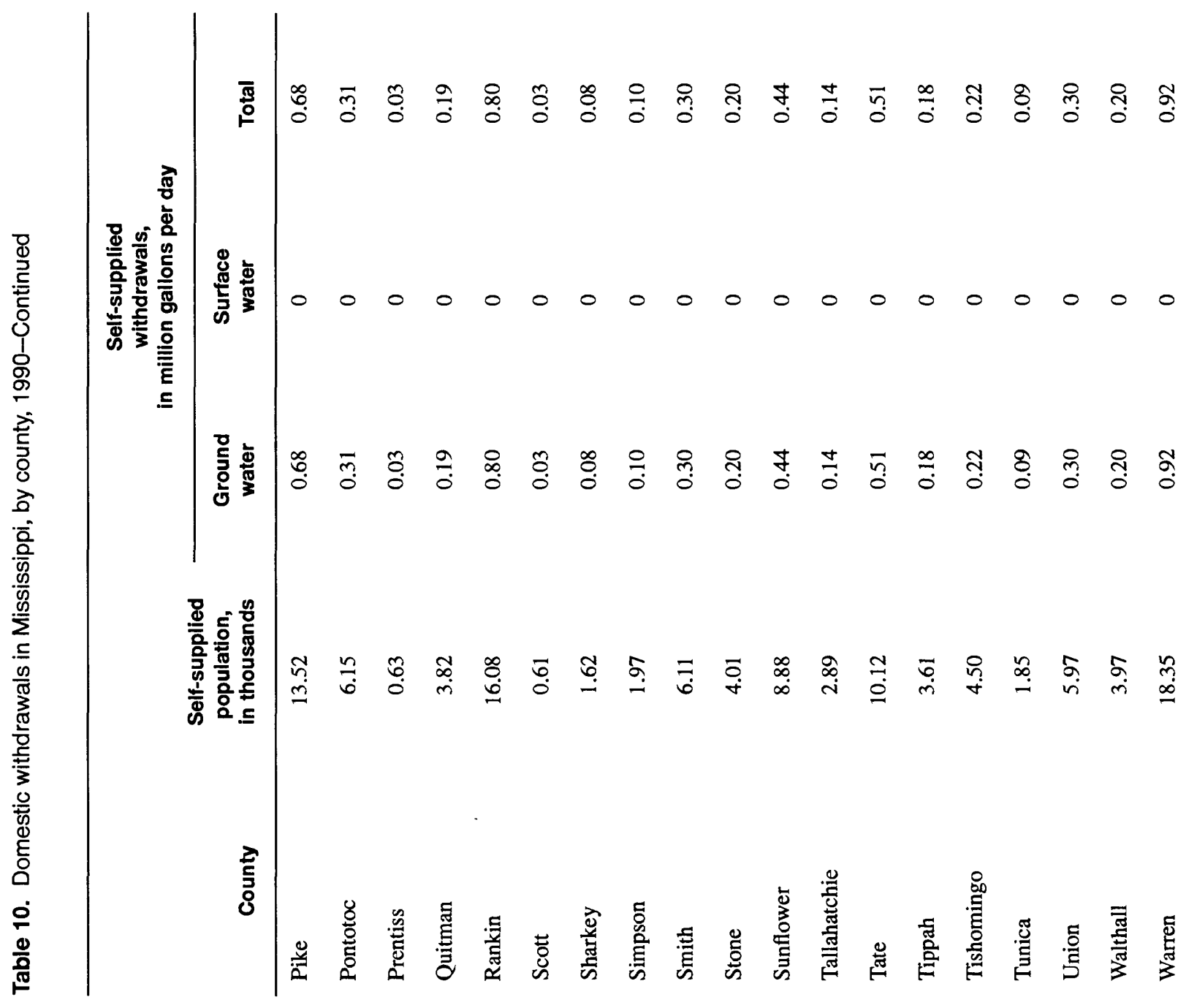




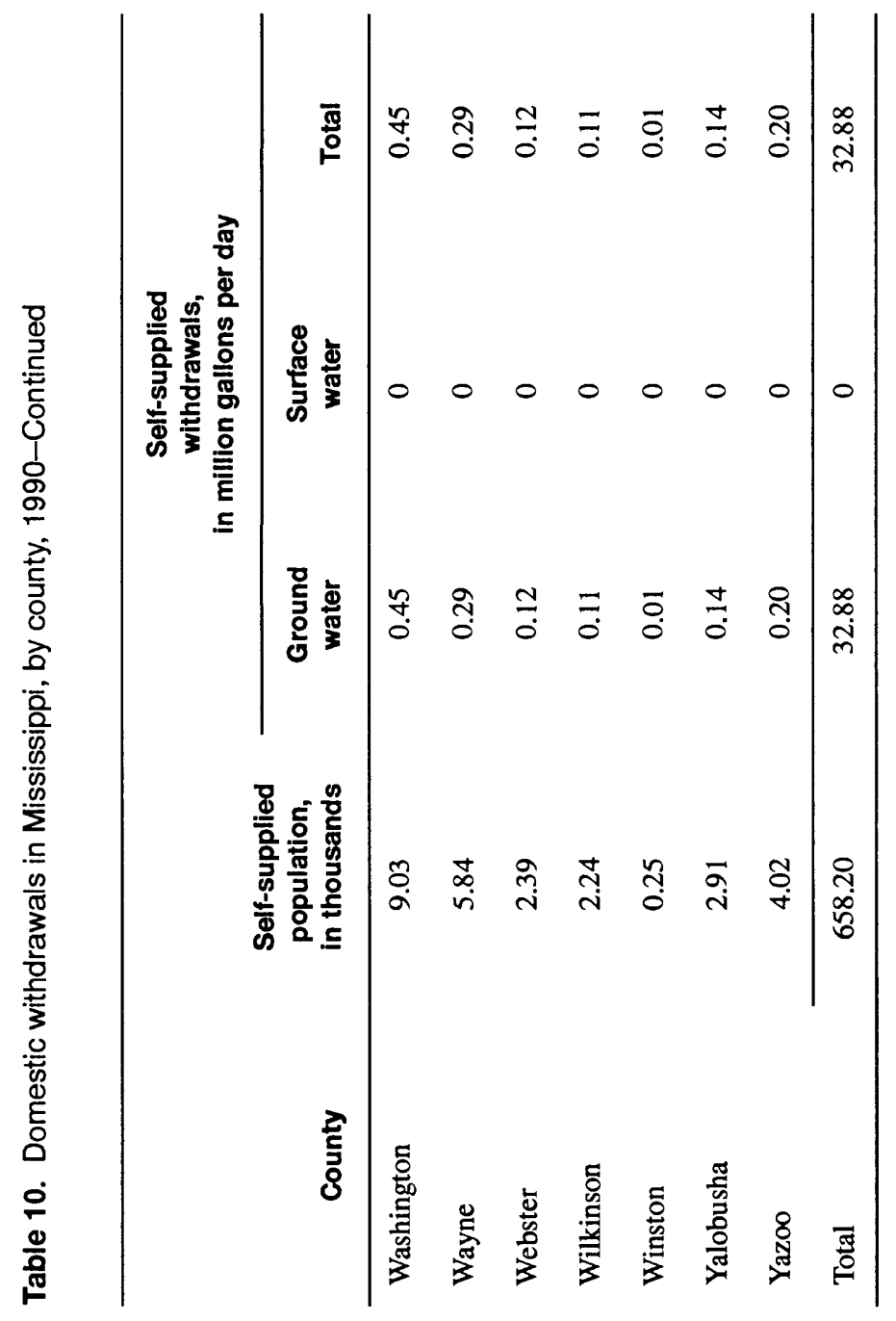


Table 11. Commercial withdrawals in Mississippi, by county, 1990

[Figures may not add to totals because of independent rounding]

\begin{tabular}{|c|c|c|c|}
\hline \multirow[b]{2}{*}{ County } & \multicolumn{3}{|c|}{$\begin{array}{c}\text { Withdrawals, } \\
\text { In million gallons per day }\end{array}$} \\
\hline & $\begin{array}{l}\text { Ground } \\
\text { water }\end{array}$ & $\begin{array}{l}\text { Surface } \\
\text { water }\end{array}$ & Total \\
\hline Adams & 0 & 0 & 0 \\
\hline Alcorn & 0 & 0 & 0 \\
\hline Amite & 0 & 0 & 0 \\
\hline Attala & 0 & 0 & 0 \\
\hline Benton & 0 & 0 & 0 \\
\hline Bolivar & 0.90 & 0 & 0.90 \\
\hline Calhoun & 0 & 0 & 0 \\
\hline Carroll & 0 & 0 & 0 \\
\hline Chickasaw & 0 & 0 & 0 \\
\hline Choctaw & 0 & 0 & 0 \\
\hline Claiborne & 0.17 & 0 & 0.17 \\
\hline Clarke & 0 & 0 & 0 \\
\hline Clay & 0 & 0 & 0 \\
\hline Coahoma & 0.24 & 0 & 0.24 \\
\hline Copiah & 0 & 0 & 0 \\
\hline Covington & 0.64 & 0 & 0.64 \\
\hline DeSoto & 0 & 0 & 0 \\
\hline Forrest & 2.11 & 0 & 2.11 \\
\hline Franklin & 0 & 0 & 0 \\
\hline George & 0 & 0 & 0 \\
\hline Greene & 0 & 0 & 0 \\
\hline Grenada & 0 & 0 & 0 \\
\hline Hancock & 1.70 & 0 & 1.70 \\
\hline Harrison & 0.44 & 0 & 0.44 \\
\hline Hinds & 0.98 & 0 & 0.98 \\
\hline Holmes & 0. & 0 & 0 \\
\hline Humphreys & 0.02 & 0 & 0.02 \\
\hline Issaquena & 0 & 0 & 0 \\
\hline
\end{tabular}


Table 11. Commercial withdrawals in Mississippi, by county, 1990-Continued

\begin{tabular}{|c|c|c|c|}
\hline \multirow[b]{2}{*}{ County } & \multicolumn{3}{|c|}{$\begin{array}{c}\text { Withdrawals, } \\
\text { in mililion galions per day }\end{array}$} \\
\hline & $\begin{array}{l}\text { Ground } \\
\text { water }\end{array}$ & $\begin{array}{c}\text { Surface } \\
\text { water }\end{array}$ & Total \\
\hline Itawamba & 0 & 0 & 0 \\
\hline Jackson & 0.23 & 0 & 0.23 \\
\hline Jasper & 0 & 0 & 0 \\
\hline Jefferson & 0.01 & 0 & 0.01 \\
\hline Jefferson Davis & 0 & 0 & 0 \\
\hline Jones & 0.32 & 0 & 0.32 \\
\hline Kemper & 0 & 0 & 0 \\
\hline Lafayette & 0.82 & 0 & 0.82 \\
\hline Lamar & 0.06 & 0 & 0.06 \\
\hline Lauderdale & 0.50 & 0 & 0.50 \\
\hline Lawrence & 0 & 0 & 0 \\
\hline Leake & 0 & 0 & 0 \\
\hline Lee & 0 & 0 & 0 \\
\hline Leflore & 0.60 & 0 & 0.60 \\
\hline Lincoln & 0 & 0 & 0 \\
\hline Lowndes & 0.84 & 0 & 0.84 \\
\hline Madison & 0.08 & 0 & 0.08 \\
\hline Marion & 0 & 0 & 0 \\
\hline Marshall & 0 & 0 & 0 \\
\hline Monroe & 0.01 & 0 & 0.01 \\
\hline Montgomery & 0 & 0 & 0 \\
\hline Neshoba & 0 & 0 & 0 \\
\hline Newton & 0 & 0 & 0 \\
\hline Noxubee & 0 & 0 & 0 \\
\hline Oktibbeha & 2.03 & 0 & 2.03 \\
\hline Panola & 0 & 0 & 0 \\
\hline Pearl River & 0.01 & 0 & 0.01 \\
\hline Perry & 0 & 0 & 0 \\
\hline Pike & 0.26 & 0 & 0.26 \\
\hline
\end{tabular}


Table 11. Commercial withdrawals in Mississippi, by county, 1990-Continued

\begin{tabular}{|c|c|c|c|}
\hline \multirow[b]{2}{*}{ County } & \multicolumn{3}{|c|}{$\begin{array}{c}\text { W/thdrawals, } \\
\text { In milllon gallons per day }\end{array}$} \\
\hline & $\begin{array}{l}\text { Ground } \\
\text { water }\end{array}$ & $\begin{array}{l}\text { Surface } \\
\text { water }\end{array}$ & Total \\
\hline Pontotoc & 0 & 0 & 0 \\
\hline Prentiss & 0 & 0 & 0 \\
\hline Quitman & 0 & 0 & 0 \\
\hline Rankin & 0.79 & 0 & 0.79 \\
\hline Scott & 0 & 0 & 0 \\
\hline Sharkey & 0.03 & 0 & 0.03 \\
\hline Simpson & 0.20 & 0 & 0.20 \\
\hline Smith & 0 & 0 & 0 \\
\hline Stone & 0.58 & 0 & 0.58 \\
\hline Sunflower & 0.27 & 0 & 0.27 \\
\hline Tallahatchie & 0 & 0 & 0 \\
\hline Tate & 0 & 0 & 0 \\
\hline Tippah & 0.10 & 0 & 0.10 \\
\hline Tishomingo & 0 & 0 & 0 \\
\hline Tunica & 0 & 0 & 0 \\
\hline Union & 0.03 & 0 & 0.03 \\
\hline Walthall & 0.39 & 0 & 0.39 \\
\hline Warren & 0 & 0 & 0 \\
\hline Washington & 0.12 & 0 & 0.12 \\
\hline Wayne & 0.06 & 0 & 0.06 \\
\hline Webster & 0 & 0 & 0 \\
\hline Wilkinson & 0 & 0 & 0 \\
\hline Winston & 0 & 0 & 0 \\
\hline Yalobusha & 0 & 0 & 0 \\
\hline Yazoo & 0 & 0 & 0 \\
\hline Total & 15.54 & 0 & 15.54 \\
\hline
\end{tabular}




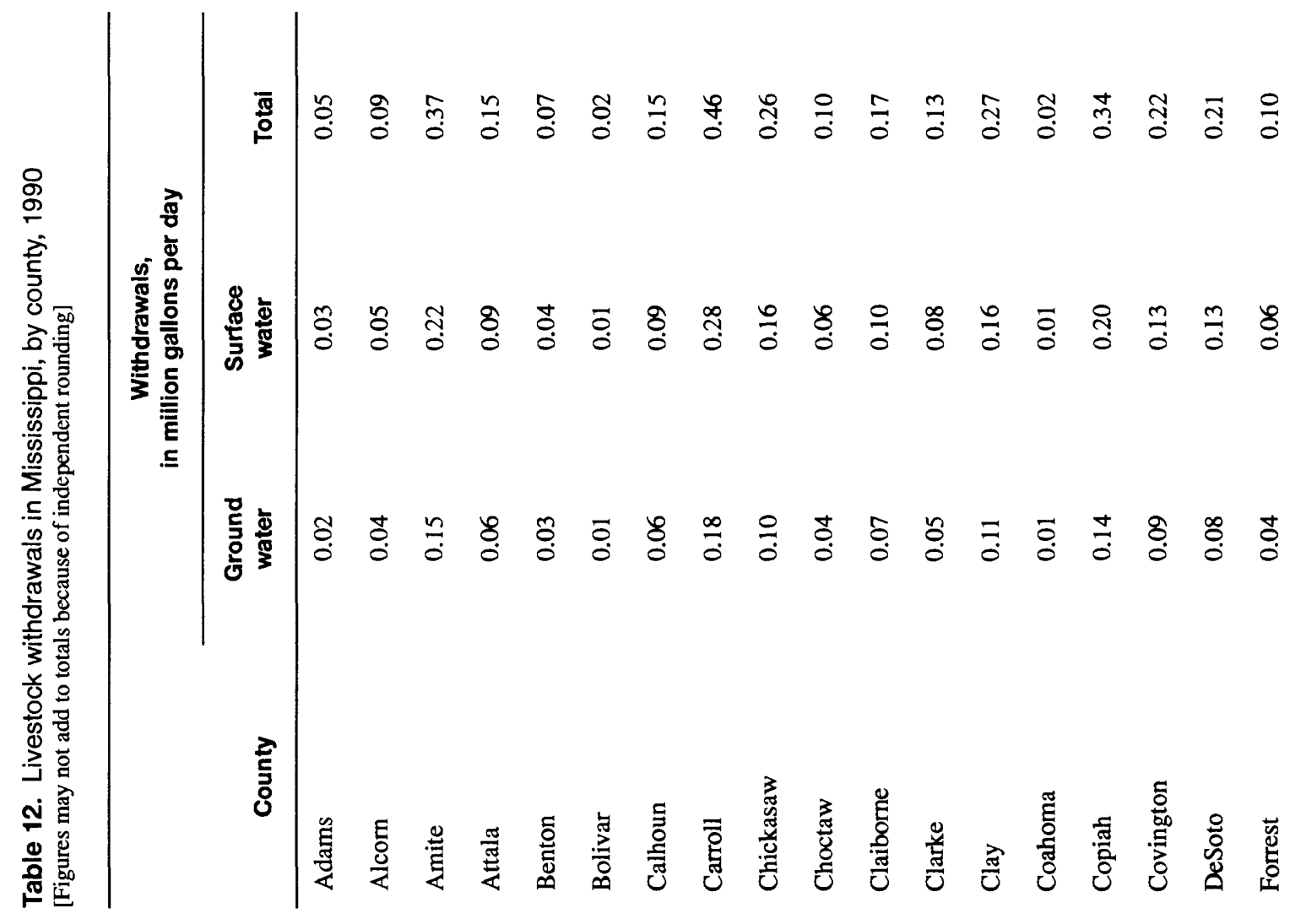




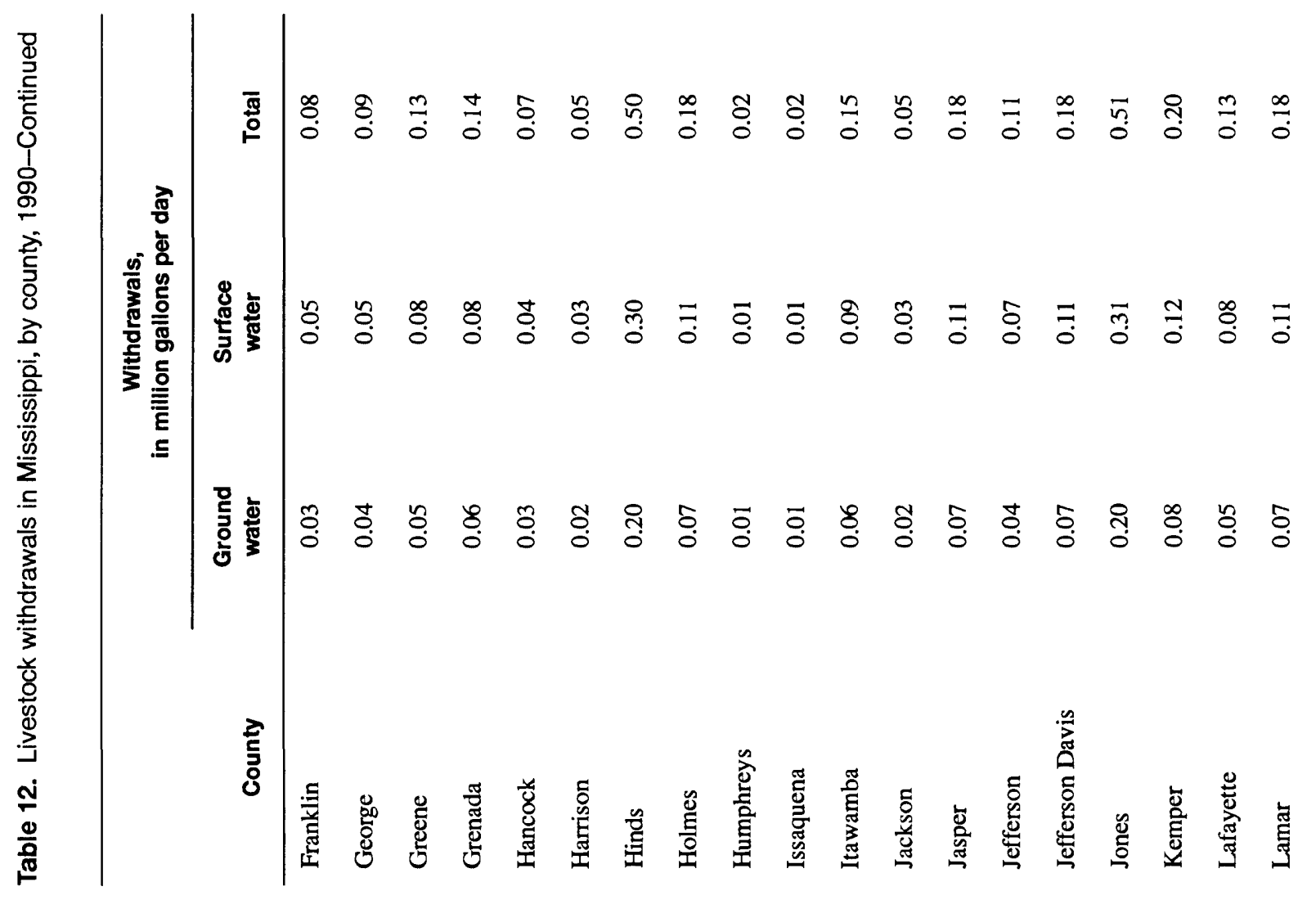




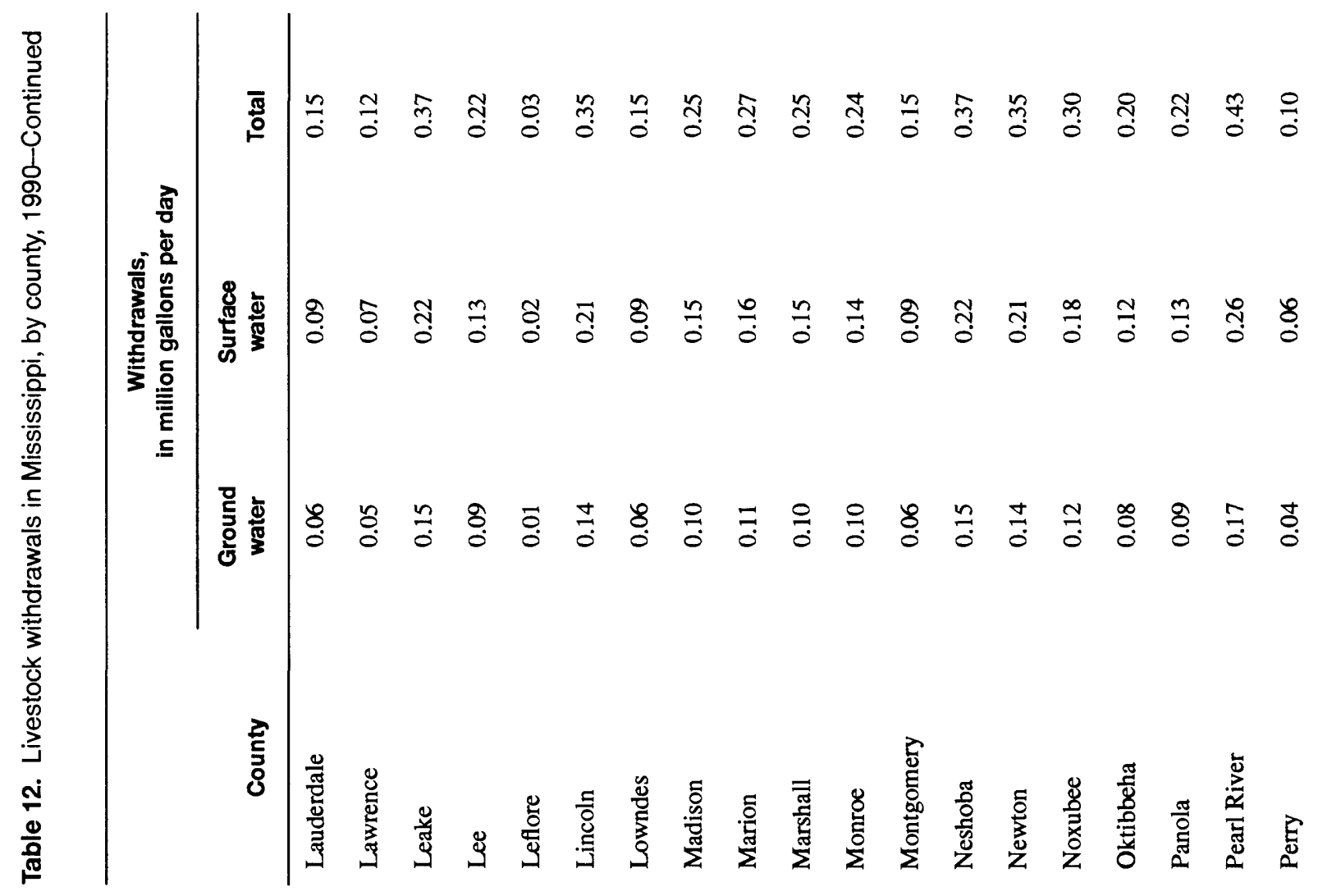




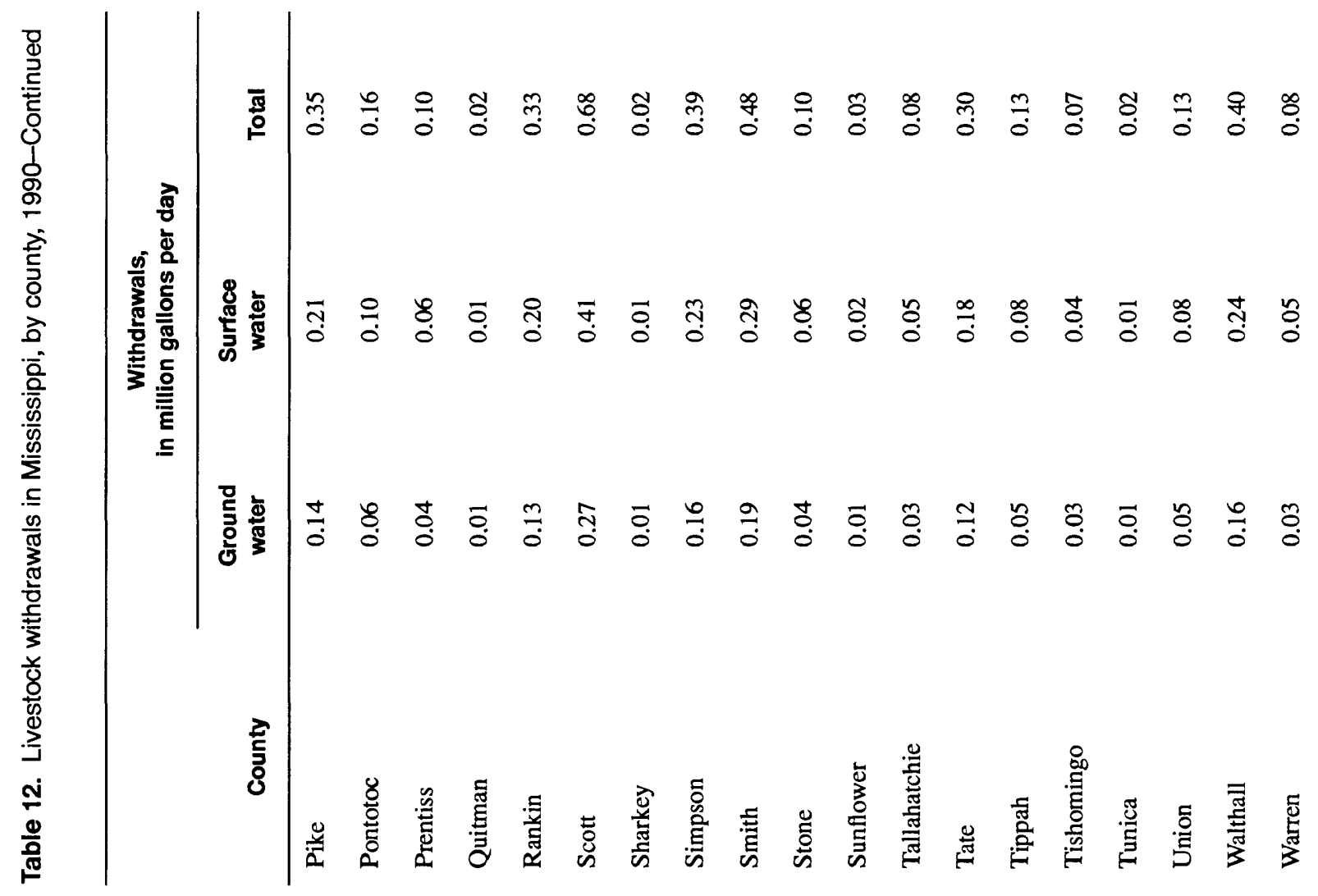




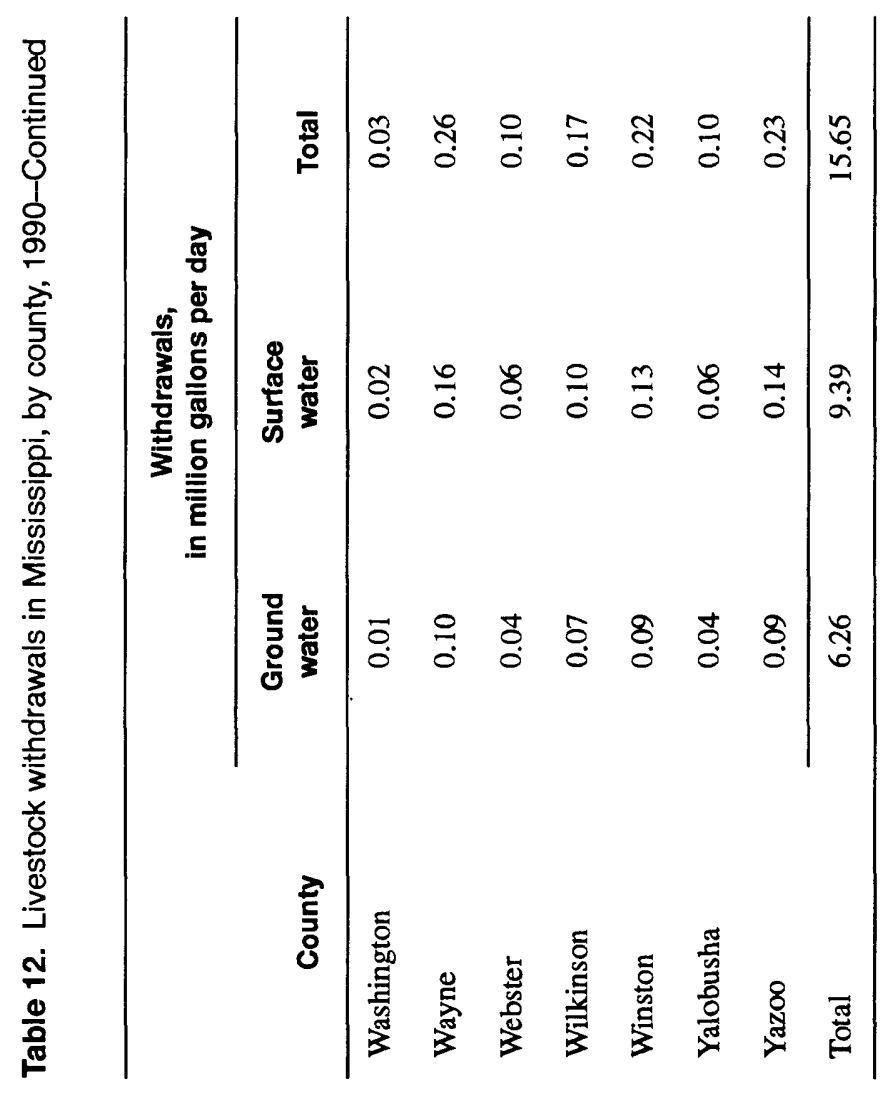

